\begin{abstract}
We find that the number of independent directors on corporate boards increases by approximately $24 \%$ following financial covenant violations in credit agreements. Most of these new directors have links to creditors. Firms that appoint new directors after violations are more likely to issue new equity, and to decrease payout, operational risk and CEO cash compensation than firms without such appointments. We conclude that a firm's board composition, governance, and policies are shaped by current and past credit agreements.
\end{abstract}

Keywords: Corporate boards, Corporate governance, Covenant violations

JEL Classifications: G21, G32, G33, G34

Daniel Ferreira

Professor of Finance

London School of Economics - Department of Finance

Houghton Street

London, WC2A 2AE, United Kingdom

phone: +44 2079557544

e-mail: d.ferreira@Ise.ac.uk

Miguel A. Ferreira*

Banco BPI Professor of Finance

Nova School of Business and Economics

Campus de Campolide

Lisbon, 1099-032, Portugal

phone: +351213801631

e-mail: miguel.ferreira@novasbe.pt

Beatriz Mariano

Lecturer in Banking

Cass Business School

106 Bunhill Row

London, EC1Y 8TZ, United Kingdom

phone: +44 2070400448

e-mail: Beatriz.Mariano@city.ac.uk

${ }^{*}$ Corresponding Author 


\title{
Creditor Control Rights and Board Independence*
}

\author{
Daniel Ferreira $^{\dagger} \quad$ Miguel A. Ferreira ${ }^{\ddagger} \quad$ Beatriz Mariano $^{\S}$
}

June 14, 2017

\begin{abstract}
We find that the number of independent directors on corporate boards increases by approximately $24 \%$ following financial covenant violations in credit agreements. Most of these new directors have links to creditors. Firms that appoint new directors after violations are more likely to issue new equity, and to decrease payout, operational risk and CEO cash compensation than firms without such appointments. We conclude that a firm's board composition, governance, and policies are shaped by current and past credit agreements.
\end{abstract}

JEL classification: G21, G32, G33, G34

Keywords: Corporate boards, Corporate governance, Covenant violations

${ }^{*}$ We thank Andres Almazan, Per Axelson, Ilona Babenko, Laurent Bach, Tom Bates, Daniel Carvalho, Geraldo Cerqueiro, Jonathan Cohn, Andrew Ellul, Cesare Fracassi, Diego Garcia, Jarrad Harford, Jay Hartzell, Thomas Hellmann, Leonid Kogan, Yrjo Koskinen, Kai Li, Chen Lin, Laura Lindsey, Daniel Metzger, Walter Novaes, Daniel Paravisini, Enrico Perotti, Alessio Saretto, Clemens Sialm, Stephan Siegel, Laura Starks, and Margarita Tsoutsoura; participants at the European Finance Association Annual Meeting and University of British Columbia Winter Finance Conference; and seminar participants at Arizona State University, EIEF, ESCP, IE Business School, Hong Kong University of Science and Technology, London School of Economics, Nanyang Technological University, National University of Singapore, PUC-Rio, Queen Mary University, Singapore Management University, University of British Columbia, University of Cambridge, University of New South Wales, Universitat Pompeu Fabra, University of Technology-Sidney, University of Texas-Austin, and University of Sydney for helpful comments. Financial support from the European Research Council is gratefully acknowledged.

${ }^{\dagger}$ London School of Economics, CEPR and ECGI. E-mail: D.Ferreira@lse.ac.uk.

${ }^{\ddagger}$ Nova School of Business and Economics, CEPR and ECGI. E-mail: miguel.ferreira@novasbe.pt.

$\S$ Cass Business School. E-mail: Beatriz.Mariano@city.ac.uk. 
After a loan covenant violation, creditors can use the threat of accelerating loan payments and/or terminating credit agreements to extract concessions from borrowers in exchange for contract renegotiation. In practice, creditors rarely need to carry out such threats; most covenant violations lead to contract renegotiation (Roberts (2015)). Covenant violations enhance creditors' bargaining position in renegotiations, as shown by the empirical literature on the impact of violations on firm policies (e.g., Chava and Roberts (2008), Roberts and Sufi (2009), Nini, Smith, and Sufi (2009, 2012), and Falato and Liang (2016)). This literature describes such an improvement in creditors' bargaining power as an increase in "creditor control rights."

In this paper, we show that covenant violations trigger changes that have profound effects on a firm's governance. Such governance changes in turn magnify the effect of loan covenants on firm policies, particularly those policies that require the board to behave proactively. By changing governance, covenant violations can thus have an effect on firm policies many years after the event, implying that current and past credit agreements have a long-lasting impact on a firm's governance.

Our main finding is that firms tend to appoint new independent directors to their boards following covenant violations. The new directors are typically not replacements for outgoing directors, implying that board size increases as new directors are appointed. We call the event of a covenant breach an implied covenant violation, because a violation may not have occurred as a consequence of covenant waivers obtained through renegotiations. We retain such cases because renegotiation is one of the mechanisms through which loan covenants can affect firm choices. The effect of implied covenant violations on the number of independent directors is sizable: Our baseline specification indicates that a violation leads to a $24 \%$ increase in the number of independent directors. Our analysis supports the hypothesis that covenant violations lead to changes in board composition.

Our work is related to a number of studies that focus on the impact of creditors and credit agreements on corporate governance. Gilson (1990) was the first to investigate the influence of creditors on board composition. He finds evidence that, in negotiated restructurings, banks influence the appointment of directors both directly and through share ownership. Kaplan

\footnotetext{
${ }^{1}$ The term control rights is used informally; a creditor has no legal rights to control the borrower following a covenant violation.
} 
and Minton (1994) find that poor financial performance triggers the appointment of former bank directors to the boards of Japanese firms, which indicates that banks actively influence corporate governance. Anderson, Mansi, and Reeb (2004) find a negative association between board independence and the cost of debt, as the presence of independent directors improves the quality of financial accounting reports. Kroszner and Strahan (2001) and Guner, Malmendier, and Tate (2008) study the costs and benefits of the presence of bankers on boards and find evidence of conflicts of interest between creditors and shareholders. In this paper, we show that credit agreements affect board appointments outside bankruptcy, and we provide a causal estimate of the effect of implied covenant violations on board composition.

Nini, Smith, and Sufi (2012) show that CEO turnover increases after covenant violations. Our evidence complements theirs, as we show that the turnover of independent directors is also a governance mechanism that is available to creditors. However, our evidence is of a different nature, as we show that the effect of covenant violations on board composition is stronger for the subset of firms that do not replace their CEOs after a covenant violation. Becker and Stromberg (2012) show that a 1991 change in the law that required boards to consider the interests of creditors in financially distressed firms led to an increase in leverage among affected firms and a reduction in the use of covenants. Their evidence suggests that, as boards become more likely to consider the interests of creditors, covenants become less important. Our findings are broadly consistent with this hypothesis.

The finding that loan covenant violations lead to the appointment of new directors to the board raises a number of questions: Who are these directors? Are they related to creditors? If so, how are they related? We show that post-violation directors are similar to ordinary directors in all but one respect: Directors appointed following covenant violations are much more likely to hold positions in other firms that borrow from the same banks.

What do these new directors do? We find that firms that appoint new directors after covenant violations are more likely to change certain firm policies that require board initiative. Such firms are more likely to raise new equity through seasoned equity offerings (SEOs) and invest than firms that violate covenants but do not change their boards, which suggest that reformed boards are in a better position to address debt overhang problems. In addition, reformed boards appear to take actions that decrease payout and operational risk, which alleviate 
concerns about risk-shifting problems. We also find that the structure of CEO compensation changes after violations. After violations, but without changes to the board, CEOs experience an increase in cash bonuses that roughly compensates them for a reduction in the value of equity-based compensation. However, this trend is reversed in firms that appoint new independent directors after violations: Cash bonuses fall and equity-based pay increases more than in firms without such appointments.

To summarize, we find that new directors are more likely to have links to creditors and that reformed boards are more likely to adopt creditor-friendly policies. We also show that firms with stronger lending relationships with their creditors appoint more directors in response to violations than firms without such relationships. The evidence, however, does not settle the question of whether creditors explicitly intervene in corporate governance issues. It is true that creditors trigger the process that leads to board changes by declaring a covenant in breach. However, the process that follows could largely be in the hands of the management or large shareholders who push for changes in board composition. For example, it could be that, to improve its negotiation stance, a firm chooses to hire a director who has experience in dealing with a particular bank.

The reasons for creditors to care about board composition are not obvious. Even if creditors can influence board appointments, directors still owe fiduciary duties to shareholders.2 $2^{2}$ In addition, explicit intervention by creditors may force them to owe fiduciary duties to shareholders or, in the case of bankruptcy, make them subject to equitable subordination (i.e., courts may treat their claims as subordinate on equitable grounds). Thus, debt contracts typically do not give creditors explicit rights over board appointments. However, this does not mean that creditors abstain from corporate governance activism. There is ample anecdotal evidence of lenders demanding changes to board composition as a consequence of credit renegotiations $3^{3}$

\footnotetext{
${ }^{2}$ However, depending on the company's charter and state corporate law, a director may also owe fiduciary duties to other stakeholders, such as creditors, employees, customers and the community. For example, in Delaware, directors also owe fiduciary duties to creditors in the vicinity of insolvency (see Becker and Stromberg (2012)).

${ }^{3}$ For example, a forbearance agreement between BMO Harris Bank and Quadrant 4 System Corporation required that "the Company appoint(ed) three new directors who were acceptable to the Board and to BMO." Similarly, after failing to comply with its financial covenants and other contractual obligations, RCS Capital Corporation entered an agreement with its lenders, which required "the appointment of an independent director reasonably acceptable to such lenders." See the Internet Appendix for more details on these and other examples.
} 
There are also cases in which a contract renegotiation triggered by a covenant violation is reported alongside the appointment of new independent directors, although no explicit link is mentioned $4^{4}$ Baird and Rasmussen (2006) and Nini, Smith, and Sufi (2012) argue that creditors' influence on corporate governance is often subtle and exercised behind the scenes, which makes the empirical documentation of their activities challenging.

Our paper makes several contributions to the literature. Our results are complementary to the literature on the effect of loan covenant violations on firm outcomes (Chava and Roberts (2008), Roberts and Sufi (2009), Nini, Smith, and Sufi (2009, 2012), and Falato and Liang (2016)). Our work shows that credit agreements have long-lasting effects on how firm decisions are made. Board composition is a means to an end; new directors can influence firm decisions for many years after their initial appointment.

Our findings also provide direct evidence of the empirical relevance of models of contingent allocation of control rights (e.g., Aghion and Bolton (1992) and Dewatripont and Tirole (1994)). In these models, creditors acquire enhanced control rights in low cash flow states. Our evidence shows that a consequence of such a change in control rights is the appointment of new "monitors" to the board. The evidence thus suggests that enhanced creditor control rights strengthen the monitoring role of the board.

We also contribute to the board of directors literature. Although the endogenous nature of boards is often acknowledged (e.g., Hermalin and Weisbach (1998)), the literature has been unable to provide credible causal estimates of the effect of firm characteristics on board structure. It has also been difficult to identify firm-level variables that have an economically (rather than only statistically) significant effect on board composition (see Ferreira, Ferreira, and Raposo (2011)). In addition, our results help to explain the observed positive relationship between leverage and board independence (Boone, Casares Field, Karpoff, and Raheja (2007), Coles, Daniel, and Naveen (2008), and Linck, Netter, and Yang (2008)). Our evidence shows that leverage can directly affect both board independence and size: Highly leveraged firms are more likely to violate covenants, which may lead to the appointment of new independent directors.

\footnotetext{
${ }^{4}$ See, for example, the case of Hooper Holmes in the Internet Appendix.
} 


\section{Data}

We construct our sample from the non-financial firms in the Investor Responsibility Research Center (IRRC) database, from which we obtain board data. We complement the IRRC data with data on director characteristics from BoardEx. We obtain accounting and segment data from Compustat and stock returns from CRSP. CEO compensation and tenure data are from ExecuComp.

We obtain data on syndicated loans from the DealScan database. We restrict the sample to loans with information on maturity and spread over the LIBOR (all-in spread drawn), and we eliminate firms with loans for which we do not have any covenant information or that do not include a covenant on the current ratio, net worth, tangible net worth, or debt-to-EBITDA ratio.

Our main sample uses accounting data from 1994 to 2006 and board data from 1996 to 2008 to allow for lags in our specifications. Data availability determines the beginning of the sample period; before 1996, there are no IRRC board data. The sample period is determined by economic considerations. First, we do not include the period of the recent financial crisis, which led to major changes in bank behavior and regulation, credit market conditions, and the financial performance of borrowers. Second, until 2006, "covenant-light contracts" were virtually non-existent, while since 2007, and especially in more recent years, they have rapidly become common, with nearly $40 \%$ of all new loans being covenant-light (Becker and Ivashina (2016)). Covenant-light contracts normally have the same number of covenants as covenantheavy contracts but weaker enforcement. The wide use of covenant-light contracts is thus likely to attenuate the effect of violations on firm policies. Although our baseline sample includes only data from 1994 to 2008, the Internet Appendix reports all of our main tests for an extended sample covering the 1994-2014 period.

For each loan, we first obtain covenant thresholds on the current ratio, net worth, tangible net worth, and debt-to-EBITDA ratio. We assume that the firm is bound by the covenants in every quarter until maturity. Since a firm might have more than one active loan in a given quarter, we use the minimum threshold (or the maximum for the debt-to-EBITDA ratio) for each covenant across all active loans in a given quarter. We use Compustat data at a quarterly 
frequency to compute the accounting variables. If the accounting variable is equal to or below the threshold, there is an implied covenant violation. In the case of the debt-to-EBITDA covenant, an implied covenant violation occurs if the accounting variable is equal to or above the threshold.

Since some of the relevant accounting variables are ratios and others are measured in dollars, we measure the distance to the covenant threshold as a proportion of the threshold. We call the minimum distance to the threshold across the four covenants the binding distance, which is defined as follows:

$$
\begin{aligned}
D_{i t} & \equiv \min _{j, k} \tilde{D}_{i t j k}, \text { where } \\
\tilde{D}_{i t j k} & \equiv \min _{z} \frac{C_{i t j k}-T_{i t j k z}}{T_{i t j k z}},
\end{aligned}
$$

where $i$ and $t$ denote firm and year, respectively; $j=1, \ldots, 4$ denotes a quarter of year $t$; $k=1, \ldots, 4$ denotes covenant type (one of the four covenant types); $z$ denotes an active loan (a firm may have more than one loan with covenants); $C_{i t j k}$ is the quarterly value of the accounting variable relevant for covenant $k$; and $T_{i t j k z}$ is the threshold for active loan $z$, covenant type $k$, in quarter $j$ of year $t$ for firm $i$. Equation (1) applies strictly only to the current ratio, net worth, and tangible net worth covenants. For the debt-to-EBITDA covenant, $\tilde{D}_{i t j k}$ is defined analogously by $T_{i t j k z}-C_{i t j k}$. We also calculate an alternative measure of distance to thresholdcalled tightness - in which the denominator in equation (2) is the standard deviation of the accounting variable over the full sample period. We use this variable for additional tests later in the paper.

Equation (1) implies that an implied covenant violation event is a firm-year observation in which the firm breaches at least one covenant threshold in at least one quarter of the year. For expositional simplicity, we allow $D_{i t}$ to assume negative values; a firm-year observation that displays "negative distance" is an implied covenant violation event.5

Our final (baseline) sample covers 597 firms and 2,801 firm-year observations. For this

\footnotetext{
${ }^{5}$ Because EBITDA may assume values that are close to zero or even negative, the debt-to-EBITDA ratio becomes meaningless in such cases. Thus, we replace negative values with a debt-to-EBITDA ratio equal to its 99th percentile in the sample of positive EBITDA observations. The results show little sensitivity to how such cases are treated. In particular, the results are similar if all negative EBITDA observations are dropped.
} 
sample, we find that $51 \%$ of the firms have at least one covenant violation during the sample period (305 firms), and 24\% of the firm-year observations include a violation (675 firm-year observations) ${ }^{6}$ Because a covenant violation event requires a violation in only one quarter of the year, the number of observations in violation is mechanically inflated relative to studies that use quarterly data. At a quarterly frequency, only $16 \%$ of the observations in our sample are violation events.

As in Chava and Roberts (2008) and Falato and Liang (2016), we infer violations from threshold and accounting data. This procedure may lead to coding and other errors, as well as possible overstatement of the actual number of violations because we do not consider covenant threshold renegotiations. Roberts (2015) shows that credit agreements are renegotiated on average every nine months, often outside violation events. Denis and Wang (2014) show that covenant thresholds are often renegotiated when firms are close to the threshold. In their sample, approximately $50 \%$ of contracts would be in violation if the original covenants had not been relaxed. Their results suggest that creditors gain more influence when a firm is close enough to a covenant threshold that, without renegotiation, the firm would almost certainly trigger the covenant. We may also misstate the number of actual violations because banks may waive covenants and because the accounting numbers, such as earnings-based measures and net worth, used in credit agreements may differ from those reported on financial statements. In sum, there are a number of possible sources of measurement errors, although we see no a priori reason to suspect that such errors would bias the results toward finding a positive effect of covenant violations on board independence.

The debt-to-EBITDA variable can be noisy, as it may vary across contracts depending on how debt is defined. Because debt-to-EBITDA is the most frequent covenant in our sample, we face a trade-off: Using this variable substantially increases the variation in the sample, but it also adds noise. As only few other papers use debt-to-EBITDA covenants (e.g., Demiroglu and James (2010), Denis and Wang (2014), Freudenberg, Imbierowicz, Saunders, and Steffen (2017)), we pay special attention to the construction of this variable. We read a sample of 50 credit agreement contracts of borrowers that experienced covenant violations in our sample.

\footnotetext{
${ }^{6}$ For comparison, Falato and Liang (2016), who also use data at an annual frequency, find that $21 \%$ of their firm-year observations include a violation event.
} 
The most common definition of debt is "total consolidated indebtedness," (e.g., consolidated gross debt). In only a few cases does debt exclude subordinated debt or is measured net of cash holdings. In Denis and Wang's (2014), total debt is also the most common definition of debt for contracts that establish a debt-to-EBITDA limit. We assume that total debt is equal to long-term debt plus debt in current liabilities. We measure EBITDA as net income minus extraordinary items, plus income taxes, interest expenses, and depreciation and amortization (over a test period equal to the four most recent fiscal quarters).

To minimize concerns about measurement errors, in Subsection 3.5, we consider an alternative definition of violations, which includes only covenant violations registered with the SEC. This definition has the advantage of eliminating many of the concerns above. There are, however, two disadvantages: We thereby obtain a severely reduced sample size, and we may miss many renegotiated violations. Our results, however, appear stronger when we consider only registered violations, which suggests that, if anything, measurement errors in our original definition of violations work against finding a positive effect of violations on board independence.

Table 1 presents descriptive statistics of each variable in our main sample. Table A.1 in the Appendix provides variable definitions and data sources. The median of the binding distance is 0.30 . The minimum and the maximum of the distance are quite extreme. For example, the minimum distance in the sample is -7.36 (more than seven times the threshold that triggers violation), which is one order of magnitude larger than the 10th percentile (-0.63). Even if these observations are not statistical outliers, it makes little economic sense to use them to estimate the effects of breaching a covenant threshold. Our empirical approach guarantees that such extreme values have no effect on our results, since we use (discontinuity) subsamples that exclude observations that are far from the threshold.

As our sample is constructed mainly by the intersection of three data sources (Compustat, IRRC, and DealScan), it is instructive to consider how the sample selection procedure affects the sample and the types of firms included in our study. Relative to studies that use covenant data from DealScan such as Chava and Roberts (2008), our sample is smaller for two reasons: the need to match data with the IRRC sample and the use of annual versus quarterly data. Table IA.1 in the Internet Appendix presents a comparison of the averages of each variable 
across data sources. $7^{7}$ This comparison reveals that firms in our sample are substantially larger than those in both the Compustat and the DealScan samples, which is expected because IRRC collects data for S\&P 1,500 companies only. Consistent with this fact, our sample has fewer covenant violations $(24 \%)$ than the DealScan sample (34\%). However, our sample firms are on average smaller than those in the IRRC sample. This is because larger firms are less likely to have syndicated loans with restrictive covenants 8 In contrast, sample selection has virtually no effect on average board characteristics. If anything, our sample has slightly smaller and more independent boards than the IRRC sample, but such differences are not meaningful 9

Table IA.2 in the Internet Appendix reports descriptive statistics for the value of the accounting variable $\left(C_{i t j k}\right)$, threshold $\left(T_{i t j k z}\right)$, binding distance $\left(\tilde{D}_{i t j k}\right)$, and tightness for each covenant type (at a quarterly frequency). The average current ratio is 2.04 , while the corresponding average threshold is significantly lower at 1.41. The average net worth and tangible net worth are significantly higher than their corresponding thresholds. The debt-to-EBITDA is the covenant with the lowest absolute distance to the threshold. The average debt-to-EBITDA is 3.20 , while the corresponding average threshold is only slightly higher at 3.49 . We conclude that, as expected, the average firm is not violating any covenant.

Table IA.3 in the Internet Appendix presents covenant tightness at loan origination and the number and frequency of violations for our sample (at a quarterly frequency), as well as comparable statistics for the sample in Chava and Roberts (2008). Our sample shows a lower fraction of observations with covenant violations than that of Chava and Roberts (2008). They report that $15 \%$ of their firm-quarter observations correspond to a violation of the current ratio covenant and $14 \%$ to a violation of the net worth (and tangible net worth) covenant, while we report $9 \%$ and $5 \%$, respectively. This is expected since our sample is smaller and contains

\footnotetext{
${ }^{7}$ As Compustat is the primary source for all accounting information, we define the restricted samples by their intersection with Compustat. Thus, the DealScan sample is defined as all observations in Compustat for which we could find data on covenants in the DealScan database. Similarly, the IRRC sample contains all firm-year observations for which data are available in both Compustat and IRRC.

${ }^{8}$ Despite the restriction imposed by the IRRC data, our firms are not substantially larger on average ( $\$ 3.5$ billion in assets) than those in other studies using loan covenant data, such as Nini, Smith, and Sufi (2009) (\$3.3 billion) and Denis and Wang (2014) (\$2.8 billion).

${ }^{9}$ To qualify as independent, a director must not be an employee, a former executive, or a relative of a current corporate executive of the company. In addition, the director must have no business relations with the company. The statistics for the board variables are also similar to those in other studies using IRRC data (e.g., Ferreira, Ferreira, and Raposo (2011)).
} 
larger firms on average due to the use of board data. Conditional on the presence of covenants, however, the covenant characteristics are similar. In Chava and Roberts's sample, the average values for covenant tightness at origination are 1.09 (current ratio) and 0.68 (net worth and tangible net worth), while in our sample the average values are 1.44 (current ratio), 0.58 (net worth), and 0.65 (tangible net worth).

\section{Methodology}

\subsection{Empirical Challenges}

Our goal is to estimate the average effect of an implied covenant violation on board composition, conditional on firms having loans with restrictive covenants. We start by clarifying our terminology. We define the "pure" (in the sense of "uncontaminated") effect of a violation as the effect that a violation would have while holding financial performance and other confounding factors constant. The main empirical challenge is to isolate the pure effect of a violation from the effect of financial performance and other confounding factors.

Following the previous literature (e.g., Chava and Roberts (2008), Roberts and Sufi (2009)), we call the pure effect of a covenant violation an increase in creditor control rights, where control rights refer to the informal power that creditors have over the firm in negotiations. Should negotiation break down after a violation, the creditor typically has the right to exercise the threat of terminating the credit agreement and requesting repayment of the loan. Controlling for financial performance and other factors, a violation can affect firm outcomes only because creditors have the right to make threats that were not possible before the violation. This does not mean that creditors actually use their enhanced control rights to obtain concessions from the firm. It could be that management or large shareholders encourage changes in policies in response to increased creditor control rights (i.e., in response to creditors' potential to make threats), even absent any indication that creditors favor a particular policy. We call creditors' actual use of explicit or implicit threats to obtain changes in policies creditor intervention. Thus, creditor control rights and creditor intervention are distinct concepts.

Our main goal is to show that an increase in creditor control rights caused by covenant 
violations leads to the appointment of new directors. While we do not provide direct evidence that creditor intervention leads to the appointment of new directors, our secondary goal is to analyze the mechanisms in greater detail.

To reduce firm heterogeneity around covenant thresholds, we focus primarily on results obtained in discontinuity subsamples constructed using narrow windows around the threshold. However, this approach is arguably not sufficient for addressing firm heterogeneity in our particular application. There are at least four challenges to apply a standard regression discontinuity design to our problem:

(1) Sample selection. The probability of firms exiting or entering a sample around the threshold may be correlated with board composition.

(2) Violations may directly affect the distance to threshold. After violations, if a firm takes actions that improve the underlying accounting variables, the firm may rapidly exit the violation sample, creating an unbalanced distribution of observations on either side of the threshold.

(3) The use of ratios as "running" variables. To understand this problem, consider, for example, the debt-to-EBITDA variable. Most of the variation in this variable comes from its denominator because earnings vary more than debt. Because debt-to-EBITDA is a convex function of EBITDA, for a given amount of variation in EBITDA, this ratio will vary more when it is initially low than when it is initially high. Thus, observations in violation of this covenant are likely to be farther from the threshold than observations that are not in violation. This mechanical effect means that any narrow window that is symmetric around the threshold is more likely to include observations that are not in violation than observations in violation.

(4) Covenant thresholds across firms. Although we normalize all covenant thresholds to make them comparable across firms, the underlying thresholds are different. Thus, the effects of violating a covenant might differ across firms because the breach of a tight covenant might have different implications from the breach of one that is not as tight. An additional issue arises because covenant thresholds are endogenously chosen (Gârleanu and Zwiebel (2009) and Demiroglu and James (2010)).

To address these concerns, we proceed as follows. First, we use firm fixed effects, which address the most obvious selection problems and time-invariant omitted variables. Second, we control for the distance to a violation threshold and for a long list of time-varying firm vari- 
ables, including measures of market and operating performance. Third, we perform balancing tests that show that observable firm characteristics are either similar on both sides or fully "explained" by the distance to threshold variable. Finally, if spurious correlations are created by omitted variables that may jump discontinuously, but not always exactly at the covenant thresholds, we would expect to find similar results for at least some thresholds that do not coincide with the actual threshold. To address this issue, we perform placebo tests aimed at detecting jumps in board independence at other points near the actual covenant thresholds.

\section{$2.2 \quad$ Empirical Model}

Our baseline specification is given by

$$
\ln y_{i t}=\beta v_{i t-2}+\sum_{p=1}^{P}\left[\gamma_{p 0}+\gamma_{p 1} v_{i t-2}\right] D_{i t-2}^{p}+\alpha_{t}+f_{i}+\boldsymbol{\delta} \mathbf{x}_{i t-2}^{\prime}+\varepsilon_{i t}
$$

where $y_{i t}$ is either the number of independent directors or the number of non-independent directors; $v_{i t}$ is an indicator variable that takes the value of one if firm $i$ breaches a covenant threshold in year $t$ (i.e., $v_{i t}=1$ if $\left.D_{i t} \leq 0\right) ; \sum_{p=1}^{P}\left[\gamma_{p 0}+\gamma_{p 1} v_{i t}\right] D_{i t}^{p}$ is a polynomial of order $P$ of the distance to threshold, where coefficients $\gamma_{p 0}$ and $\gamma_{p 1}$ can differ on the left- and right-hand sides of the threshold; $\alpha_{t}$ is a year fixed effect; $f_{i}$ is a firm fixed effect; and $\mathbf{x}_{i t}$ is a vector of control variables. Our default option is to cluster standard errors by firm; we obtain similar standard errors when we cluster by industry or industry-year.

The coefficient of interest is $\beta$. Given the $\log$-linear specification, $\beta$ is a semi-elasticity and thus has a simple interpretation: $\beta$ is the percentage change in $y_{i t}$ due to a violation. To facilitate the interpretation of the results, the tables also present the marginal effects of a violation evaluated at the sample average of $y_{i t}: \partial y_{i t} / \partial v_{i t-2}=\beta \bar{y}$.

We consider either the number of independent directors or the number of non-independent directors as the outcome variable, not the ratio between them or the ratio of independents to board size. We choose this approach because it is more informative and general than focusing on ratios; we can always calculate the effect on the ratio from the effects on the levels. In particular, ratios do not indicate what happens to board size after violations, while our approach allows us to infer changes in both the proportion of different types of directors and the total number 
of directors. In the robustness section, we also present results in which $y_{i t}$ is the fraction of independent directors on the board.

We lag all explanatory variables by two years. There are three reasons to expect a lag between the first covenant violation and changes to the board. First, the date of a covenant violation (actual or implied) may indicate the start of negotiations between the firm and its lenders. Such negotiations may result in future agreements, such as new credit or forbearance agreements. Such agreements may then require (formally or informally) the appointment of new directors to the board. The lag between an initial covenant violation and a follow-up agreement which requires board changes can be substantial. In the Internet Appendix, we describe an example of explicit creditor intervention (Peekay Boutiques Inc.) in which lenders demand the appointment of new board members in a contract signed two years after the first violation. There are also cases of lags between an agreement and the date in which new directors are appointed (see the case of Quadrant 4 System Corporation in the Internet Appendix). And even when changes occur shortly after a violation, they may still be recorded with a lag of one year, if the appointment is effective only in the next fiscal year (see the case of RCS Capital Corporation in which an appointment occurs only five days after the agreement, but in a new fiscal year).

Second, directors can normally be replaced only at regular intervals of no less than one year at annual shareholder meetings and often up to three years in the case of firms with staggered-board provisions in their charters. Typically, new directors have to be nominated well in advance of annual meetings. State corporate law and a firms's charter regulate the appointment of directors. These rules may imply a significant lag between the decision to appoint a new director and its actual implementation 10

Finally, we note that, because board turnover is typically low, the effect of violations on appointments is cumulative: The effect in two years is (approximately) the sum of year 1 and year 2 appointments. In the Internet Appendix, we present estimates using alternative lags.

As is typical in regression discontinuity designs, the sample includes only those observations for which the absolute value of the binding distance is less than $h$ (the bandwidth). We

\footnotetext{
${ }^{10}$ Of course, there are also situations in which appointments can be made quickly, such as when directors resign or when a new position is created and temporarily filled until the next formal election (e.g., Arena and Ferris (2007)).
} 
do not use a theoretically motivated bandwidth selection criterion (for example, Imbens and Kalyanaraman (2012)) because some of the necessary assumptions are unlikely to hold in our application. We choose instead an ad hoc narrow bandwidth $(h=0.4)$ as the baseline, which generates a sample that includes 665 observations (24\% of the full sample) ${ }^{11}$ The standard deviation of the binding distance is 1.45 (see Table 1); thus, one unit of binding distance is equivalent to 0.69 of a standard deviation. Therefore, the $h=0.4$ bandwidth is roughly equivalent to 0.28 of a standard deviation.

The standard regression discontinuity design implies that observations around the threshold are (as good as) random. Thus, if the bandwidth is sufficiently narrow, we should expect an almost equally balanced sample size on each side of the threshold. Table IA.4 in the Internet Appendix shows that the samples on each side of the threshold for the baseline bandwidth $(h=0.4)$ are not balanced. The split between $v_{i t}=0$ and $v_{i t}=1$ is approximately $68 \%$ and $32 \%$, respectively. One possible reason that observations cluster on one side of the threshold is the choice of an insufficiently narrow bandwidth. Table IA.4 also shows that the samples become more balanced as we narrow the bandwidth. In particular, with $h=0.2$ (approximately $14 \%$ of a standard deviation) the split is 54\%-46\%, which appears fairly random. This suggests that our choice of bandwidth is the likely cause of the sample imbalance. The trade-off we face is that narrower bandwidths improve sample balance but reduce sample size. Because one might be instinctively skeptical of estimates from subsamples containing only $10 \%$ or less of the full sample, we choose to focus on the relative large sample defined by $h=0.4$ and check the robustness of the results to larger and smaller bandwidth choices.

Another possible reason for sample imbalance is manipulation: Firms may manipulate earnings to avoid breaching the threshold. Although sample balance does not appear to be an issue for sufficiently low $h$ 's, we cannot a priori rule out manipulation or other similar sample selection concerns, such as survivorship bias ${ }^{12}$ We thus use the panel structure of our data to mitigate concerns about the non-random nature of the subsamples to the right and to the left of the threshold. By including firm fixed effects, we ensure that our results are driven by firms

\footnotetext{
${ }^{11}$ We drop observations from firms that appear in this sample in only one year; the reported number of observations thus includes only observations that are not fully explained by firm fixed effects.

${ }^{12}$ Chava and Roberts (2008) provide various arguments and tests suggesting that accounting manipulation to avoid covenant violations is both unlikely and difficult to implement (see also Roberts and Whited (2013)).
} 
that are on both sides of the threshold, which is particularly useful for addressing survivorship bias. This comes at the cost of some loss of external validity; that is, our results are valid only for those firms that can be observed both in state $v_{i t}=0$ and in state $v_{i s}=1$, where $s \neq t$. This may be a non-random sample of firms.

The combination of fixed effects and the use of observations near the threshold mitigates concerns about omitted variables. With fixed effects, our key identification assumption is that the expectation of an imminent increase in board independence does not make firms less likely to manipulate earnings to avoid covenant violations. Although we cannot test this assumption, it is plausible. However, as is the case with any identification assumption, it may be invalid ${ }^{13}$

\subsection{Discontinuity Sample: Descriptive Statistics}

Table 2 presents average values for each variable on each side of the threshold for the discontinuity sample with the baseline bandwidth $(h=0.4)$. We find that narrow violators have significantly higher leverage than narrow non-violators. This is a mechanical result; leverage directly affects the variable that defines a violation. There are no statistically significant differences in the other firm characteristics. In particular, board characteristics - past, current, and future - are similar on both sides of the threshold.

Table IA.5 in the Internet Appendix reports the same comparison for the complement of the discontinuity sample. There are many economically and statistically significant differences, including firm size, leverage, number of segments, market-to-book, volatility, free cash flow, return on assets, and CEO tenure.

Panel A of Table IA.6 in the Internet Appendix presents summary statistics for the discontinuity sample $(h=0.4)$. Compared to the full sample statistics in Table 1 , firms in the the discontinuity sample are smaller (average value of assets $\$ 2.7$ billion) and more levered (31\%). They are also more likely to violate covenants (32\%). These differences are unsurprising; by definition, the discontinuity sample contains only observations that are close to the violation threshold. All other variables in Table IA.6 appear similar to those in the full sample.

\footnotetext{
${ }^{13}$ Note that our approach does not require manipulation to be nonexistent or random. Our analysis remains valid if manipulation is related to time-invariant firm characteristics or to changing characteristics included in our regressions.
} 
For completeness, Panel B presents summary statistics of all observations that are not in the discontinuity sample.

\section{Empirical Results}

\subsection{Graphical Analysis}

Figure 1 illustrates our main finding using the raw data. This figure plots the evolution of the ratio of independent to non-independent directors (annual cross-sectional averages) in the four years before and after an implied covenant violation. The figure shows a clear increase in board independence in the years following a violation. Figure 1 makes it clear that we do not need sophisticated econometrics to uncover our main finding.

Panel A of Figure 2 plots estimates of nonparametric regressions of the number of independent directors on (the negative of) the binding distance. To facilitate the visualization, we reverse the convention in definition (1), such that - in the figures only-negative values on the $x$-axis represent a non-violation and positive values represent a violation. The figure shows only observations in the interval $[-0.4,0.4]$. We run separate regressions for each side of the threshold. To be consistent with the regression model in (3), we measure the dependent variable at year $t+2$. The thick lines are fitted regression lines, and the thin lines are $95 \%$ confidence intervals. The regression uses an Epanechnikov kernel with a bandwidth of 0.05.

Figure 2 shows a clear discontinuity at the threshold. The average number of independent directors increases by approximately 0.8 after a violation. Figure 2 also shows that the number of independent directors declines as the firm approaches a violation threshold, jumps upward at the threshold, and then resumes its decline thereafter. Although we have no reason to predict such a pattern, we note that the relationship between the number of independent directors and the binding distance appears similar on both sides of the threshold.

The nonparametric results show clear evidence of an increase in the number of independent directors following a violation, but these results are subject to some concerns. One specific concern is that a small number of firms that experience multiple violations could explain the 
estimated effects. To address this concern, we define a first violation indicator as

$$
v_{i t}^{\prime}=\left\{1 \text { if } v_{i t}=1 ; 0 \text { if } v_{i s}=0 \text { for all } s<t \text {; missing otherwise }\right\} .
$$

That is, $v_{i t}^{\prime}$ considers only the first violation event experienced by firm $i$. After such an event, we assume that the firm never returns to a non-violation state. Panel B of Figure 2 replicates Panel A using the first violation indicator. We find that, if anything, the discontinuity appears more pronounced in this sample; the implied effect is approximately 1.2 directors.

Finally, Figure IA.1 in the Internet Appendix plots estimates of the effect of violations on the number of non-independent directors. Covenant violations appear to reduce the average number of non-independent directors, but the effect is statistically less precise (in addition to being economically less important) than that for the number of independent directors. This is indeed confirmed by the parametric analysis below.

\subsection{Primary Results}

Table 3 reports our primary results. The dependent variable is the logarithm of the number of independent directors. Column (1) of Panel A reports the estimate of $\beta$ from a (local) regression that includes firm fixed effects, year fixed effects, and a second-order polynomial of the binding distance on each side of the discontinuity. The estimated $\beta$ is positive and statistically significant. An implied covenant violation leads to an increase of $24 \%$ in the number of independent directors. This implies an increase of $0.24 \times 6.4=1.5$ independent directors, evaluated at the (full) sample average of the number of independent directors. ${ }^{14}$ This effect is approximately twice the effect in Figure 2, which suggests that the inclusion of firm and year fixed effects amplifies the effect of violations on board independence. The estimated effect is also economically important and much larger than those documented in most of the empirical literature on boards (see the discussion in Ferreira, Ferreira, and Raposo (2011)) 15

\footnotetext{
${ }^{14}$ As expected, this result is driven primarily by firms with lower board independence. For firms with a belowmedian number of independent directors, the estimated $\beta$ is $0.33(t=2.96)$, while for those with above-median independence, the estimated $\beta$ is 0.07 and statistically insignificant.

${ }^{15}$ In virtually all regressions of board independence on firm characteristics in the literature, the economic significance of the estimated effects is low. For example, Boone, Casares Field, Karpoff, and Raheja (2007) report that a one-standard-deviation increase in firm size is associated with a 1.79-percentage-point increase in
} 
The specification in column (2) includes a long list of control variables: operating performance (return on assets), growth opportunities (market-to-book), firm size (assets), leverage, firm age, number of business segments, R\&D-to-assets ratio, stock return volatility, free cash flow, governance index (Gompers, Ishii, and Metrick (2003)), and CEO ownership and tenure. All of these variables are lagged by two years. To save space, we do not report the coefficients of the control variables ${ }^{16}$ We find that neither market-to-book nor return on assets appears to be negatively related to board appointments. Although return on assets enters negatively, its coefficient is neither economically meaningful $(-0.78)$ nor statistically significant $(t=-1.16)$. A one-standard-deviation decrease in return on assets $(-0.08)$ implies a less than $1 \%$ increase in the number of independent directors. Surprisingly, market-to-book enters positively, but it is statistically insignificant $(t=1.55)$ and economically small: For the average firm, a $60 \%$ increase in market-to-book (equivalent to one standard deviation) leads to an $8 \%$ increase in the number of independent directors. Among the control variables, only $(\log )$ firm age $(0.19, t=1.96)$ and $(\log )$ number of segments $(0.11, t=2.27)$ display statistically significant coefficients.

The most important conclusion from column (2) is that the estimated $\beta$ is virtually identical to that in column (1), which suggests that omitted variables are unlikely to explain our results. While these firm characteristics may be jointly determined with the expectation of future changes in board composition, it is reassuring that the inclusion of these variables does not seem to affect the estimates in an economically meaningful way. We confirm the irrelevance of these firm characteristics by replicating the regression in column (1) using firm characteristics as dependent variables. These are "balancing tests," as in Falato and Liang (2016). Table IA.8 in the Internet Appendix reports a summary of these results. We find that implied covenant violations do not appear to have an economically or statistically significant (contemporaneous) effect on any of the firm characteristics used in our analysis. This indicates that violations cannot explain contemporaneous differences in firm characteristics, after controlling for the binding distance and firm and year fixed effects. Violations may still affect the future value of some of these variables, as the related literature reports and as we also show later.

the fraction of independent directors, which corresponds to an approximately one-tenth increase in the number of independent directors. The economic effect of other important determinants of board independence (e.g., firm age, number of business segments, CEO tenure and ownership) is similar.

${ }^{16}$ Table IA.7 in the Internet Appendix reports the coefficients of the control variables. 
As an alternative means of controlling for time-invariant unobserved firm heterogeneity, in columns (3) and (4), we estimate our model using first differences. We find that the estimated $\beta$ is larger at 0.30 and 0.27 . Finally, for comparison, we also estimate the same regressions without firm fixed effects, including industry (two-digit SIC) fixed effects. In columns (5) and (6), the estimated $\beta$ is 0.32 and 0.23 , respectively. Thus, firm fixed effects do not appear to affect the estimates significantly, especially after the introduction of firm-level controls.

Panel B shows results using two alternative definitions of the covenant violation dummy. The first definition is the first violation indicator, as defined in equation (4). This variable considers only the first (implied) violation episode for each firm (i.e., we assume that the firm never returns to a non-violation state). Using this variable addresses the concern that changes from $v_{i t-1}=0$ to $v_{i t}=1$ may not be symmetric to changes from $v_{i t-1}=1$ to $v_{i t}=0$; while the former leads to a covenant violation, the latter does not (necessarily) reverse an earlier violation.

The second definition follows Nini, Smith, and Sufi (2012). We define a new violation as a violation event that follows a non-violation event. That is, we drop all firm-year observations such that $v_{i t}=1$ and $v_{i t-1} \neq 0$. Nini, Smith, and Sufi (2012) argue that new violations "represent the first opportunity for creditor intervention and thus provide the cleanest identification of the effect of violations on corporate behavior" (p. 1724).

In columns (1)-(3), which use the first violation indicator, the estimated $\beta$ rises to 0.34 , that is, a substantially higher marginal effect of 2.2 new directors (evaluated at the sample mean). This estimate is also remarkably stable across methods. In columns (4)-(6), which use the new violation indicator, the estimated $\beta$ ranges from 0.25 (fixed effects) to 0.38 (OLS). We conclude that our results are not driven by multiple or "stale" violations.

Table 4 replicates the regression analysis above using the logarithm of the number of nonindependent directors as the dependent variable. The estimates show that violations also increase board independence by reducing the number of non-independent directors on boards of directors. However, this effect is statistically and economically weak. In addition, the estimated $\beta$ is not robust across different specifications and definitions. Comparing Table 3 with Table 4 reveals that the number of new appointments is two to three times larger than the number of insider departures. Thus, the new outside directors are typically not replacements 
for resignations by insiders; board size increases after violations.

Overall, we find robust evidence of an economically important effect of implied covenant violations on board independence. The appointment of new directors following violations explains most of this effect. By contrast, there is no evidence of a similar increase in the number of non-independent directors. Thus, board independence unambiguously increases following violations. The joint evidence from Tables 3 and 4 shows that newly appointed directors are not replacements for departing directors.

\subsection{Polynomial Order and Bandwidth Choice}

There is no generally accepted criterion for choosing the polynomial order in regression discontinuity designs. Although the use of high-order polynomials is common in the literature, Gelman and Imbens (2014) advise against using polynomials of order higher than 2. Polynomials of order 2 have additional attractive properties. Calonico, Cattaneo, and Titiunik (2014) show that, under certain conditions, one can adjust for the bias of a local-linear estimator by constructing confidence intervals based on the local-quadratic estimator. Although these are compelling reasons to choose a second-order polynomial as the baseline, we also experiment with different polynomial orders and bandwidth choices, as recommended by Roberts and Whited (2013).

Table 5 reports the estimates of $\beta$ for a combination of six different bandwidths $(h=0.3$ to 0.5 and the full sample) and polynomial orders (1 to 5$)$, using the logarithm of the number of independent directors as the outcome variable. We do not include other firm-level characteristics as controls, but the results are similar when we include them.

Consider first the choice of polynomial order. For the baseline bandwidth $(h=0.4)$ and with a polynomial of order 1 (i.e., a local-linear regression), the estimated $\beta$ is 0.07 and statistically insignificant. With our preferred specification (order 2), the estimate is 0.24 . For polynomials of order 3 or higher, the estimated $\beta$ ranges between 0.20 and 0.30 . Choosing the narrowest bandwidth $(h=0.3)$ reduces the number of observations by almost half. The point estimate of $\beta$ is approximately the same (0.22) as that for the baseline bandwidth. Although the confidence intervals are wider, which is expected because of the smaller sample size, all estimated effects are statistically significant. Larger bandwidths $(h=0.45$ or $h=0.5)$ lead to slightly lower point estimates of $\beta$ for polynomials of orders 1 and 2 , but polynomial order has little impact 
on $\beta$ for orders of 3 or higher. We conclude that the effect of violations on the number of independent directors is robust to polynomial order and bandwidth choice.

An alternative to local regressions is global regressions with high-order polynomials. While this approach is considered inferior to local regressions by some authors (e.g., Imbens and Kalyanaraman (2012) and Gelman and Imbens (2014)), for completeness, we report (in column (6)) the estimates from global regressions. The global regression results are consistent with the hypothesis that board independence increases after covenant violations, but such results underscore the limitations of this approach. Global regressions require high-order polynomials, unless there are a priori reasons to assume that the relationship between the outcome variable and the running variable is smooth. However, high-order polynomials create a number of issues (Gelman and Imbens (2014)). One issue is that estimates are often sensitive to the polynomial order. We find that, for lower-order polynomials (orders 1 to 4 ), the estimated $\beta$ is positive but small and only statistically significant for order 1. For polynomials of order equal to or higher than 5 (untabulated), the estimated $\beta$ is always statistically significant, although generally lower than that estimated with local regressions.

\subsection{Discontinuity-based Exogeneity Tests}

Firm fixed effects address the problem of time-invariant omitted variables, and the large number of firm controls further mitigates concerns about time-varying omitted variables. Nevertheless, we cannot completely exclude the possibility that time-varying omitted variables explain the relationship between covenant violations and board independence. For example, there could be firm-specific trends or cycles that appear to coincide with violation events.

Under mild assumptions, we can formally test for omitted variables by means of a series of placebo tests. Following Caetano (2015), we interpret our tests as discontinuity-based exogeneity tests. Consider the following model:

$$
\begin{gathered}
\ln y_{i t}=\beta_{d} v_{i t-2}^{d}+\gamma_{1} D_{i t-2}+\gamma_{2} D_{i t-2}^{2}+v_{i t-2}^{d}\left(\gamma_{3} D_{i t-2}+\gamma_{4} D_{i t-2}^{2}\right)+\alpha_{t}+f_{i}+u_{i t}, \\
v_{i t-2}^{d}=\left\{\begin{array}{ll}
1 & \text { if } D_{i t-2} \leq d \\
0 & \text { if } D_{i t-2}>d
\end{array} .\right.
\end{gathered}
$$


That is, if $d=0, v_{i t-2}^{0}$ equals the real threshold indicator, $v_{i t-2}$. All other $d \neq 0$ define "fake" or "placebo" thresholds. Formally, we perform a series of tests for the null $\mathbb{H}_{0}: \beta_{d}=0$ against the alternative $\mathbb{H}_{1}: \beta_{d} \neq 0$, for a set of $d \in[-h, h]$. That is, we run the same regressions as before, after replacing the true threshold $v_{i t-2}$ with a fake threshold $v_{i t-2}^{d}, d \neq 0$.

Under the assumption that the true relationship between $y_{i t}$ and $D_{i t-2}$ is continuous (plus a few additional regularity assumptions; see Caetano (2015)), a rejection of the null $\beta_{d}=0$ implies that $D_{i t-2}$ is not (locally) exogenous at $d$; this rejection indicates that there exists at least one omitted variable that creates a discontinuity at point $D_{i t-2}=d \sqrt{17}$

To implement these tests, we first create eight different fake thresholds that are equally distant from one another. These placebo thresholds lie in the interval defined by $d \in[-0.4,0.4]$, which includes the real threshold. Each $d$ is 0.1 units away from an adjacent threshold. To facilitate comparison with our previous results, we implement such tests using the analog of equation (3) instead of equation (5): For each placebo threshold, we redefine the binding distance variable such that it becomes centered at the new threshold. We then redefine the discontinuity sample accordingly and estimate the number of independent directors regression in column (1) of Table 3 for each placebo threshold.

Table 6 shows the results. For all values of $d \neq 0$, we cannot reject the null that $\beta_{d}=0$ at the $5 \%$ significance level (the null is rejected at $10 \%$ only for $d=0.3$, but the estimated effect is negative and economically small at -0.06). Furthermore, most estimates are economically close to zero, with magnitudes in the range $[-0.06,0.11]$, and display changes in sign that follow no particular pattern. By contrast, the estimated effect at the true threshold is statistically and economically strong at $\beta_{0}=0.24$.

We believe that these placebo tests provide the strongest evidence in favor of a causal interpretation of our findings. In the presence of fixed effects, the main source of endogeneity is (time-varying) omitted variables. Our placebo tests fail to detect such omitted variables at values of the forcing variable that differ from the true covenant violation threshold.

\footnotetext{
${ }^{17}$ Our placebo test can be interpreted as a parametric version of Caetano (2015) exogeneity tests without instruments. She shows that such tests only have nontrivial power for alternatives in which an omitted variable creates a discontinuity in the distribution of unobservables. The test is not meant to rule out omitted variables (exogeneity is the null) but rather to detect cases in which omitted variables are likely.
} 


\subsection{Possible Mismeasurement of Covenant Violations}

Are the estimates sensitive to our measure of covenant violations? We address this question by considering a different definition of covenant violations: violations that are registered with the SEC, as in Roberts and Sufi (2009) and Nini, Smith, and Sufi (2012). Henceforth, we refer to this variable as registered violations. The registered violation variable is constructed using information from the SEC's 10-Q and 10-K filings ${ }^{18}$ Nini, Smith, and Sufi (2012) use an algorithm to identify financial covenant violations in credit agreements for publicly traded firms. They construct an indicator variable of whether the firm reports a violation of a financial covenant during each quarter.

A limitation of the registered violation measure is that we do not know which covenant is responsible for a reported violation. Therefore, to measure the binding distance, we need to infer from accounting data which covenant has been violated. This procedure reduces the sample size and may create other forms of measurement errors. We thus consider four different ways of using registered violations.

First, we use registered violations to eliminate "false negatives," which we define as cases in which we observe a registered violation but not an implied violation. We drop all firm-year observations for which (1) there is no implied violation but there is a registered violation in one of the previous four quarters or (2) we do not have data on registered violations. This procedure eliminates 75 observations from the discontinuity sample, or $11 \%$ of that sample. We expect this correction to improve measurement quality because a false negative is hard evidence of mismeasurement. Table 7 reports the results in columns (1) (without firm-level controls) and (2) (with firm-level controls). We find that correcting for false negatives has no effect on the estimates: The number of independent directors increases by $24 \%$ after a covenant violation 19

Second, we use registered violations to eliminate "false positives," which are cases in which we have an implied violation but find no registered violation in the current or following year. Eliminating false positives is a more controversial procedure than eliminating false negatives. False positives will often occur when a violation is waived or renegotiated before the need

\footnotetext{
${ }^{18}$ The data are available at Amir Sufi's website at http://faculty.chicagobooth.edu/amir.sufi/data.html.

${ }^{19}$ Table IA.9 in the Internet Appendix shows that estimates are close to zero when we estimate the placebo tests in Table 6 using this sample of registered violations.
} 
to report it. Thus, false positives could indicate a less serious violation but one that could nonetheless affect board composition. Dropping all false positives eliminates 257 observations from the discontinuity sample, or $39 \%$ of that sample. False positives are quite frequent; just over $80 \%$ of all implied violations are not registered. This suggests that renegotiation and the waiving of covenants are frequent occurrences (Roberts (2015) and Denis and Wang (2014)).

Columns (3) and (4) of Table 7 report the results using only registered violations (i.e., after correcting for false positives). We find that using only registered violations significantly increases the estimated $\beta$ : The number of independent directors increases by $49 \%$ after a violation. Due to a significant reduction in sample size, this effect is less precisely estimated, but it is still statistically significant at the $10 \%$ level. A larger effect when using only registered violations is somewhat expected; registered violations are likely to be the most serious violations and thus more likely to have consequences for borrowers.

Third, we simultaneously correct for both false negatives and false positives . This eliminates 293 observations from the discontinuity sample, or $44 \%$ of that sample. Columns (5) and (6) report the results. The estimated $\beta$ is 0.5 and statistically significant at the $10 \%$ level.

Finally, we can also simply replace the implied violation measure with the registered violation measure, without attempting to infer which covenant is associated with an observed registered violation. Under this approach, we cannot calculate the binding distance, and thus, we also cannot define the discontinuity sample. The best we can do here is to work with the full sample and control for accounting variables that may be used in credit agreements.

We report the full sample analysis in the Internet Appendix. The sample that results from merging the registered violation data with the IRRC data yields 1,296 firms and 8,514 firmyear observations. Table IA.10 in the Internet Appendix presents descriptive statistics of the variables in our study using this sample. Figure IA.2 in the Internet Appendix replicates Figure 1 with this alternative sample. We find that the evolution of the ratio of independent to nonindependent directors around a covenant violation is similar to that in Figure 1. In fact, the two figures are noticeably similar, clearly showing that the ratio of independent to non-independent directors increases following a violation.

Next, following Roberts and Sufi (2009) and Nini, Smith, and Sufi (2012), we estimate a 
"quasi-discontinuity" specification:

$$
\ln y_{i t}=\beta v_{i t-2}+\boldsymbol{\delta} \mathbf{h}\left(\mathbf{x}_{i t-2}\right)+\alpha_{t}+f_{i}+\varepsilon_{i t},
$$

where $\mathbf{h}\left(\mathbf{x}_{i t-2}\right)$ denotes a vector of functions of control variables, including those variables on which covenants are written. We include third-order polynomials and quintile indicator variables for each of the following five variables: leverage, return on assets, interest expenseto-assets ratio, net worth-to-assets ratio, and cash-to-assets ratio. Table IA.11 in the Internet Appendix reports the estimates of equation (7). All specifications produce similar estimates. The semi-elasticity of the number of independent directors to covenant violations is approximately $4 \%$. The size of the effects, especially compared to those in the discontinuity samples when we use registered violations only, suggests that controlling for the distance to a violation substantially increases the estimates. When we use the number of non-independent directors as the dependent variable, we find a negative effect of covenant violations, but as before, the effect is statistically insignificant.

We conclude that the effect of covenant violations on board independence does not depend on our particular measure of covenant violations. We also find that, when using registered violations in the discontinuity sample, the estimated effects are economically stronger (but statistically weaker) than those obtained with implied violations, indicating that more serious violations have stronger consequences for board composition.

\subsection{Robustness}

Table IA.12 in the Internet Appendix reports the results of several robustness tests: (1) Poisson regressions; (2) regressions that exclude CEO turnover events; (3) excluding debt-to-EBITDA covenants; (4) adding interest coverage covenants; (5) splitting the sample into two periods, before and after the Sarbanes-Oxley Act (SOX); (6) extending the sample to include observations after 2008, up to 2014; and (7) using the ratio of independent directors to board size as the outcome variable. Tables IA.13 to IA.20 in the Internet Appendix report additional robustness checks such as using different lag structures, controlling for past stock returns, and using different criteria to determine which observations are retained in the discontinuity sample. 


\section{Mechanisms and Consequences}

\subsection{Who are the directors appointed after covenant violations?}

We use directors' employment information to investigate whether there may be (indirect) links to banks. We consider a director to be connected to a bank if the director holds a position (board or non-board) in a firm that borrows from the same bank. To measure these connections, we consider links via banks (lead arrangers or other participants) in outstanding syndicated loans. In the full sample, we find that $53 \%$ of all directors are connected to current banks. Of these connections, $88 \%$ happen through lead arrangers.

We estimate the regression in equation (3) using as the outcome variable either the logarithm of one plus the number of connected independent directors or the logarithm of one plus the number of unconnected independent directors. Table 8 shows the results. Column (1) shows our preferred specification (the analog of column (1) in Table 3 with firm and year fixed effects and no control variables). An implied covenant violation increases the number of connected independent directors by $18 \%$. Columns (2) and (3) show that our findings are robust to different specifications. By contrast, columns (4)-(6) show that unconnected directors explain a negligible fraction of the effect of violations on board appointments; the effect is economically small $(5 \%)$ and statistically insignificant. ${ }^{20}$

The results in Table 8 show that violations explain the increase in the number of directors with indirect links to current banks. Given that about half of all directors have such indirect links, this finding is perhaps unsurprising. A relevant question is thus whether directors appointed outside violation events also have such connections. In other words, are directors appointed following violations more likely to have indirect links to banks than those appointed outside violation events?

To answer this question, we collect additional data on all newly appointed independent directors within two years after a firm first violates a covenant (i.e., the first time that we observe a change from $v_{i t-1}=0$ to $v_{i t}=1$ ). We identify 226 directors for which current and

\footnotetext{
${ }^{20}$ Table IA.21 in the Internet Appendix shows estimates of the regressions in Table 8, columns (1)-(3), for the number of connected independent directors through lead arrangers and other participants in the loan syndicate. We find that the results are economically stronger (in terms of marginal effects) when we measure connections through lead arrangers than through other participants.
} 
past employment data (in publicly listed firms) are available from the BoardEx database.

To create the control group, we match each new director to a randomly chosen independent director who joined the board in a non-violation year (to maximize the number of matches, we consider the two years before the first violation). With this matching criterion, we match only 129 directors. Of these 129 new directors, 109 work for firms for which we are able to obtain syndicated loan data. Table 9 presents sample averages of the characteristics of new directors and directors in the control group. We find that newly appointed directors are not substantially different from directors in the control group in most characteristics. The main exception is the bank connection variable. We find that $75 \%$ of the directors appointed after implied violations have connections to their firms' current banks, while only $40 \%$ of the control group have connections to current banks. The difference between the two groups - $35 \%$ - is statistically significant, with a $t$-statistic of $5.932^{21}$

We also construct a variation of the bank connection variable, in which we consider only connections through banks in the syndicate of the loan contract for which a violation occurs. We find that $69 \%$ of the new directors are connected to the banks of a syndicated loan with a recent covenant violation (i.e., $92 \%$ of all connections occur via banks of the loan contract that triggered the violation). In the control group, however, only $31 \%$ of the directors have connections to the banks in the syndicate of the loan for which a violation occurs. The difference is $38 \%$, with a $t$-statistic of 6.84 .

In sum, we find that implied covenant violations increase the number of directors with links to the firm's current banks, and that directors appointed after violations are significantly more likely to have connections to banks than directors appointed outside these events. These results indicate that those with power to influence director nominations believe that, following violations, connected directors are particularly beneficial to their interests. However, the evidence cannot tell us who the main beneficiaries are: creditors, managers or shareholders.

\subsection{What happens after new directors are appointed?}

In this section, we examine what happens when new directors are appointed following violations. We identify all first violations in the $h=0.4$ subsample, and create a subsample of firms that

\footnotetext{
${ }^{21}$ Table IA.22 in the Internet Appendix reports the results using two alternative control groups.
} 
experience a first violation. In this subsample, we create a new appointment dummy that takes a value of one if there is an increase in the number of independent directors between year 0 (when a violation occurs) and year 2 (two years after a violation). We consider years $-3,-2$, and -1 as the period before the violation and years 2,3 , and 4 as the period after the violation.

We estimate the following regression:

$$
y_{i t}=\eta a_{i t}+\beta n_{i} a_{i t}+\alpha_{t}+f_{i}+\delta x_{i t}+\varepsilon_{i t},
$$

where $y_{i t}$ is a firm outcome; $a_{i t}$ is the after dummy that takes a value of one for years 2 to 4 after firm $i$ experiences a first violation; $n_{i}$ is the new appointment dummy; $\alpha_{t}$ is a year fixed effect; $f_{i}$ is a firm fixed effect; and $x_{i t}$ is a measure of firm size (the logarithm of assets) ${ }^{22}$ Note that the new appointment dummy for the period before the violation is absorbed by the firm fixed effects, and the after indicator is defined in event-time and thus not absorbed by the year fixed effect. The interpretation of coefficient $\beta$ is similar to that of a difference-in-differences estimator, except that the "treatment" here-an increase in board independence - is certainly endogenous, which means that the estimated $\beta$ should not be interpreted as a causal effect.

Table 10 shows the results. Panel A studies investment, financial and payout policies after covenant violations. Column (1) shows that investment-measured by capital expenditures scaled by lagged property, plant and equipment - decreases in years 2 to 4 after a violation. This result is similar to that in Chava and Roberts (2008), but the horizon is different: While Chava and Roberts (2008) estimate the effects one quarter ahead of a violation, our results suggest that investment rates remain low for a number of years after a violation. The -0.07 coefficient on the after dummy variable implies that, for firms that do not appoint new directors in the post-violation years, the annual investment rate is $7 \%$ (of capital) lower than that in the previolation years. For firms that appoint new directors, there are no economically or statistically significant differences in investment rates before and after the violation; the estimated effect is $-0.07+0.08=0.01$, which is not statistically significant.

Column (2) shows the estimate for net debt issues scaled by lagged assets. The estimate is qualitatively similar to that in Roberts and Sufi (2009), but our results are for a longer

\footnotetext{
${ }^{22}$ We keep the model parsimonious because we have a small sample.
} 
horizon. We find that debt issuance decreases less in firms that appoint new directors, but the difference between the two groups is not statistically significant. Column (3) shows that net equity issues (scaled by lagged assets) increase in years 2 to 4 after a violation. This increase is more pronounced in firms that appoint new independent directors: Annual net equity issuance is $4 \%$ higher in firms that appoint new directors after a violation than in firms with no such appointments; the difference is statistically significant at the $10 \%$ level. Column (4) measures the effect of violations on equity issuance using SEO proceeds (scaled by lagged assets). We find a significant increase in SEO activity in firms that appoint new directors following violations. Column (5) measures the effect on payout using Dividends (scaled by lagged assets). We find a significant decrease in dividends in firms that appoint new directors following violations. Column (6) shows that operational risk - measured by the annualized standard deviation of return on assets (ROA) over the last eight quarters (volatility of ROA) - significantly decreases in firms that appoint new directors following violations.23

In sum, although the evidence here is only suggestive, it indicates more intense equity issuance and investment activity, and dividend cuts in firms that appoint new directors after covenant violations than in firms with no such appointments. In addition, the newly appointed directors appear to take actions that reduce operational risk. While some of these policies are likely to benefit both creditors and shareholders, we note that the dividend cuts and risk reductions are more likely to benefit creditors (see Becker and Stromberg (2012) for similar arguments).

Panel B studies CEO compensation after covenant violations. Columns (1) and (2) show that both total pay and salary do not seem to change significantly after violations. Column (3) shows that cash bonuses (bonus) increase in the years after a violation for firms that do not appoint new independent directors, while cash bonuses actually decrease for firms that appoint new directors. By contrast, column (4) shows that the value of option grants decreases after a violation, but this decrease is much less pronounced in firms that appoint new directors.

Overall, the evidence suggests a narrative in which CEO compensation is tilted toward cash bonuses - and away from options and stock - in firms that do not appoint new directors. By

\footnotetext{
${ }^{23}$ Table IA.23 in the Internet Appendix presents estimates of a variation of equation (8) in which we collapse the data into two periods: before and after covenant violation. We obtain estimates similar to those in Table 10.
} 
contrast, firms with newly appointed directors experience a decrease in cash bonuses and a much smaller decline in options grants. The evidence is consistent with the hypothesis that reformed boards following violations are more likely to favor equity-based compensation over cash-based compensation.

The fact that covenant violations have long-lasting effects may appear puzzling since new appointments occur with a lag. However, most lending relationships between banks and firms involve multiple interactions over a long period of time, and thus banks may care about longlasting effects. Consistent with this reasoning, Table IA.24 in the Internet Appendix shows that the effect of violations on board appointments is stronger in firm-bank pairs with repeated relationships. In addition, the effect of violations on board appointments is more pronounced in firms with stronger lending relationships, firms that are more dependent on bank loans, and firms with less tight covenants at loan origination.

\section{Conclusion}

We show that credit agreements have consequences for the composition of boards of directors. We find that covenant violations lead to the appointment of new independent directors. As a consequence, board size increases. A large number of these newly appointed directors have connections to creditors; these connected directors explain most of the estimated effects.

Our results also show that current and past credit agreements can have long-lasting effects on a firm's governance. In the years after a covenant violation, firms with newly appointed independent directors issue more equity, invest more, pay less dividends, and have less operational risk than those firms that do not reform their boards. This is consistent with firms taking actions to mitigate debt overhang and risk-shifting problems. Firms with new board appointments also have a different $\mathrm{CEO}$ compensation structure in the years following a violation: They are more likely to favor equity-based compensation over cash-based compensation. Since boards are responsible for approving investments, equity issuances, dividends, and CEO compensation, these changes in firm policies are consistent with the hypothesis that more independent boards actively favor policies that are beneficial (not only) to creditors in the post-violation period. 


\section{References}

Aghion, Philippe, and Patrick Bolton, 1992, An incomplete contracts approach to financial contracting, Review of Economic Studies 59, 473-494.

Anderson, Ronald, Sattar Mansi, and David Reeb, 2004, Board characteristics, accounting report integrity, and the cost of debt, Journal of Accounting and Economics 37, 315-342.

Arena, Matteo, and Stephen Ferris, 2007, When managers bypass shareholder approval of board appointments: Evidence from the private security market, Journal of Corporate Finance 13, $485-510$.

Baird, Douglas, and Robert Rasmussen, 2006, Private debt and the missing lever of corporate governance, University of Pennsylvania Law Review 154, 1209-1251.

Becker, Bo, and Victoria Ivashina, 2016, Covenant-light contracts and creditor coordination, Working paper, Stockholm School of Economics.

Becker, Bo, and Per Stromberg, 2012, Fiduciary duties and equity-debtholder conflicts, Review of Financial Studies 25, 1931-1969.

Boone, Audra, Laura Casares Field, Jonathan Karpoff, and Charu Raheja, 2007, The determinants of corporate board size and composition: An empirical analysis, Journal of Financial Economics 85, 66-101.

Caetano, Carolina, 2015, A test of endogeneity without instrumental variables in models with bunching, Econometrica 83, 1581-1600.

Calonico, Sebastian, Matias Cattaneo, and Rocio Titiunik, 2014, Robust nonparametric confidence intervals for regression-discontinuity designs, Econometrica 82, 2295-2326.

Chava, Sudheer, and Michael Roberts, 2008, How does financing impact investment? The role of debt covenants, Journal of Finance 63, 2085-2121.

Coles, Jeffrey, Naveen Daniel, and Lalitha Naveen, 2008, Boards: Does one size fit all, Journal of Financial Economics 87, 329-356. 
Demiroglu, Cem, and Christopher James, 2010, The information content of bank loan covenants, Review of Financial Studies 23, 3700-3737.

Denis, David, and Jing Wang, 2014, Debt covenant renegotiations and creditor control rights, Journal of Financial Economics 113, 348-367.

Dewatripont, Mathias, and Jean Tirole, 1994, A theory of debt and equity: Diversity of securities and manager-shareholder congruence, Quarterly Journal of Economics 109, 1027-1054.

Falato, Antonio, and Nellie Liang, 2016, Do Creditor Rights Increase Employment Risk? Evidence from Loan Covenants, Journal of Finance, 71, 2545-2590.

Ferreira, Daniel, Miguel Ferreira, and Clara Raposo, 2011, Board structure and price informativeness, Journal of Financial Economics 99, 523-545.

Freudenberg, Felix, Bjorn Imbierowicz, Anthony Saunders, and Sascha Steffen, 2017, Covenant violations and dynamic loan contracting, Journal of Corporate Finance, forthcoming.

Gârleanu, Nicolae, and Jeffrey Zwiebel, 2009, Design and renegotiation of debt covenants, Review of Financial Studies 22, 749-781.

Gelman, Andrew, and Guido Imbens, 2014, Why high-order polynomials should not be used in regression discontinuity designs, Working paper no. 20405, NBER.

Gilson, Stuart, 1990, Bankruptcy, boards, banks, and blockholders: Evidence on changes in corporate ownership and control when firms default, Journal of Financial Economics 27, $355-387$.

Gompers, Paul, Joy Ishii, and Andrew Metrick, 2003, Corporate governance and equity prices, Quarterly Journal of Economics 118, 107-155.

Guner, A. Burak, Ulrike Malmendier, and Geoffrey Tate, 2008, Financial expertise of directors, Journal of Financial Economics 88, 323-354.

Hermalin, Benjamin, and Michael Weisbach, 1998, Endogenously chosen boards of directors and their monitoring of the CEO, American Economic Review 88, 96-118. 
Imbens, Guido, and Karthik Kalyanaraman, 2012, Optimal bandwidth choice for the regression discontinuity estimator, Review of Economic Studies 79, 933-959.

Kaplan, Steven, and Bernadette Minton, 1994, Appointments of outsiders to Japanese boards: Determinants and implications for managers, Journal of Financial Economics 36, 225-258.

Kroszner, Randall, and Philip Strahan, 2001, Bankers on boards: Monitoring, conflicts of interest, and lender liability, Journal of Financial Economics 62, 415-452.

Linck, James, Jeffry Netter, and Tina Yang, 2008, The determinants of board structure, Journal of Financial Economics 87, 308-328.

Nini, Greg, David Smith, and Amir Sufi, 2009, Creditor control rights and firm investment policy, Journal of Financial Economics 92, 400-420.

— 2012, Creditor control rights, corporate governance, and firm value, Review of Financial Studies 25, 1713-1761.

Roberts, Michael, 2015, The role of dynamic renegotiation and asymmetric information in financial contracting, Journal of Financial Economics 116, 61-81.

— , and Amir Sufi, 2009, Control rights and capital structure: An empirical investigation, Journal of Finance 64, 1657-1695.

Roberts, Michael, and Toni Whited, 2013, Endogeneity in empirical corporate finance, in Milton Harris George Constantinides, and Rene Stulz, ed.: Handbook of the Economics of Finance. 


\section{Table 1: Summary Statistics}

This table presents mean, standard deviation, minimum, 10th percentile, median, 90th percentile, maximum, number of observations, and number of firms for each variable. The sample consists of annual observations on Investor Responsibility Research Center (IRRC) firms from 1994 to 2008 for which syndicated loans data are available from DealScan. Financial industries are omitted (SIC codes 6000-6999). Board and governance data are from the IRRC database. Executive compensation data are from ExecuComp. Accounting and segment data are from Compustat. Stock return data are from the Center for Research in Security Prices (CRSP). Covenant violation is a dummy variable that takes a value of one if the firm violates at least one out of four covenants (current ratio, net worth, tangible net worth, and debt-to-EBITDA) during the year in at least one quarter. Binding distance is the relative distance between the actual accounting variable and the corresponding covenant threshold. Refer to Table A1 in the Appendix for variable definitions. Financial ratios are winsorized at the bottom and top $1 \%$ level.

\begin{tabular}{|c|c|c|c|c|c|c|c|c|c|}
\hline & Mean & $\begin{array}{l}\text { Standard } \\
\text { deviation }\end{array}$ & Minimum & $\begin{array}{l}\text { 10th } \\
\text { pctile }\end{array}$ & Median & $\begin{array}{c}\text { 90th } \\
\text { pctile }\end{array}$ & Maximum & $\begin{array}{l}\text { Number } \\
\text { of obs. }\end{array}$ & $\begin{array}{l}\text { Number } \\
\text { of firms }\end{array}$ \\
\hline Number of non-independent directors & 2.76 & 1.65 & 1.00 & 1.00 & 2.00 & 5.00 & 13.00 & 2,801 & 597 \\
\hline Number of directors & 9.15 & 2.13 & 4.00 & 7.00 & 9.00 & 12.00 & 19.00 & 2,801 & 597 \\
\hline Number of connected directors & 3.14 & 2.20 & 0.00 & 0.00 & 3.00 & 6.00 & 11.00 & 2,663 & 571 \\
\hline Number of non-connected directors & 2.80 & 1.75 & 0.00 & 1.00 & 3.00 & 5.00 & 10.00 & 2,663 & 571 \\
\hline Firm age & 22.56 & 17.42 & 1.00 & 6.00 & 17.00 & 42.00 & 81.00 & 2,801 & 597 \\
\hline Number of segments & 2.88 & 1.91 & 1.00 & 1.00 & 3.00 & 6.00 & 10.00 & 2,801 & 597 \\
\hline Market-to-book & 1.88 & 1.15 & 0.62 & 1.04 & 1.54 & 3.00 & 8.89 & 2,801 & 597 \\
\hline$R \& D$ & 0.02 & 0.04 & 0.00 & 0.00 & 0.00 & 0.06 & 0.37 & 2,801 & 597 \\
\hline Stock return volatility & 0.38 & 0.20 & 0.12 & 0.19 & 0.34 & 0.63 & 1.74 & 2,801 & 597 \\
\hline Free cash flow & 0.09 & 0.08 & -0.79 & 0.01 & 0.09 & 0.18 & 0.36 & 2,801 & 597 \\
\hline Covenant violation & 0.24 & 0.43 & 0.00 & 0.00 & 0.00 & 1.00 & 1.00 & 2,801 & 597 \\
\hline Binding distance & 0.07 & 1.45 & -7.36 & -0.63 & 0.30 & 0.92 & 4.14 & 2,801 & 597 \\
\hline
\end{tabular}




\section{Table 2: Averages for Violation and Non-Violation Groups - Sample within Bandwidth}

This table presents sample averages of board composition and firm characteristics for observations with no covenant violation and observations with at least one covenant violation. A covenant violation occurs if the firm violates at least one out of four covenants (current ratio, net worth, tangible net worth, and debt-to-EBITDA) during the year in at least one quarter. The sample consists of annual observations on Investor Responsibility Research Center (IRRC) non-financial firms from 1994 to 2008 for which syndicated loans data are available from DealScan. The sample includes observations in which the absolute value of the relative binding distance to the covenant threshold is less than the bandwidth $(h=0.4)$.

\begin{tabular}{lcccc}
\hline & No violation & Violation \\
& $(1)$ & $(2)$ & $\begin{array}{c}\text { Difference } \\
(1)-(2)\end{array}$ & $t$-statistic \\
\hline Number of independent directors (2 leads) & 6.34 & 6.41 & -0.08 & -0.40 \\
Number of independent directors (2 lags) & 5.98 & 5.94 & 0.04 & 0.18 \\
Number of independent directors (1 lag) & 5.99 & 5.89 & 0.10 & 0.47 \\
Number of independent directors & 5.97 & 6.03 & -0.06 & -0.31 \\
Number of non-independent directors (2 leads) & 2.94 & 2.95 & -0.01 & -0.07 \\
Number of non-independent directors (2 lags) & 3.36 & 3.59 & -0.23 & -1.30 \\
Number of non-independent directors (1 lag) & 3.32 & 3.53 & -0.22 & -1.31 \\
Number of non-independent directors & 3.22 & 3.39 & -0.17 & -1.05 \\
& & & & \\
Firm size (\$ millions) & 2,553 & 3,051 & -498 & -1.28 \\
Leverage & 0.29 & 0.35 & -0.06 & -5.03 \\
Firm age & 23.98 & 21.95 & 2.03 & 1.38 \\
Number of segments & 2.96 & 3.03 & -0.06 & -0.38 \\
Market-to-book & 1.47 & 1.48 & -0.01 & -0.24 \\
R\&D & 0.02 & 0.02 & 0.00 & 0.11 \\
Stock return volatility & 0.37 & 0.38 & -0.01 & -0.95 \\
Free cash flow & 0.07 & 0.07 & 0.00 & 1.02 \\
Return on assets & 0.13 & 0.13 & 0.00 & 0.54 \\
Governance index & 9.45 & 9.33 & 0.12 & 0.57 \\
CEO ownership & 0.03 & 0.03 & 0.00 & -0.55 \\
CEO tenure & 8.24 & 7.30 & 0.94 & 1.54 \\
Number of observations & & & & \\
Number of firms & 454 & 211 & & \\
Fraction of observations in violation & 192 & 121 & & \\
Fraction of firms in violation & & 0.32 & & \\
\hline
\end{tabular}




\section{Table 3: Regression of Number of Independent Directors}

This table presents estimates of firm fixed effects, first differences and ordinary least squares (OLS) panel regressions of the logarithm of the number of independent directors. Covenant violation is a dummy variable that takes a value of one if the firm violates at least one out of four covenants (current ratio, net worth, tangible net worth, and debt-to-EBITDA) during the year in at least one quarter. The firm-level control variables are firm size $(\log )$, leverage, firm age (log), number of segments $(\log )$, market-to-book $(\log ), \mathrm{R} \& \mathrm{D}$, stock return volatility, free cash flow, return on assets, governance index, CEO ownership, and CEO tenure. All explanatory variables are lagged two years. Panel A presents estimates using all covenant violations, and Panel B presents estimates using the first covenant violation or new violations for each firm. The sample consists of annual observations on Investor Responsibility Research Center (IRRC) non-financial firms from 1994 to 2008 for which syndicated loans data are available from DealScan. The sample includes only those observations in which the absolute value of the relative binding distance to the covenant threshold is less than the bandwidth $(h=0.4)$. Refer to Table A1 in the Appendix for variable definitions. Robust $t$-statistics adjusted for firm-level clustering are in parentheses. *, **, *** indicates significance at the $10 \%, 5 \%$, and $1 \%$ levels.

Panel A: All Violations

\begin{tabular}{|c|c|c|c|c|c|c|}
\hline & \multicolumn{2}{|c|}{ Firm fixed effects } & \multicolumn{2}{|c|}{ First differences } & \multicolumn{2}{|c|}{ OLS } \\
\hline & $(1)$ & $(2)$ & $(3)$ & (4) & $(5)$ & (6) \\
\hline Covenant violation & $\begin{array}{c}0.24^{* * *} \\
(3.47)\end{array}$ & $\begin{array}{c}0.25^{* * *} \\
(3.66)\end{array}$ & $\begin{array}{c}0.30^{* * *} \\
(3.37)\end{array}$ & $\begin{array}{c}0.27^{* * *} \\
(3.21)\end{array}$ & $\begin{array}{c}0.32^{* * *} \\
(3.30)\end{array}$ & $\begin{array}{c}0.23^{* * *} \\
(2.68)\end{array}$ \\
\hline Marginal effects (at mean) & 1.53 & 1.60 & 1.92 & 1.73 & 2.04 & 1.47 \\
\hline 2nd order polynomial & Yes & Yes & Yes & Yes & Yes & Yes \\
\hline Firm level controls & No & Yes & No & Yes & No & Yes \\
\hline Firm fixed effects & Yes & Yes & No & No & No & No \\
\hline Industry fixed effects & No & No & Yes & Yes & Yes & Yes \\
\hline Year fixed effects & Yes & Yes & Yes & Yes & Yes & Yes \\
\hline$R^{2}$ & 0.176 & 0.249 & 0.137 & 0.167 & 0.301 & 0.497 \\
\hline Number of observations & 665 & 665 & 472 & 472 & 665 & 665 \\
\hline Number of firms & 222 & 222 & 214 & 214 & 222 & 222 \\
\hline
\end{tabular}

Panel B: First and New Violations

\begin{tabular}{|c|c|c|c|c|c|c|}
\hline & \multicolumn{3}{|c|}{ First violations } & \multicolumn{3}{|c|}{ New violations } \\
\hline & $\begin{array}{c}\text { Firm FE } \\
(1)\end{array}$ & $\begin{array}{c}\text { First diff. } \\
(2)\end{array}$ & $\begin{array}{l}\text { OLS } \\
(3)\end{array}$ & $\begin{array}{c}\text { Firm FE } \\
(4)\end{array}$ & $\begin{array}{l}\text { First diff. } \\
(5)\end{array}$ & $\begin{array}{l}\text { OLS } \\
(6)\end{array}$ \\
\hline Covenant violation & $\begin{array}{c}0.34^{* * *} \\
(3.20)\end{array}$ & $\begin{array}{c}0.34^{* * *} \\
(2.75)\end{array}$ & $\begin{array}{c}0.34^{* * *} \\
(2.88)\end{array}$ & $\begin{array}{c}0.25^{* * *} \\
(2.68)\end{array}$ & $\begin{array}{c}0.35^{* * *} \\
(3.22)\end{array}$ & $\begin{array}{c}0.38^{* * *} \\
(3.01)\end{array}$ \\
\hline Marginal effects (at mean) & 2.17 & 2.17 & 2.17 & 1.60 & 2.24 & 2.43 \\
\hline 2nd order polynomial & Yes & Yes & Yes & Yes & Yes & Yes \\
\hline Firm fixed effects & No & No & No & No & No & No \\
\hline Firm fixed effects & Yes & No & No & Yes & No & No \\
\hline Industry fixed effects & No & Yes & Yes & No & Yes & Yes \\
\hline Year fixed effects & Yes & Yes & Yes & Yes & Yes & Yes \\
\hline$R^{2}$ & 0.163 & 0.161 & 0.378 & 0.190 & 0.184 & 0.317 \\
\hline Number of observations & 522 & 350 & 522 & 502 & 357 & 502 \\
\hline Number of firms & 188 & 179 & 188 & 175 & 165 & 175 \\
\hline
\end{tabular}




\section{Table 4: Regression of Number of Non-Independent Directors}

This table presents estimates of firm fixed effects, first differences and ordinary least squares (OLS) panel regressions of the logarithm of the number of non-independent directors. Covenant violation is a dummy variable that takes a value of one if the firm violates at least one out of four covenants (current ratio, net worth, tangible net worth, and debt-to-EBITDA) during the year in at least one quarter. The firm-level control variables are firm size $(\log )$, leverage, firm age $(\log )$, number of segments $(\log )$, market-to-book $(\log ), R \& D$, stock return volatility, free cash flow, return on assets, governance index, CEO ownership, and CEO tenure. All explanatory variables are lagged two years. Panel A presents estimates using all covenant violations, and Panel B presents estimates using the first covenant violation or new violations for each firm. The sample consists of annual observations on Investor Responsibility Research Center (IRRC) non-financial firms from 1994 to 2008 for which syndicated loans data are available from DealScan. The sample includes only those observations in which the absolute value of the relative binding distance to the covenant threshold is less than the bandwidth $(h=0.4)$. Refer to Table A1 in the Appendix for variable definitions. Robust $t$-statistics adjusted for firm-level clustering are in parentheses. $*, * *, * *$ indicates significance at the $10 \%, 5 \%$, and $1 \%$ levels.

Panel A: All Violations

\begin{tabular}{|c|c|c|c|c|c|c|}
\hline & \multicolumn{2}{|c|}{ Firm fixed effects } & \multicolumn{2}{|c|}{ First differences } & \multicolumn{2}{|c|}{ OLS } \\
\hline & (1) & $(2)$ & $(3)$ & (4) & $(5)$ & (6) \\
\hline Covenant violation & $-0.21^{* *}$ & $-0.21^{* *}$ & -0.19 & -0.19 & -0.13 & -0.09 \\
\hline & $(-2.41)$ & $(-2.45)$ & $(-1.44)$ & $(-1.49)$ & $(-0.97)$ & $(-0.75)$ \\
\hline Marginal effects (at mean) & -0.58 & -0.58 & -0.52 & -0.52 & -0.36 & -0.25 \\
\hline 2nd order polynomial & Yes & Yes & Yes & Yes & Yes & Yes \\
\hline Firm level controls & No & Yes & No & Yes & No & Yes \\
\hline Firm fixed effects & Yes & Yes & No & No & No & No \\
\hline Industry fixed effects & No & No & Yes & Yes & Yes & Yes \\
\hline Year fixed effects & Yes & Yes & Yes & Yes & Yes & Yes \\
\hline$R^{2}$ & 0.245 & 0.285 & 0.163 & 0.176 & 0.389 & 0.452 \\
\hline Number of observations & 665 & 665 & 472 & 472 & 665 & 665 \\
\hline Number of firms & 222 & 222 & 214 & 214 & 222 & 222 \\
\hline
\end{tabular}

Panel B: First and New Violations

\begin{tabular}{|c|c|c|c|c|c|c|}
\hline & \multicolumn{3}{|c|}{ First violations } & \multicolumn{3}{|c|}{ New violations } \\
\hline & $\begin{array}{c}\text { Firm FE } \\
(1)\end{array}$ & $\begin{array}{c}\text { First diff. } \\
(2)\end{array}$ & $\begin{array}{l}\text { OLS } \\
(3)\end{array}$ & $\begin{array}{c}\text { Firm FE } \\
(4)\end{array}$ & $\begin{array}{c}\text { First diff. } \\
(5)\end{array}$ & $\begin{array}{l}\text { OLS } \\
(6)\end{array}$ \\
\hline Covenant violation & $\begin{array}{c}-0.35^{* * *} \\
(-2.80)\end{array}$ & $\begin{array}{c}-0.33^{* *} \\
(-2.04)\end{array}$ & $\begin{array}{l}-0.12 \\
(-0.71)\end{array}$ & $\begin{array}{c}-0.40^{* * *} \\
(-3.42)\end{array}$ & $\begin{array}{l}-0.19 \\
(-1.37)\end{array}$ & $\begin{array}{c}-0.19 \\
(-1.17)\end{array}$ \\
\hline Marginal effects (at mean) & -0.97 & -0.91 & -0.33 & -1.10 & -0.52 & -0.52 \\
\hline 2nd order polynomial & Yes & Yes & Yes & Yes & Yes & Yes \\
\hline Firm level controls & No & No & No & No & No & No \\
\hline Firm fixed effects & Yes & No & No & Yes & No & No \\
\hline Industry fixed effects & No & Yes & Yes & No & Yes & Yes \\
\hline Year fixed effects & Yes & Yes & Yes & Yes & Yes & Yes \\
\hline$R^{2}$ & 0.247 & 0.269 & 0.394 & 0.310 & 0.185 & 0.436 \\
\hline Number of observations & 522 & 350 & 522 & 502 & 357 & 502 \\
\hline Number of firms & 188 & 179 & 188 & 175 & 165 & 175 \\
\hline
\end{tabular}




\section{Table 5: Regression of Number of Independent Directors - Alterna- tive Polynomial Orders and Bandwidths}

This table presents estimates of firm fixed effects panel regressions of the logarithm of the number of independent directors. Covenant violation is a dummy variable that takes a value of one if the firm violates at least one out of four covenants (current ratio, net worth, tangible net worth, and debt-to-EBITDA) during the year in at least one quarter. All explanatory variables are lagged two years. The sample consists of annual observations on Investor Responsibility Research Center (IRRC) non-financial firms from 1994 to 2008 for which syndicated loans data are available from DealScan. The sample includes only those observations in which the absolute value of the relative binding distance to the covenant threshold is less than the bandwidth $(h)$. Refer to Table A1 in the Appendix for variable definitions. Robust $t$-statistics adjusted for firm-level clustering are in parentheses. $*, * *, * * *$ indicates significance at the $10 \%, 5 \%$, and $1 \%$ levels.

\begin{tabular}{lccccccc}
\hline & Polyn. & \multicolumn{3}{c}{ Bandwidth } & \multicolumn{2}{c}{ Full } \\
& order & $h=0.3$ & $h=0.35$ & $h=0.4$ & $h=0.45$ & $h=0.5$ & sample \\
& & $(1)$ & $(2)$ & $(3)$ & $(4)$ & $(5)$ & $(6)$ \\
\hline Covenant violation & 1 st & $0.12^{*}$ & $0.11^{* *}$ & 0.07 & 0.05 & 0.04 & $0.03^{* *}$ \\
& & $(1.67)$ & $(2.08)$ & $(1.57)$ & $(1.21)$ & $(1.13)$ & $(2.15)$ \\
Covenant violation & \multirow{2}{*}{ 2nd } & $0.22^{* *}$ & $0.19^{* *}$ & $0.24^{* * *}$ & $0.15^{* * *}$ & $0.14^{* * *}$ & 0.02 \\
& & $(2.35)$ & $(2.54)$ & $(3.47)$ & $(2.76)$ & $(2.97)$ & $(0.96)$ \\
Covenant violation & \multirow{2}{*}{$3 \mathrm{rd}$} & $0.36^{* * *}$ & $0.28^{* * *}$ & $0.20^{* *}$ & $0.23^{* * *}$ & $0.21^{* * *}$ & 0.02 \\
& & $(2.75)$ & $(2.87)$ & $(2.37)$ & $(3.12)$ & $(2.94)$ & $(1.06)$ \\
Covenant violation & \multirow{2}{*}{$4 \mathrm{th}$} & $0.46^{* * *}$ & $0.31^{* *}$ & $0.30^{* * *}$ & $0.23^{* *}$ & $0.23^{* * *}$ & 0.04 \\
& & $(2.82)$ & $(2.49)$ & $(2.82)$ & $(2.54)$ & $(2.80)$ & $(1.36)$ \\
Covenant violation & \multirow{2}{*}{5 th } & $0.41^{* *}$ & $0.42^{* * *}$ & $0.28^{* *}$ & $0.28^{* *}$ & $0.21^{* *}$ & $0.06^{*}$ \\
& & $(2.48)$ & $(2.70)$ & $(2.16)$ & $(2.59)$ & $(2.12)$ & $(1.76)$ \\
& & & & & & & \\
Firm fixed effects & & Yes & Yes & Yes & Yes & Yes & Yes \\
Year fixed effects & & Yes & Yes & Yes & Yes & Yes & Yes \\
$R^{2}$ & & 0.226 & 0.166 & 0.152 & 0.164 & 0.182 & 0.191 \\
Number of observations & & 346 & 503 & 665 & 813 & 976 & 2,801 \\
Number of firms & & 129 & 176 & 222 & 255 & 292 & 597 \\
\hline
\end{tabular}




\section{Table 6: Regression of Number of Independent Directors - Placebo Test}

This table presents estimates of firm fixed effects panel regressions of the logarithm of the number of independent directors. Covenant violation is a dummy variable that takes a value of one if the firm violates at least one out of four covenants (current ratio, net worth, tangible net worth, and debt-to-EBITDA) during the year in at least one quarter. All explanatory variables are lagged two years. The estimates are shown using different distances to the real threshold, which is set at zero. The sample consists of annual observations on Investor Responsibility Research Center (IRRC) non-financial firms from 1994 to 2008 for which syndicated loans data are available from DealScan. The sample includes only those observations in which the absolute value of the relative binding distance to the covenant threshold is less than the bandwidth $(h)$. Refer to Table A1 in the Appendix for variable definitions. Robust $t$-statistics adjusted for firm-level clustering are in parentheses. *, **, *** indicates significance at the $10 \%, 5 \%$, and $1 \%$ levels.

\begin{tabular}{lccccccccc}
\hline & \multicolumn{10}{c}{ Distance to real threshold } \\
\cline { 2 - 11 } & -0.4 & -0.3 & -0.2 & -0.1 & 0.0 & 0.1 & 0.2 & 0.3 & 0.4 \\
& $(1)$ & $(2)$ & $(3)$ & $(4)$ & $(5)$ & $(6)$ & $(7)$ & $(8)$ & $(9)$ \\
\hline Covenant violation & 0.11 & 0.10 & 0.05 & 0.03 & $0.24^{* * *}$ & -0.06 & 0.01 & $-0.06^{*}$ & -0.01 \\
& $(0.55)$ & $(1.00)$ & $(0.41)$ & $(0.33)$ & $(3.47)$ & $(-1.22)$ & $(0.19)$ & $(-1.66)$ & $(-0.23)$ \\
Marginal effects (at mean) & 0.70 & 0.64 & 0.32 & 0.19 & 1.53 & -0.38 & 0.06 & -0.38 & -0.06 \\
& & & & & & & & & \\
2nd order polynomial & Yes & Yes & Yes & Yes & Yes & Yes & Yes & Yes & Yes \\
Firm fixed effects & Yes & Yes & Yes & Yes & Yes & Yes & Yes & Yes & Yes \\
Year fixed effects & Yes & Yes & Yes & Yes & Yes & Yes & Yes & Yes & Yes \\
$R^{2}$ & 0.213 & 0.270 & 0.232 & 0.147 & 0.176 & 0.187 & 0.194 & 0.181 & 0.182 \\
Number of observations & 104 & 151 & 245 & 430 & 665 & 883 & 1,068 & 1,109 & 1,128 \\
Number of firms & 45 & 64 & 97 & 155 & 222 & 272 & 316 & 321 & 325 \\
\hline
\end{tabular}




\section{Table 7: Regression of Number of Independent Directors - SEC- DealScan Matched Sample}

This table presents estimates of firm fixed effects panel regressions of the logarithm of the number of independent directors. Covenant violation is a dummy variable that takes a value of one if the firm violates at least one out of four covenants (current ratio, net worth, tangible net worth, and debt-to EBITDA) during the year in at least one quarter. The firm-level control variables are firm size (log), leverage, firm age (log), number of segments (log), market-to-book (log), R\&D, stock return volatility, free cash flow, return on assets, governance index, CEO ownership, and CEO tenure. All explanatory variables are lagged two years. Columns (1) and (2) drop observations in case the covenant violation dummy is zero but there is a covenant violation according to the SEC's 10-Q or 10-K filings. Columns (3) and (4) drop observations in case the covenant violation dummy is one but there is no covenant violation according to the SEC's 10-Q or 10-K filings. Columns (5) and (6) drop observations in both cases. The sample consists of annual observations on Investor Responsibility Research Center (IRRC) non-financial firms from 1994 to 2008 for which syndicated loans data are available from DealScan. The sample includes only those observations in which the absolute value of the relative binding distance to the covenant threshold is less than the bandwidth $(h=0.4)$. Refer to Table A1 in the Appendix for variable definitions. Robust $t$-statistics adjusted for firm-level clustering are in parentheses. $*, * *, * * *$ indicates significance at the $10 \%, 5 \%$, and $1 \%$ levels.

\begin{tabular}{lcccccc}
\hline & $(1)$ & $(2)$ & $(3)$ & $(4)$ & $(5)$ & $(6)$ \\
\hline Covenant violation & $0.24^{* * *}$ & $0.24^{* * *}$ & $0.49^{*}$ & $0.49^{*}$ & $0.51^{*}$ & $0.50^{*}$ \\
& $(3.35)$ & $(3.64)$ & $(1.86)$ & $(1.93)$ & $(1.72)$ & $(1.76)$ \\
Marginal effects (at mean) & 1.53 & 1.53 & 3.13 & 3.13 & 3.26 & 3.19 \\
& & & & & & \\
2nd order polynomial & Yes & Yes & Yes & Yes & Yes & Yes \\
Firm level controls & No & Yes & No & Yes & No & Yes \\
Firm fixed effects & Yes & Yes & Yes & Yes & Yes & Yes \\
Year fixed effects & Yes & Yes & Yes & Yes & Yes & Yes \\
$R^{2}$ & 0.174 & 0.258 & 0.253 & 0.317 & 0.241 & 0.323 \\
Number of observations & 590 & 590 & 408 & 408 & 372 & 372 \\
Number of firms & 203 & 203 & 146 & 146 & 135 & 135 \\
\hline
\end{tabular}




\section{Table 8: Regression of Number of Connected and Non-Connected Di- rectors}

This table presents estimates of firm fixed effects, first differences and ordinary least squares (OLS) panel regressions of the logarithm of one plus the number of connected directors or unconnected directors. Connected directors are those that have a board or non-board position in another firm with outstanding loans that have at least one bank (lead arranger or other participant) in common with the firm's current banks. Non-connected directors include all other cases. Covenant violation is a dummy variable that takes a value of one if the firm violates at least one out of four covenants (current ratio, net worth, tangible net worth, and debt-to EBITDA) during the year in at least one quarter. The sample consists of annual observations on Investor Responsibility Research Center (IRRC) non-financial firms from 1994 to 2008 for which syndicated loans data are available from DealScan. The sample includes only those observations in which the absolute value of the relative binding distance to the covenant threshold is less than the bandwidth $(h=0.4)$. Refer to Table A1 in the Appendix for variable definitions. Robust $t$-statistics adjusted for firm-level clustering are in parentheses. $*, * *, * * *$ indicates significance at the $10 \%, 5 \%$, and $1 \%$ levels.

\begin{tabular}{lccccccc}
\hline & \multicolumn{3}{c}{ Number of connected directors } & & \multicolumn{3}{c}{ Number of non-connected directors } \\
\cline { 2 - 3 } \cline { 7 - 8 } & Firm FE & First diff. & OLS & & Firm FE & First diff. & OLS \\
& $(1)$ & $(2)$ & $(3)$ & & $(4)$ & $(5)$ & $(6)$ \\
\hline Covenant violation & $0.18^{* *}$ & $0.33^{* * *}$ & $0.33^{* *}$ & & 0.05 & 0.05 & 0.10 \\
& $(2.26)$ & $(2.74)$ & $(2.40)$ & & $(0.60)$ & $(0.39)$ & $(0.83)$ \\
Marginal effects (at mean) & 0.75 & 1.37 & 1.37 & & 0.19 & 0.19 & 0.38 \\
& & & & & & & \\
2nd order polynomial & Yes & Yes & Yes & & Yes & Yes & Yes \\
Firm fixed effects & Yes & No & No & & Yes & No & No \\
Industry fixed effects & No & Yes & Yes & & No & Yes & Yes \\
Year fixed effects & Yes & Yes & Yes & & Yes & Yes & Yes \\
$R^{2}$ & 0.060 & 0.168 & 0.281 & & 0.133 & 0.119 & 0.257 \\
Number of observations & 623 & 439 & 623 & & 623 & 439 & 623 \\
Number of firms & 207 & 199 & 207 & & 207 & 199 & 207 \\
\hline
\end{tabular}




\section{Table 9: Characteristics of Independent Directors Appointed after Covenant Violations}

This table reports sample averages of the characteristics of new independent directors appointed in the two years after a firm first violates a covenant and a matched control group of independent directors. To construct the control group, a new director is matched to a randomly-chosen independent director in the same firm. The control group includes independent directors who joined the board in the two years before the first violation. Director characteristics are from the BoardEx database. Refer to Table A1 in the Appendix for variable definitions.

\begin{tabular}{lccccc}
\hline & $\begin{array}{c}\text { New } \\
\text { directors }\end{array}$ & $\begin{array}{c}\text { Control } \\
\text { group }\end{array}$ & Difference & t-statistic & $\begin{array}{c}\text { Number } \\
\text { of obs. }\end{array}$ \\
\hline Male & 0.91 & 0.86 & 0.05 & 1.30 & 129 \\
Age & 55.83 & 54.55 & 1.28 & 1.42 & 129 \\
MBA & 0.18 & 0.16 & 0.02 & 0.33 & 129 \\
Financial education & 0.25 & 0.26 & -0.02 & -0.31 & 129 \\
Audit or finance committee & 0.55 & 0.65 & -0.10 & -1.65 & 129 \\
Past audit or finance committee & 0.46 & 0.33 & 0.12 & 1.99 & 129 \\
Past financial role & 0.21 & 0.16 & 0.05 & 0.95 & 129 \\
Financial firm connection & 0.21 & 0.12 & 0.09 & 1.94 & 129 \\
Financial firm board member & 0.14 & 0.12 & 0.02 & 0.39 & 129 \\
Number of board positions & 1.99 & 1.83 & 0.16 & 0.54 & 129 \\
Number of past board positions & 1.33 & 1.02 & 0.32 & 1.58 & 129 \\
Bank connection & 0.75 & 0.40 & 0.35 & 5.93 & 109 \\
Bank connection - violation & 0.69 & 0.31 & 0.38 & 6.84 & 109 \\
\hline
\end{tabular}




\section{Table 10: Regression of Firm Policies}

This table presents estimates of regressions of investment, financing, payout, volatility and CEO compensation around the time of covenant violations. A covenant violation occurs if the firm violates at least one out of four covenants (current ratio, net worth, tangible net worth, and debt-to-EBITDA) during the year in at least one quarter. The firm-level control variable is firm size (log). New appointment is a (treatment group) dummy variable that takes a value of one if there is an increase in the number of independent directors between year 0 (the violation year) and year 2. After is a dummy variable that takes a value of one in the post-violation period. Panel A presents estimates in which the dependent variable is capital expenditures (scaled by lagged property, plant and equipment), net debt issues, net equity issues, SEO proceeds, changes in dividends (all scaled by lagged total assets), and changes in the standard deviation (annualized) of return on assets (ROA) over the last eight quarters. Panel B presents estimates in which the dependent variable is the logarithm of CEO total pay, salary, bonus, value of option grants (grant-date Black-Scholes value) or value of restricted stock grants (grant-date fair value). The sample consists of annual observations on Investor Responsibility Research Center (IRRC) non-financial firms from 1994 to 2008 for which syndicated loans data are available from DealScan. The sample includes years $-3,-2$, and -1 before the violation, and years 2,3 , and 4 after the violation. Refer to Table A1 in the Appendix for variable definitions. Robust $t$-statistics adjusted for firm-level clustering are in parentheses. $*, * *, * * *$ indicates significance at the $10 \%, 5 \%$, and $1 \%$ levels.

Panel A: Investment, Financing, Payout and Volatility

\begin{tabular}{|c|c|c|c|c|c|c|}
\hline & $\begin{array}{c}\text { Investment } \\
(1)\end{array}$ & $\begin{array}{c}\text { Net debt } \\
\text { issues } \\
(2)\end{array}$ & $\begin{array}{c}\text { Net equity } \\
\text { issues } \\
(3)\end{array}$ & $\begin{array}{c}\text { SEO } \\
\text { proceeds } \\
(4)\end{array}$ & $\begin{array}{c}\text { Dividends } \\
(5)\end{array}$ & $\begin{array}{c}\text { Volatility } \\
\text { of ROA } \\
(6)\end{array}$ \\
\hline New appointment $\times$ After & $\begin{array}{l}0.081 \\
(1.60)\end{array}$ & $\begin{array}{l}0.028 \\
(1.09)\end{array}$ & $\begin{array}{c}0.037^{*} \\
(1.77)\end{array}$ & $\begin{array}{c}0.035^{* *} \\
(1.99)\end{array}$ & $\begin{array}{c}-0.002^{* *} \\
(-2.51)\end{array}$ & $\begin{array}{c}-0.007^{* *} \\
(-2.01)\end{array}$ \\
\hline After & $\begin{array}{c}-0.066^{*} \\
(-1.92)\end{array}$ & $\begin{array}{c}-0.086^{* *} \\
(-2.11)\end{array}$ & $\begin{array}{l}0.034 \\
(1.26)\end{array}$ & $\begin{array}{l}0.007 \\
(0.23)\end{array}$ & $\begin{array}{l}0.000 \\
(0.41)\end{array}$ & $\begin{array}{l}-0.002 \\
(-0.24)\end{array}$ \\
\hline Firm level controls & Yes & Yes & Yes & Yes & Yes & Yes \\
\hline Firm fixed effects & Yes & Yes & Yes & Yes & Yes & Yes \\
\hline Year fixed effects & Yes & Yes & Yes & Yes & Yes & Yes \\
\hline$R^{2}$ & 0.132 & 0.100 & 0.045 & 0.056 & 0.090 & 0.087 \\
\hline Number of observations & 697 & 697 & 697 & 697 & 678 & 652 \\
\hline Number of firms & 118 & 118 & 118 & 118 & 118 & 118 \\
\hline
\end{tabular}

Panel B: CEO Compensation

\begin{tabular}{|c|c|c|c|c|c|}
\hline & $\begin{array}{c}\text { CEO } \\
\text { Total pay (log) } \\
(1)\end{array}$ & $\begin{array}{c}\text { CEO } \\
\text { Salary (log) } \\
(2)\end{array}$ & $\begin{array}{c}\text { CEO } \\
\text { Bonus (log) } \\
(3)\end{array}$ & $\begin{array}{c}\text { CEO } \\
\text { Option (log) } \\
(4)\end{array}$ & $\begin{array}{c}\text { CEO } \\
\text { Stock (log) } \\
(5)\end{array}$ \\
\hline New appointment $\times$ After & $\begin{array}{l}0.134 \\
(1.28)\end{array}$ & $\begin{array}{l}-0.041 \\
(-0.82)\end{array}$ & $\begin{array}{c}-0.641^{* * *} \\
(-2.62)\end{array}$ & $\begin{array}{c}0.510^{* *} \\
(2.00)\end{array}$ & $\begin{array}{l}0.051 \\
(0.13)\end{array}$ \\
\hline After & $\begin{array}{l}-0.220 \\
(-1.33)\end{array}$ & $\begin{array}{l}0.065 \\
(0.96)\end{array}$ & $\begin{array}{c}0.365^{*} \\
(1.72)\end{array}$ & $\begin{array}{c}-0.774^{* *} \\
(-2.35)\end{array}$ & $\begin{array}{c}-0.760^{* *} \\
(-2.10)\end{array}$ \\
\hline Firm level controls & Yes & Yes & Yes & Yes & Yes \\
\hline Firm fixed effects & Yes & Yes & Yes & Yes & Yes \\
\hline Year fixed effects & Yes & Yes & Yes & Yes & Yes \\
\hline$R^{2}$ & 0.218 & 0.301 & 0.184 & 0.136 & 0.395 \\
\hline Number of observations & 660 & 663 & 485 & 413 & 227 \\
\hline Number of firms & 118 & 118 & 117 & 110 & 80 \\
\hline
\end{tabular}




\section{Figure 1: Ratio of Independent to Non-Independent Directors}

This figure shows the cross-sectional average and 95\% confidence interval of the ratio of independent to nonindependent directors in the four years before and after a covenant violation. A covenant violation occurs if the firm violates at least one out of four covenants (current ratio, net worth, tangible net worth, and debtto-EBITDA) during the year in at least one quarter. The sample consists of annual observations on Investor Responsibility Research Center (IRRC) non-financial firms from 1994 to 2008 for which syndicated loans data are available from DealScan.

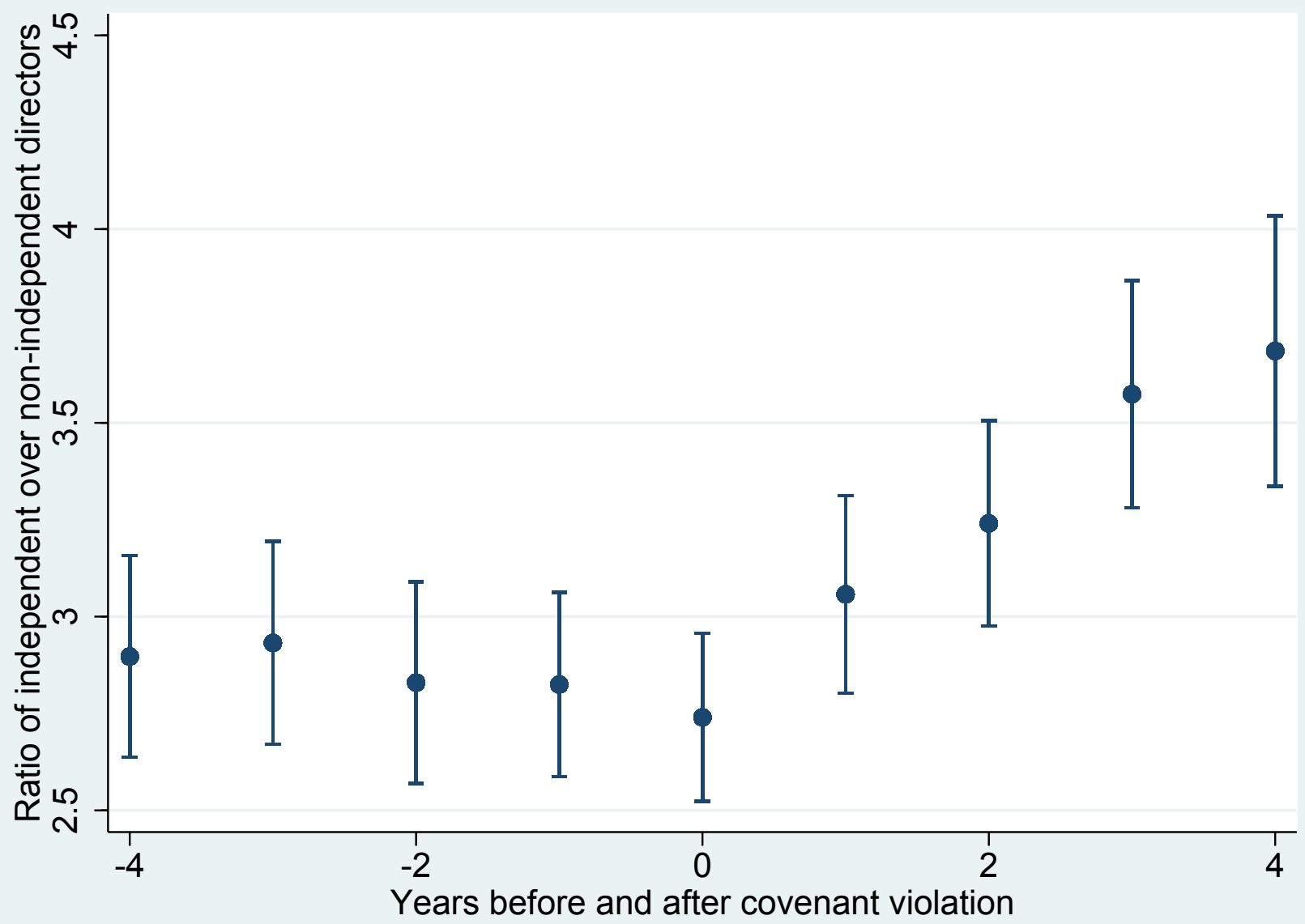




\section{Figure 2: Number of Independent Directors and Binding Distance to Covenant Threshold}

This figure shows nonparametric regression estimates of the number of independent directors (two years after violation) on the relative binding distance to the covenant threshold. A covenant violation occurs if the firm violates at least one out of four covenants (current ratio, net worth, tangible net worth, and debt-to-EBITDA) during the year in at least one quarter. Panel A presents estimates using all covenant violations, and Panel B presents estimates using only the first covenant violation for each firm. The sample consists of annual observations on Investor Responsibility Research Center (IRRC) non-financial firms from 1994 to 2008 for which syndicated loans data are available from DealScan.

Panel A: All Violations

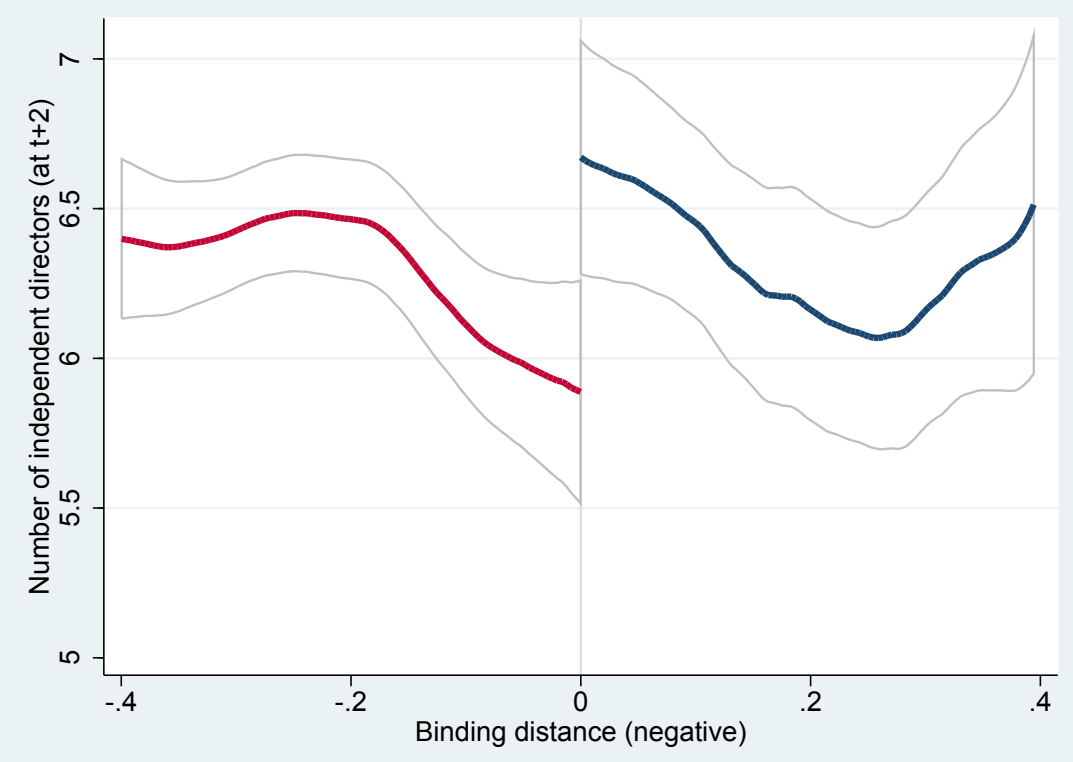

Panel B: First Violations

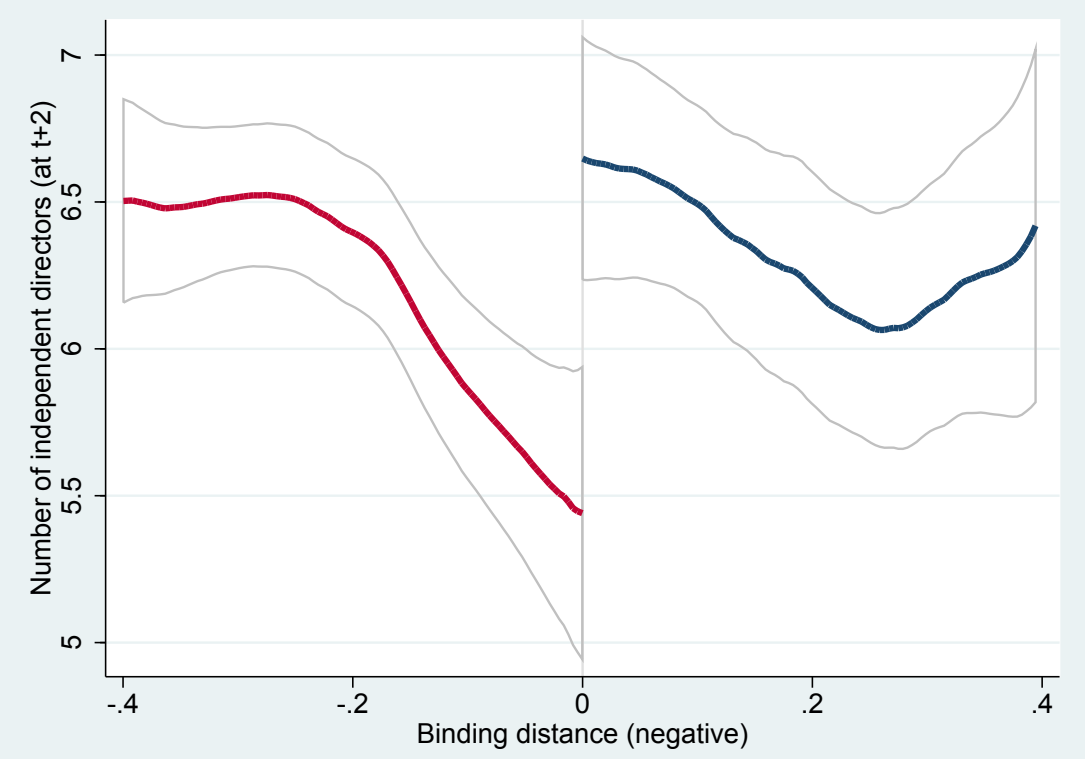




\section{Table A1: Variable Definitions}

\begin{tabular}{|c|c|}
\hline Variable & Definition \\
\hline Number of independent directors & Number of board members that are independent directors (IRRC). \\
\hline Number of non-independent directors & Number of board members that are non-independent directors (IRRC). \\
\hline Number of directors & Number of board members (IRRC). \\
\hline Number of connected directors & $\begin{array}{l}\text { Number of board members that have a board or non-board position in another firm with outstand- } \\
\text { ing loans that have at least one bank (lead arranger or other participant) in common with the } \\
\text { firm's current banks (BoardEx). }\end{array}$ \\
\hline Number of non-connected directors & $\begin{array}{l}\text { Number of board members that do not have a board or non-board position in another firm with } \\
\text { outstanding loans that have at least one bank (lead arranger or other participant) in common with } \\
\text { the firm's current banks (BoardEx). }\end{array}$ \\
\hline Covenant violation & $\begin{array}{l}\text { Dummy variable that takes a value of one if the firm violates at least one out of four covenant } \\
\text { (current ratio, net worth, tangible net worth and debt-to-EBITDA) during the year in at least one } \\
\text { quarter, and zero otherwise (DealScan). }\end{array}$ \\
\hline Current ratio & Ratio of current assets to current liabilities in each quarter (Compustat ACTQ / LCTQ). \\
\hline Net worth & Total assets minus total liabilities in each quarter in $\$$ millions (Compustat ATQ - LTQ). \\
\hline Tangible net worth & $\begin{array}{l}\text { Tangible assets minus total liabilities in each quarter in } \$ \text { millions (Computstat ACTQ }+ \text { AOQ }+ \\
\text { PPENTQ - LTQ). }\end{array}$ \\
\hline Debt-to-EBITDA & $\begin{array}{l}\text { Ratio of total debt (long-term debt plus debt in current liabilities) to earnings before interest, taxes, } \\
\text { depreciation, and amortization (sum of four most recent fiscal quarters) (Compustat (DLTTQ + } \\
\text { DLCQ) / (NIQ - XIQ + TXTQ + XINTQ + DPQ)). }\end{array}$ \\
\hline Interest coverage & $\begin{array}{l}\text { Ratio of earnings before interest, taxes, depreciation, and amortization to interest expenses (sum } \\
\text { of four most recent fiscal quarters) (Compustat (NIQ - XIQ + TXTQ + XINTQ + DPQ) } \\
\text { XINTQ). }\end{array}$ \\
\hline Firm size & Total assets in $\$$ millions (Compustat AT). \\
\hline Leverage & $\begin{array}{l}\text { Ratio of total debt (long-term debt plus debt in current liabilities) to total assets (Compustat } \\
\text { (DLTT + DLC) / AT). }\end{array}$ \\
\hline Firm as & Number of years since the stock inclusion in the CRSP database. \\
\hline Number of segments & Number of business segments in which firm operates (Compustat). \\
\hline Market-to-book & $\begin{array}{l}\text { Ratio of market value of assets (total assets plus market value of equity minus book value of equity) } \\
\text { to total assets (Compustat }(\mathrm{AT}+\mathrm{CSHO} \times \text { PRCC_F }-\mathrm{CEQ}) / \mathrm{AT}) \text {. }\end{array}$ \\
\hline$R \& D$ & Ratio of research and development expenditures to total assets (Compustat XRD / AT). \\
\hline Stock return volatility & Standard deviation (annualized) of returns estimated with daily stock returns (CRSP). \\
\hline Free cash flow & $\begin{array}{l}\text { Ratio of earnings before interest, taxes, depreciation, and amortization minus capital expenditures } \\
\text { to total assets (Compustat (EBITDA - CAPX) / AT). }\end{array}$ \\
\hline Return on assets & $\begin{array}{l}\text { Ratio of earnings before interest, taxes, depreciation, and amortization to total assets (Compustat } \\
\text { EBITDA / AT). }\end{array}$ \\
\hline Governance index & $\begin{array}{l}\text { Governance index of Gompers, Ishii, and Metrick (2003), which is based on } 24 \text { antitakeover provi- } \\
\text { sions (IRRC). }\end{array}$ \\
\hline Stock return & Annual stock return for the fiscal year (CRSP). \\
\hline
\end{tabular}




\begin{tabular}{|c|c|}
\hline Variable & Definition \\
\hline Investment & $\begin{array}{l}\text { Ratio of capital expenditures to lagged net property, plant and equipment (Compustat CAPEX / } \\
\text { PPENT). }\end{array}$ \\
\hline Net debt issues & $\begin{array}{l}\text { Ratio of long term net debt issues (issuance minus reduction of debt) proceeds to lagged total } \\
\text { assets (Compustat (DLTIS - DLTR) / AT). }\end{array}$ \\
\hline Net equity issues & $\begin{array}{l}\text { Ratio of net equity proceeds (issuance minus purchases of stock) to lagged total assets (Compustat } \\
\text { (SSTK - PRSTKC) / AT). }\end{array}$ \\
\hline SEO proceeds & Ratio of SEO proceeds (SDC New Issues) to lagged total assets (Computstat AT). \\
\hline Dividends & atio of common dividends to lagged total assets (Compustat DVC / AT). \\
\hline Volatility of ROA & tandard deviation (annualized) of return on assets over the last eight quarters (Compustat). \\
\hline CEO total pay & Total CEO compensation in $\$$ thousands (Execucomp TDC1). \\
\hline CEO salary & CEO salary in $\$$ thousands (Execucomp SALARY). \\
\hline CEO bonus & CEO bonus in $\$$ thousands (Execucomp BONUS). \\
\hline CEO option & $\begin{array}{l}\text { Value of option grants to the CEO based on grant-date Black-Scholes value in } \$ \text { thousands (Exe- } \\
\text { cucomp OPTION_AWARDS_BLK_VALUE). }\end{array}$ \\
\hline CEO stock & $\begin{array}{l}\text { Value of restricted stock grants to the CEO based on grant-date fair value in } \$ \text { thousands (Execu- } \\
\text { comp STOCK_AWARDS_FV). }\end{array}$ \\
\hline CEO o & umber of shares held by the CEO divided by number of shares outstanding (ExecuComp). \\
\hline CEO & Number of years since the date the director became CEO (Exe \\
\hline Male & (BoardEx). \\
\hline Age & ins the board (BoardEx). \\
\hline MBA & $\begin{array}{l}\text { Dummy variable that takes a value of one if a director holds an MBA when he joins the board, } \\
\text { and zero othwerwise (BoardEx). }\end{array}$ \\
\hline Financial e & $\begin{array}{l}\text { Dummy variable that takes a value of one if a director has a financial education when he joins the } \\
\text { board, defined as a degree in the field of economics, accounting, finance, management, and zero } \\
\text { otherwise (BoardEx). }\end{array}$ \\
\hline Audit or finance committee & $\begin{array}{l}\text { Dummy variable that takes a value of one if a director is a member of the finance or audit com- } \\
\text { mittees, and zero otherwise (BoardEx). }\end{array}$ \\
\hline Past audit or finance committee & $\begin{array}{l}\text { Dummy variable that takes a value of one if a director has been a member of the finance or audit } \\
\text { committee based on past work experience, and zero otherwise (BoardEx). }\end{array}$ \\
\hline Past financial role & $\begin{array}{l}\text { Dummy variable that takes a value of one if a director has held a financial role (CFO, finance } \\
\text { director, treasury, accountant) based on past work experience, and zero otherwise (BoardEx). }\end{array}$ \\
\hline Financial firm cc & $\begin{array}{l}\text { Dummy variable that takes a value of one if a director has held a position in a financial firm (SIC } \\
6000-6999 \text { ) based on past work experience, and zero otherwise (BoardEx). }\end{array}$ \\
\hline Financial firm boa & $\begin{array}{l}\text { Dummy variable that takes a value of one if a director has held a board position in a financial firm } \\
\text { (SIC 6000-6999) based on past work experience, and zero otherwise (BoardEx). }\end{array}$ \\
\hline Num & mber of board positions held by a director (BoardEx). \\
\hline Number of past boards positions & Number of board positions a director has held based on past work experience (BoardEx). \\
\hline Bank connection & $\begin{array}{l}\text { Dummy variable that takes a value of one if a director has a board or non-board position in another } \\
\text { firm with outstanding loans that have at least one bank (lead arranger or other participant) in } \\
\text { common with the firm's current banks (BoardEx). }\end{array}$ \\
\hline Bank connection - violation & $\begin{array}{l}\text { Dummy variable that takes a value of one if a director has a board or non-board position in another } \\
\text { firm with outstanding loans that have at least one bank (lead arranger or other participant) in } \\
\text { common with the firm's banks in the syndicate of the loan for which a violation occurs (BoardEx). }\end{array}$ \\
\hline
\end{tabular}




\title{
Internet Appendix for "Creditor Control Rights and Board Independence"
}

\author{
Daniel Ferreira* $\quad$ Miguel A. Ferreira ${ }^{\dagger} \quad$ Beatriz Mariano*
}

June 14, 2017

${ }^{*}$ London School of Economics, CEPR and ECGI. Email: D.Ferreira@lse.ac.uk.

${ }^{\dagger}$ Nova School of Business and Economics, CEPR and ECGI. Email: miguel.ferreira@novasbe.pt.

${ }^{\ddagger}$ Cass Business School. Email: Beatriz.Mariano@city.ac.uk. 


\section{A Examples}

There is anecdotal evidence that creditors demand changes to board composition as a consequence of credit renegotiations. We search Forms 8-K and 10-Q, and press releases for examples in which lenders contractually demand changes. Although the language used does not say that lenders have the right to nominate directors (probably because of issues with lender liability), the contracts often say that the new directors have to be "acceptable to the lenders."

\section{A.1 Quadrant 4 System Corporation}

This is an example of explicit credit intervention in the board nomination process. The appointment occurs one year after the agreement to appoint directors.

The company (Quadrant 4 System Corporation) and its lender (BMO) entered into a forbearance agreement effective March 17, 2016. Under the terms of the forbearance agreement, "the Forbearance Parties have agreed to, among other things,..., appoint three new members to the Company's Board of Directors."

"On March 16, 201\%, the Company's Board of Directors (the Board) appointed Robert H. Steele, Brad Buxton, and Michael Silverman to fill its three current vacancies. There are no understandings or arrangements between Messrs. Steele, Buxton, or Silverman and any other person to which Messrs. Steele, Buxton, or Silverman was selected as a director of the Com-

pany; provided, however that as a condition of BMOs agreement to enter into the Forbearance Agreement, BMO required that the Company appoint three new directors who were acceptable to the Board and to BMO."

Note that the three directors were appointed exactly one (calendar) year after the agreement.

\section{A.2 RCS Capital Corporation}

This is also an example of explicit credit intervention in the board nomination process. Here the appointment occurs five days after the agreement, but in a new fiscal year.

"RCS Capital Corporation (the "Company") and the other Loan Parties (defined therein) have entered into a forbearance agreement, dated as of December 31, 2015 (the "First Lien Forbearance Agreement"), with the lenders party" 
"Pursuant to requirements under the First Lien Forbearance Agreement and the Second Lien Forbearance Agreement for the appointment of an independent director reasonably acceptable to such lenders, on December 30, 2015, the board of directors (the "Board") of the Company appointed Bradley E. Scher as a director of the Company and the Chairman of the Executive Committee of the Board effective as of January 4, 2016."

Although the director was appointed only five days after the agreement, the appointment occurred in the new fiscal year.

\section{A.3 Peekay Boutiques Inc.}

This is also an example of explicit credit intervention in the board nomination process. In this example, after a covenant violation, there are a series of contract amendments that eventually lead to the appointment of an independent director. The appointment occurs two years after the first covenant violation.

December 31, 2012: The company (Peekay Boutiques Inc.) entered into a financing agreement with a group of lenders.

March 31, 2014: The company obtains a first amendment to the agreement, which includes a covenant waiver.

Between March 31, 2014, and February 22, 2016: The company obtains eight successive amendments to the agreement. These amendments include multiple covenant waivers, and increasingly stricter conditions.

February 22, 2016: the company enters into a forbearance agreement, which, among other things, requires that:

"The company must appoint an independent director nominated by the Consenting Term A Lenders to the Board of Directors of the Company and the applicable equivalent Board of each of the Company's subsidiaries. On February 22, 2016, the Loan Parties appointed Matthew R. Khan as independent director in satisfaction of this requirement."

The appointment was effective on February 24, 2016, two years after the first covenant waiver. 


\section{A.4 Saratoga Resources, Inc.}

This is also an example of explicit credit intervention in the board nomination process.

"Saratoga Resources, Inc. today announced that it has appointed Richard Nevins to its board of directors and as a member of the board's existing independent committee."

"Mr. Nevins' appointment was made pursuant to the terms of the amendment to the existing forbearance agreement with the Company's senior lenders. Under that amendment, if an additional independent director acceptable to the lenders was appointed to the board and independent committee, the forbearance period would be extended until May 22, 2015. By separate agreement, the lenders agreed to extend the forbearance period until June 5, 2015."

\section{A.5 Hooper Holmes, Inc.}

This is a case in which a covenant violations is closely linked to the appointment of new independent directors, although no direct link is mentioned. In July 2006, the company reports an agreement with lenders relative to actual and expected covenant violations, and the addition of a new independent director.

"Hooper Holmes, Inc. (the "Company") has agreed to the terms of a Notice of Default, Reservation of Rights and Amendatory Letter (Amended and Restated) to its Amended and Restated Credit Agreement. The letter, provided by Wachovia Bank, National Association, as agent and lender under the credit agreement, was prompted by the Company's seeking a waiver from its lenders of actual and likely future violations of certain financial covenants set forth in the credit agreement."

"Although the lenders are not granting a waiver of the covenant violations, they have agreed

to forbear from terminating the credit commitments under the credit agreement, declaring all credit obligations immediately due and payable, and exercising their rights and remedies under the credit agreement, until the earlier of (i) the expiration of the Forbearance Period, or (ii) the occurrence of an event of default under the credit agreement other than the actual or anticipated violations of the financial covenants described above."

The original date of the letter was July 13, 2006. "On July 27, 2006, the Board of Directors of the Company (the "Board"), acting upon the recommendation of the Governance and Nom- 
inating Committee, elected John W. Remshard as a director, effective immediately. The Board also appointed Mr. Remshard to the Audit Committee of the Board. There is no arrangement or understanding between Mr. Remshard and any other persons under which he was selected as a director."

A press release reports "John brings a wealth of knowledge and wisdom from having led the turnaround of Empire Blue Cross Blue Shield from a bankrupt nonprofit to a highly successful public company with a market capitalization of $\$ 6.5$ billion."

\section{A.6 Akorn, Inc.}

This is an example of explicit credit intervention in the workings of the board, without requiring the appointment of a new director. The forebearance agreement with the lenders required the company to hire a particular consulting firm to " assist in the development and execution of its restructuring plan and provide oversight and direction to the Company's day-to-day operations."

"During the Company's discussion with the Consultant, the Company agreed to establish a special committee of the board (the "Corporate Governance Committee") (...). The Consultant will interface with the Corporate Governance Committee regarding the Company's reestructuring actions."

\section{B Robustness}

We perform several robustness checks of our primary findings. First, we consider Poisson regressions that take into account the count nature of the dependent variable (number of independent directors). These regressions assume that $y_{i t}$ is independently Poisson distributed with conditional mean equal to

$$
E\left[y_{i t} \mid v_{i t-2}, D_{i t-2}, \alpha_{t}, f_{i}\right]=\exp \left\{\beta v_{i t-2}+\sum_{p=1}^{P}\left[\gamma_{p 0}+\gamma_{p 1} v_{i t-2}\right] D_{i t-2}^{p}+\alpha_{t}+f_{i}\right\}
$$

Parameter $\beta$ is again a semi-elasticity, and thus, it can be directly compared to the previous estimates. We report the results in column (1) of Table IA.12. The Poisson regression yields an estimate of $\beta$ that is just slightly lower (19\%) than those from log-linear regressions. 
Second, we consider the possibility that director appointments are simply a consequence of CEO turnover. Nini, Smith, and Sufi (2012) show that violations lead to more CEO turnover. Thus, it is possible that new CEOs bring new directors to the board. If this is the case, the effect of covenants on board independence could still be causal but perhaps less interesting because this would simply be a side effect of another result that has already been documented in the literature. To address this possibility, we drop from the sample all observations in years in which a CEO is replaced and in the two years thereafter. Table IA.12, column (2), reports the results. If anything, the estimated effect is stronger, at 30\%, when using a sample of firms without CEO turnover. Table IA.13 in the Internet Appendix presents estimates using alternative samples of firms without CEO turnover.

Third, we consider an alternative measure of the implied covenant violation indicator excluding debt-to-EBITDA covenants. This is likely to add noise to our estimates (debt-to-EBITDA violations are associated with $84 \%$ of the violations in our full sample). Table IA.12, column (3), reports the results. The estimate remains qualitatively similar (18\%) to those in Table 3 , but it is statistically weaker. We conclude that including debt-to-EBITDA covenants is important for estimating the effects of violations with precision, but we find qualitatively similar results even when we ignore debt-to-EBITDA covenants. In column (4) of Table IA.12, we add interest coverage covenants to our list of covenants (i.e., our binding distance variable now considers five different covenants). Adding new covenants changes the definition of the discontinuity sample because the number and the types of covenants affect the calculation of the binding distance. The introduction of interest coverage covenants has only a minor impact on the estimated $\beta$, which is now 0.20 and statistically significant. Table IA.14 in the Internet Appendix replicates all specifications in Table 3 when including the interest coverage covenant.

Fourth, we consider alternative sample periods. In columns (5) and (6) of Table IA.12, we divide the sample into observations before and after the Sarbanes-Oxley Act (SOX) of 2002, which, among other things, mandated more independent boards. We find strikingly similar estimates for both the pre- and post-SOX subsamples (20\% and 21\%, respectively). Despite the significant reduction in sample size, the effects remain statistically significant. In column (7) of Table IA.12, we extend our sample to include observations after 2008, up to 2014. We replicate our main specification using the extended sample and find an estimated $\beta$ of 0.17 
$(t=3.57)$. Adding observations from 2009 to 2014 has a small impact on the magnitude of the estimated effects, but overall, the estimated effects are similar and remain statistically significant. Table IA.15 in the Internet Appendix replicates all specifications in Table 3 when using the extended sample.

Finally, in column (8) of Table IA.12 we replace the number of independent directors with the ratio of the number of independent directors to board size. We find that violations reduce the fraction of independent directors by 16\%, which is equivalent to 11 percentage points when evaluated at the sample average (70\%). Table IA.16 in the Internet Appendix provides additional estimates using the fraction of independent directors as the outcome variable.

Table IA.17 shows estimates of the regression in equation (3) using either one or three lags instead of two lags. Using one lag, the effects are economically weaker but can still be detected (statistically significant in some but not all specifications). This is expected because the process of appointing directors may take time. When using three lags, the effects are similar to those obtained with two lags and are typically economically and statistically significant. However, the three-lag effects are less statistically precise because of the reduction in sample size. Table IA.18 shows estimates of the regression in equation (3) in which the covenant violation dummy is defined using calendar year (in alternative to fiscal year) as there may be a mismatch between the actual violation year and its fiscal year. This generates a different timing for director appointments. The effects are statistically and economically significant for all lags. Table IA.19 shows estimates of the regression in equation (3) including the annual stock return as a control variable to further control for past market performance.

For our baseline results, we adopt a conservative criterion to determine which observations to retain in the discontinuity sample. According to this criterion, an observation is retained only if, for each quarter of the year, the quarterly binding distance falls inside the interval. Table IA.20 shows that our results are robust to a less stringent criterion in which we only require the annual binding distance to lie within the interval.

\section{B.1 Who are the directors appointed after covenant violations?}

We construct two alternative control groups. In the first of these groups, we match each new director to a randomly chosen independent director retained by the same firm for at least two 
years after the first violation. Panel A of Table IA.22 reports the average director characteristics using this alternative control group. This choice of control group - retained directors - is a conservative one. If creditors do indeed influence board composition, they may support the retention of connected directors after a violation. This control group allows us to match a higher number of directors (223). Compared to this control group, newly appointed directors are younger, more likely to have a finance-related degree, and more likely to have past experience in a financial role. In addition, the difference between the two groups in terms of connections to current banks is $21 \%$ and statistically significant $(t=4.58)$. For connections via a bank in the syndicate of the loan for which a violation occurs, the difference is $17 \%(t=3.56)$.

Panel B of Table IA.22 reports the average director characteristics using a second alternative control group. The control group now includes independent directors who are members of the board in the two years before the first violation and remained on the board for at least two years after the violation. This control group allows us to match an even higher number of directors (226). The results are consistent with those in Panels A and B. The difference between the two groups in terms of connections to current banks is $32 \%(t=6.31)$.

We conclude that new directors appointed after violations are likely to have connections to creditors. The large majority of these connections occur through the banks of loans for which there is a violation. These connections are unlikely to be chance events; connections via banks in syndicated loans are infrequent in the control groups.

\section{B.2 Which firms appoint new directors after covenant violations?}

Not all firms are likely to respond to loan covenant violations in the same way. Whether firms experience major or minor board changes after violations depends on the reason that such changes occur. For example, if lenders (directly or indirectly) promote board changes, we expect to find large effects among firms that have closer relationships with their lenders. In contrast, if lenders are indifferent to board composition, the effect of violations on board composition should be independent of the identity of lenders. To test for the hypothesized differential board responses, we expand the specification in equation (3) by interacting the covenant violation indicator with a particular proxy and examining the effect of each proxy in a separate regression. The dependent variable is the logarithm of the number of independent 
directors, and the regressions include firm and year fixed effects (as in column (1) of Table 3).

Panel A of Table IA.24 presents the results for the lending relationship proxies. We first consider the impact of relationship lending on the effect of violations on board appointments. For each loan in our sample, we first identify the lead arranger and then count the number of past term loans that a borrower has obtained from the same lead arranger. We then create an indicator of whether the borrower has at least two historical lending relationships with its current lead arranger (past loans $\geq 2$; 302 observations) and an indicator of whether the borrower has no historical lending relationship or only one (past loans $<2$; 363 observations). Column (1) shows that the estimated $\beta$ is $32 \%$ for borrowers with more historical lending relationships and just $13 \%$ (statistically insignificant) for borrowers with no such relationships. The difference-19\% - is statistically significant at the $10 \%$ level. Column (2) shows similar estimates when we include firm-level control variables.

In columns (3) and (4), we use all loans (i.e., term loans and credit lines) to count the number of past loans that a borrower has obtained from the same lead arranger. We then create an indicator of whether the borrower has at least five historical lending relationships with its current lead arranger (past loans $\geq 5 ; 227$ observations) and an indicator of whether the borrower has fewer than five historical lending relationships (past loans $<5 ; 438$ observations). We again find a larger violation effect for the group of borrowers with more historical lending relationships. The effect for the group of borrowers with fewer historical lending relationships is smaller, but the difference between the two groups is not statistically significant.

Firms without credit ratings are more dependent on bank debt, which makes banks more powerful in negotiations at the time of covenant violations. Furthermore, in the absence of public debt markets and ratings agency monitoring, lender monitoring of unrated firms may be more important. These reasons suggest a stronger effect of violations on the appointment of new directors in unrated firms. However, unrated firms may find it difficult to recruit new directors, as these firms are likely to be more opaque and have a weaker financial position. Columns (5) and (6) present the estimated coefficients for rated firms (406 observations) and unrated firms (259 observations). We find that the violation effect is stronger for unrated firms than for rated firms. The difference is economically sizable (23\% with control variables), but it is not statistically significant. 
Creditors' bargaining power after violations is tempered by cross-default and cross-acceleration provisions because such provisions reduce creditors' incentives to declare a borrower in default. This is, however, less of a concern if the borrower's other loans are relatively small, that is, if a single loan constitutes most of the borrower's debt. To construct a proxy for debt concentration, we create an indicator of whether the firm needs to repay at least one large loan (large loan; 450 observations) and an indicator for all other cases (small loan). We consider a loan to be large if the ratio of the loan amount to total assets at origination is above the median. Panel B of Table IA.24, columns (1) and (2), presents the results. We find that the effect is stronger for the large loan group than that for those cases with no such loans. The $17 \%$ difference between the two groups (in column (1)) is statistically significant at the $10 \%$ level. In addition, columns (3) and (4) show that the effect is stronger for the group of loans with shorter maturity (i.e., the residual loan maturity is below the median) than for the group of loans with longer maturity. This result is consistent with the idea that creditors' bargaining power is likely to be greater when the firm has the need to refinance or renegotiate loans that are soon to come due.

Finally, in Panel B of Table IA.23, columns (5)-(8), we consider the effect of covenant slack at loan origination on the impact of violations on board independence. The evidence in Demiroglu and James (2010) motivates this analysis. They show that firms with tighter covenants at origination experience less significant changes in investment and debt issuance after violations. A possible explanation is that borrowers are more likely to agree to tight covenants when they expect violations to have little impact on investment and financial policy. A similar logic may apply to our setup: Managers and incumbent directors might be more reluctant to agree to tight covenants if they expect creditors to use violations to force changes in board structure.

We measure covenant tightness by the binding distance and tightness at origination, as described in Section 1. Using either measure, we find that the effect of violations on board appointments is stronger in those firms with less tight covenants at origination (high binding distance and high tightness groups). The differences between the two groups are economically significant at $16 \%$ and $20 \%$ in columns (6) and (8) with control variables but not sufficiently precise to be statistically significant. 
Overall, the evidence shows that the impact of violations on board appointments is economically stronger in firms for which we would expect more creditor intervention after violations. These are firms that regularly borrow from the same banks, firms that have one large loan, firms without credit ratings, and firms with less tight covenants at loan origination. 


\section{Table IA.1: Comparison with DealScan, IRRC and Compustat Samples}

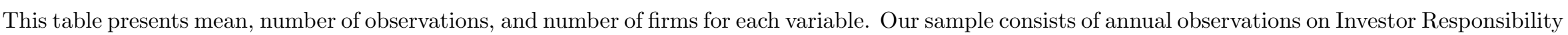

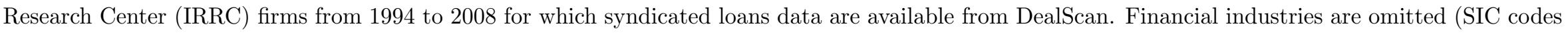

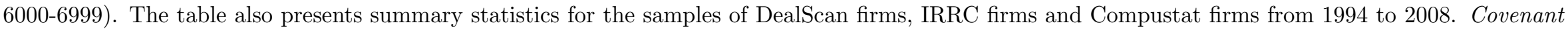

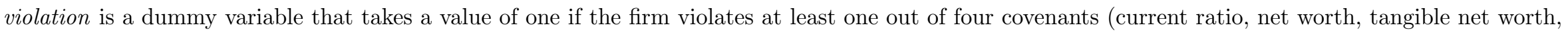

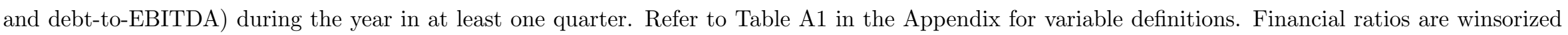
at the bottom and top $1 \%$ level.

\begin{tabular}{|c|c|c|c|c|c|c|c|c|c|c|c|c|}
\hline & \multicolumn{3}{|c|}{ Our sample } & \multicolumn{3}{|c|}{ DealScan sample } & \multicolumn{3}{|c|}{ IRRC sample } & \multicolumn{3}{|c|}{ Compustat sample } \\
\hline & Mean & $\begin{array}{l}\text { Number } \\
\text { of obs. }\end{array}$ & $\begin{array}{l}\text { Number } \\
\text { of } \\
\text { firms }\end{array}$ & Mean & $\begin{array}{l}\text { Number } \\
\text { of obs. }\end{array}$ & $\begin{array}{l}\text { Number } \\
\text { of } \\
\text { firms }\end{array}$ & Mean & $\begin{array}{l}\text { Number } \\
\text { of obs. }\end{array}$ & $\begin{array}{l}\text { Number } \\
\text { of } \\
\text { firms }\end{array}$ & Mean & $\begin{array}{l}\text { Number } \\
\text { of obs. }\end{array}$ & $\begin{array}{l}\text { Number } \\
\text { of } \\
\text { firms }\end{array}$ \\
\hline Number of independent directors & 6.39 & 2,801 & 597 & - & - & - & 6.54 & 9,201 & 1,574 & - & - & - \\
\hline Number of non-independent directors & 2.76 & 2,801 & 597 & - & - & - & 2.89 & 9,201 & 1,574 & - & - & - \\
\hline Ratio of indep. to non-indep. directors & 3.45 & 2,801 & 597 & - & - & - & 3.43 & 9,201 & 1,574 & - & - & - \\
\hline Number of directors & 9.15 & 2,801 & 597 & - & - & - & 9.43 & 9,201 & 1,574 & - & - & - \\
\hline Firm size ( $\$$ millions $)$ & 3,542 & 2,801 & 597 & 1,534 & 11,021 & 2,603 & 5,078 & 9,201 & 1,574 & 1,394 & 52,447 & 8,665 \\
\hline Leverage & 0.25 & 2,801 & 597 & 0.27 & 11,021 & 2,603 & 0.23 & 9,201 & 1,574 & 0.22 & 52,447 & 8,665 \\
\hline Firm age & 22.56 & 2,801 & 597 & 14.18 & 11,021 & 2,603 & 26.58 & 9,201 & 1,574 & 13.51 & 52,447 & 8,665 \\
\hline Number of segments & 2.88 & 2,801 & 597 & 2.28 & 11,021 & 2,603 & 2.77 & 9,201 & 1,574 & 1.90 & 52,447 & 8,665 \\
\hline Market-to-book & 1.88 & 2,801 & 597 & 1.77 & 11,021 & 2,603 & 2.05 & 9,201 & 1,574 & 2.17 & 52,447 & 8,665 \\
\hline R\&D & 0.02 & 2,801 & 597 & 0.02 & 11,021 & 2,603 & 0.03 & 9,201 & 1,574 & 0.06 & 52,447 & 8,665 \\
\hline Stock return volatility & 0.38 & 2,801 & 597 & 0.50 & 11,021 & 2,603 & 0.36 & 9,201 & 1,574 & 0.58 & 52,447 & 8,665 \\
\hline Free cash flow & 0.09 & 2,801 & 597 & 0.05 & 11,021 & 2,603 & 0.09 & 9,201 & 1,574 & -0.04 & 52,447 & 8,665 \\
\hline Return on assets & 0.15 & 2,801 & 597 & 0.12 & 11,021 & 2,603 & 0.15 & 9,201 & 1,574 & 0.02 & 52,447 & 8,665 \\
\hline Governance index & 9.33 & 2,801 & 597 & - & - & - & 9.28 & 9,201 & 1,574 & - & - & - \\
\hline CEO ownership & 0.02 & 2,801 & 597 & - & - & - & 0.02 & 9,201 & 1,574 & - & - & - \\
\hline CEO tenure & 7.51 & 2,801 & 597 & - & - & - & 7.43 & 9,201 & 1,574 & - & - & - \\
\hline Covenant violation & 0.24 & 2,801 & 597 & 0.34 & 11,021 & 2,603 & - & - & - & - & - & - \\
\hline Binding distance & 0.07 & 2,801 & 597 & -0.08 & 11,012 & 2,603 & - & - & - & - & - & - \\
\hline
\end{tabular}




\section{Table IA.2: Covenant Data - Quarterly Frequency}

This table presents mean, standard deviation, minimum, 10th percentile, median, 90th percentile, maximum, number of observations, and number of firms for covenant data. Threshold is the minimum current ratio, net worth and tangible net worth and maximum debt-to EBITDA specified for each covenant across all outstanding loans in each quarter (omitting observations with no threshold data). Binding distance is the relative distance between the actual accounting variable and the corresponding covenant threshold. Tightness is the distance between the actual accounting variable and the corresponding covenant threshold divided by the firm-specific standard deviation of the accounting variable over the full sample period. The sample consists of quarterly observations on Investor Responsibility Research Center (IRRC) non-financial firms from 1994 to 2008 for which syndicated loans data are available from DealScan.

\begin{tabular}{|c|c|c|c|c|c|c|c|c|c|}
\hline & Mean & $\begin{array}{l}\text { Standard } \\
\text { deviation }\end{array}$ & Minimum & $\begin{array}{c}\text { 10th } \\
\text { pctile }\end{array}$ & Median & $\begin{array}{c}\text { 90th } \\
\text { pctile }\end{array}$ & Maximum & $\begin{array}{l}\text { Number } \\
\text { of obs. }\end{array}$ & $\begin{array}{l}\text { Number } \\
\text { of firms }\end{array}$ \\
\hline Current ratio & 2.04 & 1.25 & 0.29 & 0.90 & 1.76 & 3.33 & 11.90 & 11,114 & 597 \\
\hline Net worth (\$ millions) & 1,351 & 5,468 & $-2,612$ & 156 & 514 & 2,505 & 160,000 & 11,199 & 597 \\
\hline Tangible net worth (\$ millions) & 1,331 & 5,344 & $-2,612$ & 155 & 508 & 2,478 & 152,914 & 11,081 & 597 \\
\hline Debt-to-EBITDA & 3.20 & 4.88 & 0.00 & 0.12 & 1.87 & 5.95 & 35.71 & 10,446 & 597 \\
\hline Threshold - current ratio & 1.41 & 0.45 & 0.50 & 1.00 & 1.30 & 2.00 & 3.00 & 808 & 597 \\
\hline Threshold - net worth (\$ millions) & 902 & 6,182 & 5 & 100 & 300 & 1,150 & 180,563 & 3,727 & 597 \\
\hline Threshold - tangible net worth (\$ millions) & 531 & 2,186 & 5 & 55 & 232 & 1,000 & 43,950 & 2,112 & 597 \\
\hline Threshold - debt-to-EBITDA & 3.49 & 1.10 & 0.55 & 2.25 & 3.25 & 5.00 & 11.00 & 6,587 & 597 \\
\hline Binding distance - current ratio & 0.64 & 0.67 & -0.35 & 0.03 & 0.48 & 1.44 & 3.31 & 808 & 597 \\
\hline Binding distance - net worth & 1.08 & 2.48 & -0.29 & 0.14 & 0.52 & 1.65 & 19.03 & 3,727 & 597 \\
\hline Binding distance - tangible net worth & 1.66 & 5.28 & -0.83 & 0.14 & 0.73 & 2.63 & 111.99 & 2,112 & 597 \\
\hline Binding distance - debt-to-EBITDA & 0.16 & 1.20 & -6.49 & -0.42 & 0.44 & 0.95 & 1.00 & 6,587 & 597 \\
\hline Tightness - current ratio & 1.42 & 1.20 & -1.14 & 0.07 & 1.29 & 3.11 & 4.43 & 808 & 597 \\
\hline Tightness - net worth & 0.82 & 0.68 & -0.56 & 0.15 & 0.70 & 1.65 & 3.35 & 3,727 & 597 \\
\hline Tightness - tangible net worth & 0.91 & 0.73 & -0.77 & 0.16 & 0.78 & 1.83 & 3.65 & 2,112 & 597 \\
\hline Tightness - debt-to-EBITDA & 1.00 & 2.55 & -3.35 & -0.42 & 0.40 & 3.37 & 18.85 & 6,587 & 597 \\
\hline
\end{tabular}




\section{Table IA.3: Covenant Data - Quarterly Frequency}

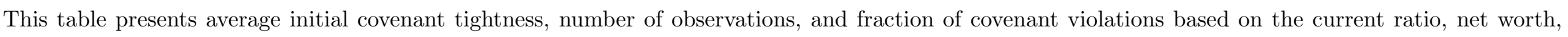

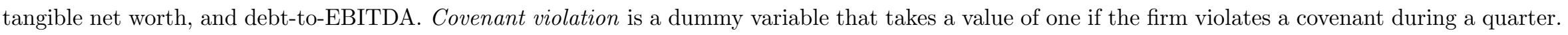

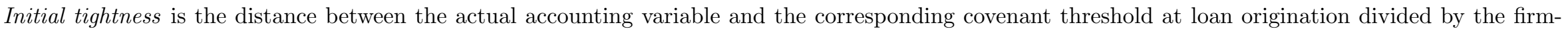

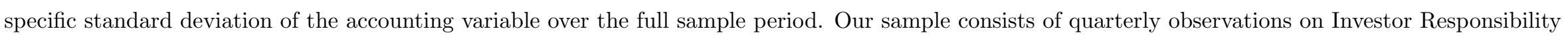

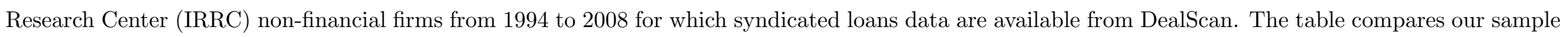
statistics with those in Chava and Roberts (2008).

\begin{tabular}{|c|c|c|c|c|c|c|}
\hline & \multicolumn{3}{|c|}{ Our sample } & \multicolumn{3}{|c|}{ Chava and Roberts (2008) } \\
\hline & $\begin{array}{c}\text { Initial } \\
\text { Tightness }\end{array}$ & $\begin{array}{c}\text { Number of } \\
\text { obs. }\end{array}$ & $\begin{array}{c}\text { Fraction of } \\
\text { violations }\end{array}$ & $\begin{array}{c}\text { Initial } \\
\text { Tightness }\end{array}$ & $\begin{array}{c}\text { Number of } \\
\text { obs. }\end{array}$ & $\begin{array}{c}\text { Fraction of } \\
\text { violations }\end{array}$ \\
\hline Current ratio & 1.44 & 808 & 0.09 & 1.09 & 5,428 & 0.15 \\
\hline Net worth & 0.58 & 3,727 & 0.05 & 0.68 & 13,021 & 0.14 \\
\hline Tangible net worth & 0.65 & 2,138 & 0.04 & 0.68 & 13,021 & 0.14 \\
\hline Debt-to-EBITDA & 0.83 & 6,587 & 0.19 & - & - & - \\
\hline All covenants & 0.53 & 9,721 & 0.16 & - & - & - \\
\hline
\end{tabular}




\section{Table IA.4: Covenant Data - Annual Frequency}

This table presents the fraction of covenant violations and number of violations based on the current ratio, net worth, tangible net worth, and debt-toEBITDA. Current ratio is current assets over current liabilities. Net worth is assets minus total liabilities. Tangible net worth is tangible assets minus total liabilities. Debt-to-EBITDA is total debt over earnings before interest, taxes, depreciation, and amortization. Covenant violation is a dummy variable that takes a value of one if the firm violates a covenant (at least one out of four covenants in the case of all covenants) during the year in at least one quarter. The sample consists of annual observations on Investor Responsibility Research Center (IRRC) non-financial firms from 1994 to 2008 for which syndicated loans data are available from DealScan. The sample includes only those observations in which the absolute value of the relative binding distance to the covenant threshold is less than the bandwidth $(h)$.

\begin{tabular}{|c|c|c|c|c|c|c|c|c|}
\hline & \multicolumn{2}{|c|}{ Bandwidth $h=0.2$} & \multicolumn{2}{|c|}{ Bandwidth $h=0.3$} & \multicolumn{2}{|c|}{ Bandwidth $h=0.4$} & \multicolumn{2}{|c|}{ Full sample } \\
\hline & $\begin{array}{c}\text { Fraction } \\
\text { of viol. }\end{array}$ & $\begin{array}{l}\text { Number } \\
\text { of viol. }\end{array}$ & $\begin{array}{c}\text { Fraction } \\
\text { of viol. }\end{array}$ & $\begin{array}{l}\text { Number } \\
\text { of viol. }\end{array}$ & $\begin{array}{c}\text { Fraction } \\
\text { of viol. }\end{array}$ & $\begin{array}{l}\text { Number } \\
\text { of viol. }\end{array}$ & $\begin{array}{c}\text { Fraction } \\
\text { of viol. }\end{array}$ & $\begin{array}{l}\text { Number } \\
\text { of viol. }\end{array}$ \\
\hline Current ratio & 0.28 & 5 & 0.30 & 14 & 0.27 & 22 & 0.14 & 33 \\
\hline Net worth & 0.16 & 9 & 0.11 & 19 & 0.10 & 30 & 0.07 & 81 \\
\hline Tangible net worth & 0.24 & 7 & 0.15 & 10 & 0.10 & 14 & 0.06 & 39 \\
\hline Debt-to-EBITDA & 0.57 & 30 & 0.41 & 88 & 0.34 & 147 & 0.30 & 570 \\
\hline All covenants & 0.46 & 50 & 0.37 & 129 & 0.32 & 211 & 0.24 & 675 \\
\hline
\end{tabular}




\section{Table IA.5: Averages for Violation and Non-Violation Groups - Sam- ple outside Bandwidth}

This table presents sample averages of board composition and firm characteristics for observations with no covenant violation and observations with at least one covenant violation. A covenant violation occurs if the firm violates at least one out of four covenants (current ratio, net worth, tangible net worth, and debt-to-EBITDA) during the year in at least one quarter. The sample consists of annual observations on Investor Responsibility Research Center (IRRC) non-financial firms from 1994 to 2008 for which syndicated loans data are available from DealScan. The sample includes observations outside the bandwidth $(h=0.4)$.

\begin{tabular}{lcccc}
\hline & No violation & Violation & Difference \\
$(1)$ & $(2)$ & -statistic \\
& 6.41 & 6.36 & 0.05 & 0.44 \\
\hline Number of independent directors (2 leads) & 5.95 & 5.94 & 0.01 & 0.12 \\
Number of independent directors (2 lags) & 5.97 & 5.98 & -0.01 & -0.10 \\
Number of independent directors (1 lag) & 6.02 & 6.03 & -0.01 & -0.08 \\
Number of independent directors & 2.74 & 2.54 & 0.20 & 2.47 \\
Number of non-independent directors (2 leads) & 3.23 & 3.00 & 0.23 & 2.35 \\
Number of non-independent directors (2 lags) & 3.19 & 2.94 & 0.24 & 2.61 \\
Number of non-independent directors (1 lag) & 3.13 & 2.89 & 0.23 & 2.54 \\
Number of non-independent directors & & & & \\
& 3,403 & 5,234 & $-1,831$ & -1.93 \\
Firm size (\$ millions) & 0.20 & 0.34 & -0.13 & -15.67 \\
Leverage & 22.34 & 22.23 & 0.11 & 0.12 \\
Firm age & 2.75 & 3.17 & -0.42 & -4.28 \\
Number of segments & 2.14 & 1.51 & 0.62 & 13.38 \\
Market-to-book & 0.02 & 0.02 & 0.00 & -1.34 \\
R\&D & 0.37 & 0.45 & -0.09 & -7.18 \\
Stock return volatility & 0.11 & 0.05 & 0.05 & 11.29 \\
Free cash flow & 0.17 & 0.10 & 0.07 & 16.77 \\
Return on assets & 9.27 & 9.39 & -0.11 & -0.84 \\
Governance index & 0.02 & 0.02 & 0.00 & 1.67 \\
CEO ownership & 7.64 & 6.40 & 1.24 & 3.37 \\
CEO tenure & & & & \\
Number of observations & 1,672 & 464 & & \\
Number of firms & 495 & 241 & & \\
Fraction of observations in violation & & 0.22 & & \\
Fraction of firms in violation & & 0.44 & & \\
\hline
\end{tabular}




\section{Table IA.6: Summary Statistics for Violation and Non-Violation Groups}

This table presents mean, standard deviation, minimum, 10th percentile, median, 90th percentile, maximum, number of observations, and number of firms for each variable. Covenant violation is a dummy variable that takes a value of one if the firm violates at least one out of four covenants (current ratio, net worth, tangible net worth, and debt-to-EBITDA) during the year in at least one quarter. The sample consists of annual observations on Investor Responsibility Research Center (IRRC) non-financial firms from 1994 to 2008 for which syndicated loans data are available from DealScan. The sample in Panel A includes observations in which the absolute value of the relative binding distance to the covenant threshold is less than the bandwidth $(h=0.4)$. The sample in Panel B includes observations outside the bandwidth.

Panel A: Sample within Bandwidth $h=0.4$

\begin{tabular}{|c|c|c|c|c|c|c|c|c|c|}
\hline & Mean & $\begin{array}{l}\text { Standard } \\
\text { deviation }\end{array}$ & Minimum & $\begin{array}{l}\text { 10th } \\
\text { pctile }\end{array}$ & Median & $\begin{array}{c}\text { 90th } \\
\text { pctile }\end{array}$ & Maximum & $\begin{array}{l}\text { Number } \\
\text { of obs. }\end{array}$ & $\begin{array}{l}\text { Number } \\
\text { of firms }\end{array}$ \\
\hline Number of non-independent directors & 2.95 & 1.84 & 1.00 & 1.00 & 2.00 & 6.00 & 10.00 & 665 & 222 \\
\hline Number of directors & 9.31 & 2.11 & 5.00 & 7.00 & 9.00 & 12.00 & 19.00 & 665 & 222 \\
\hline Firm size ( $\$$ millions $)$ & 2,711 & 4,374 & 73 & 346 & 1,269 & 6,153 & 35,525 & 665 & 222 \\
\hline Leverage & 0.31 & 0.15 & 0.00 & 0.09 & 0.33 & 0.49 & 0.74 & 665 & 222 \\
\hline Market-to-book & 1.47 & 0.57 & 0.70 & 0.96 & 1.37 & 2.10 & 6.24 & 665 & 222 \\
\hline $\mathrm{R} \& \mathrm{D}$ & 0.02 & 0.03 & 0.00 & 0.00 & 0.00 & 0.04 & 0.24 & 665 & 222 \\
\hline Stock return volatility & 0.37 & 0.18 & 0.12 & 0.19 & 0.33 & 0.59 & 1.67 & 665 & 222 \\
\hline Free cash flow & 0.07 & 0.05 & -0.22 & 0.01 & 0.08 & 0.13 & 0.26 & 665 & 222 \\
\hline Return on assets & 0.13 & 0.06 & -0.17 & 0.07 & 0.12 & 0.20 & 0.41 & 665 & 222 \\
\hline Governance index & 9.42 & 2.66 & 3.00 & 6.00 & 9.00 & 13.00 & 15.00 & 665 & 222 \\
\hline
\end{tabular}


Panel B: Sample outside Bandwidth $h=0.4$

\begin{tabular}{|c|c|c|c|c|c|c|c|c|c|}
\hline & Mean & $\begin{array}{l}\text { Standard } \\
\text { deviation }\end{array}$ & Minimum & $\begin{array}{c}\text { 10th } \\
\text { pctile }\end{array}$ & Median & $\begin{array}{c}\text { 90th } \\
\text { pctile }\end{array}$ & Maximum & $\begin{array}{l}\text { Number } \\
\text { of obs. }\end{array}$ & $\begin{array}{l}\text { Number } \\
\text { of firms }\end{array}$ \\
\hline Number of independent directors & 6.40 & 2.05 & 1.00 & 4.00 & 6.00 & 9.00 & 15.00 & 2,136 & 546 \\
\hline Number of non-independent directors & 2.70 & 1.58 & 1.00 & 1.00 & 2.00 & 5.00 & 13.00 & 2,136 & 546 \\
\hline Ratio of indep. to non-indep. directors & 3.47 & 2.54 & 0.17 & 1.00 & 2.58 & 8.00 & 13.00 & 2,136 & 546 \\
\hline Number of directors & 9.10 & 2.13 & 4.00 & 6.00 & 9.00 & 12.00 & 17.00 & 2,136 & 546 \\
\hline Firm size & 3,801 & 12,725 & 43 & 374 & 1,226 & 7,605 & 270,634 & 2,136 & 546 \\
\hline Leverage & 0.23 & 0.16 & 0.00 & 0.01 & 0.23 & 0.43 & 0.87 & 2,136 & 546 \\
\hline Firm age & 22.31 & 17.40 & 1.00 & 6.00 & 17.00 & 42.00 & 81.00 & 2,136 & 546 \\
\hline Number of segments & 2.84 & 1.85 & 1.00 & 1.00 & 3.00 & 5.00 & 10.00 & 2,136 & 546 \\
\hline Market-to-book & 2.00 & 1.25 & 0.62 & 1.07 & 1.64 & 3.31 & 8.89 & 2,136 & 546 \\
\hline $\mathrm{R} \& \mathrm{D}$ & 0.02 & 0.04 & 0.00 & 0.00 & 0.00 & 0.07 & 0.37 & 2,136 & 546 \\
\hline Stock return volatility & 0.39 & 0.21 & 0.12 & 0.19 & 0.34 & 0.65 & 1.74 & 2,136 & 546 \\
\hline Free cash flow & 0.10 & 0.09 & -0.79 & 0.01 & 0.09 & 0.19 & 0.36 & 2,136 & 546 \\
\hline Return on assets & 0.16 & 0.09 & -0.66 & 0.07 & 0.15 & 0.26 & 0.44 & 2,136 & 546 \\
\hline Governance index & 9.30 & 2.63 & 3.00 & 6.00 & 9.00 & 13.00 & 17.00 & 2,136 & 546 \\
\hline CEO ownership & 0.02 & 0.05 & 0.00 & 0.00 & 0.00 & 0.05 & 0.30 & 2,136 & 546 \\
\hline CEO tenure & 7.37 & 7.38 & 0.00 & 1.00 & 5.00 & 17.00 & 48.00 & 2,136 & 546 \\
\hline Covenant violation & 0.22 & 0.41 & 0.00 & 0.00 & 0.00 & 1.00 & 1.00 & 2,136 & 546 \\
\hline Binding distance & 0.07 & 1.66 & -7.36 & -1.17 & 0.43 & 0.99 & 4.14 & 2,136 & 546 \\
\hline
\end{tabular}




\section{Table IA.7: Regression of Number of Independent Directors}

This table presents estimates of firm fixed effects, first differences and ordinary least squares (OLS) panel regressions of the logarithm of the number of independent directors. Covenant violation is a dummy variable that takes a value of one if the firm violates at least one out of four covenants (current ratio, net worth, tangible net worth, and debt-to-EBITDA) during the year in at least one quarter. The firm-level control variables are firm size (log), leverage, firm age (log), number of segments (log), market-to-book $(\log ), \mathrm{R} \& \mathrm{D}$, stock return volatility, free cash flow, return on assets, governance index, CEO ownership, and CEO tenure. All explanatory variables are lagged two years. The sample consists of annual observations on Investor Responsibility Research Center (IRRC) non-financial firms from 1994 to 2008 for which syndicated loans data are available from DealScan. The sample includes only those observations in which the absolute value of the relative binding distance to the covenant threshold is less than the bandwidth $(h=0.4)$. Refer to Table A1 in the Appendix for variable definitions. Robust $t$-statistics adjusted for firm-level clustering are in parentheses. ${ }^{*}, * *, * * *$ indicates significance at the $10 \%, 5 \%$, and $1 \%$ levels.

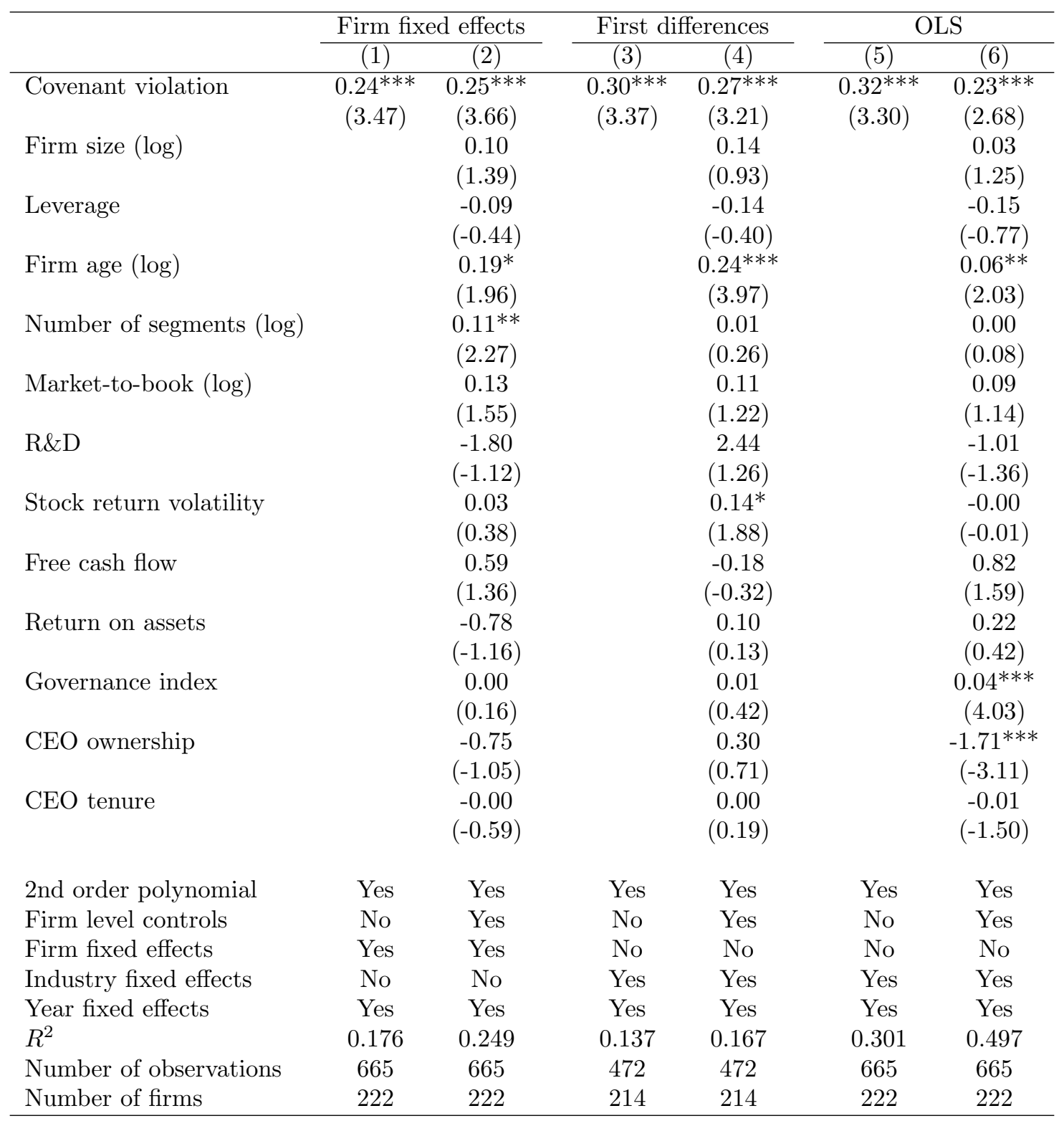




\section{Table IA.8: Regression of Firm Characteristics}

This table presents estimates of firm fixed effects panel regressions of firm size (log), leverage, firm age (log), number of segments $(\log )$, market-to-book $(\log ), \mathrm{R} \& \mathrm{D}$, stock return volatility, free cash flow, return on assets, governance index, CEO ownership, CEO tenure, and investment. Covenant violation is a dummy variable that takes a value of one if the firm violates at least one out of four covenants (current ratio, net worth, tangible net worth, and debt-to-EBITDA) during the year in at least one quarter. All explanatory variables are contemporaneous. The sample consists of annual observations on Investor Responsibility Research Center (IRRC) non-financial firms from 1994 to 2008 for which syndicated loans data are available from DealScan. The sample includes only those observations in which the absolute value of the relative binding distance to the covenant threshold is less than the bandwidth $(h=0.4)$. Refer to Table A1 in the Appendix for variable definitions. Robust $t$-statistics adjusted for firm-level clustering are in parentheses. ${ }^{*}, * *, * * *$ indicates significance at the $10 \%, 5 \%$, and $1 \%$ levels.

\begin{tabular}{lcc}
\hline & \multicolumn{2}{c}{ Covenant violation } \\
\cline { 2 - 3 } & Coefficient & $t$-statistic \\
\hline Firm size $(\log )$ & -0.0031 & -0.19 \\
Leverage & -0.0033 & -0.05 \\
Firm age $(\log )$ & 0.0030 & 0.13 \\
Number of segments $(\log )$ & -0.0792 & -0.83 \\
Market-to-book $(\log )$ & 0.0273 & 0.70 \\
R\&D & 0.0020 & 0.76 \\
Stock return volatility & 0.0353 & 1.09 \\
Free cash flow & 0.0026 & 0.25 \\
Return on assets & 0.0006 & 0.06 \\
Governance index & -0.0082 & -0.06 \\
CEO ownership & 0.0052 & 0.85 \\
CEO tenure & -0.1890 & -0.19 \\
Investment & -0.0020 & -0.38 \\
& & \\
2nd order polynomial & Yes & \\
Firm fixed effects & Yes & \\
Year fixed effects & Yes & \\
Number of observations & 665 & \\
Number of firms & 222 & \\
\hline
\end{tabular}




\section{Table IA.9: Regression of Number of Independent Directors - Placebo Test using SEC- DealScan Matched Sample}

This table presents estimates of firm fixed effects panel regressions of the logarithm of the number of independent directors. Covenant violation is a dummy variable that takes a value of one if the firm violates at least one out of four covenants (current ratio, net worth, tangible net worth, and debt-to-EBITDA) during the year in at least one quarter. All explanatory variables are lagged two years. The estimates are shown using different distances to the real threshold, which is set at zero. The sample consists of annual observations on Investor Responsibility Research Center (IRRC) non-financial firms from 1994 to 2008 for which syndicated loans data are available from DealScan. The sample drops observations in case the covenant violation dummy is zero but there is a covenant violation according to the SEC's 10-Q or 10-K filings. The sample includes only those observations in which the absolute value of the relative binding distance to the covenant threshold is less than the bandwidth $(h)$. Refer to Table A1 in the Appendix for variable definitions. Robust $t$-statistics adjusted for firm-level clustering are in parentheses. *, **, *** indicates significance at the $10 \%, 5 \%$, and $1 \%$ levels.

\begin{tabular}{lccccccccc}
\hline & \multicolumn{10}{c}{ Distance to real threshold } \\
\cline { 2 - 10 } & -0.4 & -0.3 & -0.2 & -0.1 & 0.0 & 0.1 & 0.2 & 0.3 & 0.4 \\
& $(1)$ & $(2)$ & $(3)$ & $(4)$ & $(5)$ & $(6)$ & $(7)$ & $(8)$ & $(9)$ \\
\hline Covenant violation & 0.19 & 0.02 & 0.11 & 0.03 & $0.24^{* * *}$ & -0.04 & 0.01 & -0.04 & -0.01 \\
& $(1.00)$ & $(0.19)$ & $(0.80)$ & $(0.35)$ & $(3.35)$ & $(-0.87)$ & $(0.15)$ & $(-0.97)$ & $(-0.37)$ \\
Marginal effects (at mean) & 1.21 & 0.13 & 0.70 & 0.19 & 1.53 & -0.26 & 0.06 & -0.26 & -0.06 \\
& & & & & & & & & \\
2nd order polynomial & Yes & Yes & Yes & Yes & Yes & Yes & Yes & Yes & Yes \\
Firm fixed effects & Yes & Yes & Yes & Yes & Yes & Yes & Yes & Yes & Yes \\
Year fixed effects & Yes & Yes & Yes & Yes & Yes & Yes & Yes & Yes & Yes \\
$R^{2}$ & 0.209 & 0.220 & 0.205 & 0.150 & 0.174 & 0.177 & 0.202 & 0.185 & 0.197 \\
Number of observations & 94 & 139 & 220 & 381 & 590 & 778 & 958 & 983 & 1,008 \\
Number of firms & 41 & 59 & 87 & 142 & 203 & 248 & 292 & 291 & 295 \\
\hline
\end{tabular}




\section{Table IA.10: Summary Statistics - SEC Sample}

This table presents mean, standard deviation, minimum, 10th percentile, median, 90th percentile, maximum, number of observations, and number of firms for each variable. The sample consists of annual observations on Investor Responsibility Research Center (IRRC) firms from 1994 to 2008 . Financial industries are omitted (SIC codes 6000-6999). Covenant violation is a dummy variable that takes a value of one if the firm reports a covenant violation in SEC's 10-Q or 10-K filings. Refer to Table A1 in the Appendix for variable definitions. Financial ratios are winsorized at the bottom and top 1\% level.

\begin{tabular}{|c|c|c|c|c|c|c|c|c|c|}
\hline & Mean & $\begin{array}{l}\text { Standard } \\
\text { deviation }\end{array}$ & Minimum & $\begin{array}{l}\text { 10th } \\
\text { pctile }\end{array}$ & Median & $\begin{array}{c}90 \text { th } \\
\text { pctile }\end{array}$ & Maximum & $\begin{array}{l}\text { Number } \\
\text { of obs. }\end{array}$ & $\begin{array}{l}\text { Number } \\
\text { of firms }\end{array}$ \\
\hline Number of non-independent directors & 2.91 & 1.75 & 1.00 & 1.00 & 3.00 & 5.00 & 13.00 & 8,514 & 1,296 \\
\hline Number of directors & 9.54 & 2.37 & 4.00 & 7.00 & 9.00 & 13.00 & 28.00 & 8,514 & 1,296 \\
\hline Firm size ( $\$$ millions $)$ & 5,340 & 15,336 & 38 & 336 & 1,624 & 13,779 & 697,239 & 8,514 & 1,296 \\
\hline Leverage & 0.24 & 0.16 & 0.00 & 0.01 & 0.24 & 0.43 & 0.89 & 8,514 & 1,296 \\
\hline Market-to-book & 2.01 & 1.45 & 0.53 & 1.07 & 1.56 & 3.38 & 27.09 & 8,514 & 1,296 \\
\hline $\mathrm{R} \& \mathrm{D}$ & 0.03 & 0.05 & 0.00 & 0.00 & 0.00 & 0.10 & 0.66 & 8,514 & 1,296 \\
\hline Stock return volatility & 0.36 & 0.20 & 0.11 & 0.16 & 0.31 & 0.60 & 2.24 & 8,514 & 1,296 \\
\hline Free cash flow & 0.09 & 0.09 & -0.92 & 0.00 & 0.09 & 0.18 & 0.36 & 8,514 & 1,296 \\
\hline Return on assets & 0.15 & 0.08 & -0.67 & 0.07 & 0.14 & 0.25 & 0.43 & 8,514 & 1,296 \\
\hline Governance index & 9.37 & 2.63 & 2.00 & 6.00 & 9.00 & 13.00 & 17.00 & 8,514 & 1,296 \\
\hline
\end{tabular}




\section{Table IA.11: Regression of Number of Independent Directors - SEC Sample}

This table presents estimates of firm fixed effects panel regressions of the logarithm of the number of independent directors. Covenant violation is a dummy variable that takes a value of one if the firm reports a covenant violation in SEC's 10-Q or 10-K filings. Regressions include third-order polynomials and quintile indicator variables for leverage, return on assets, interest expense-to-assets ratio, net worth-to-assets ratio, and cash-toassets ratio. The firm-level control variables are firm size (log), leverage, firm age (log), number of segments $(\log )$, market-to-book $(\log ), \mathrm{R} \& \mathrm{D}$, stock return volatility, free cash flow, return on assets, governance index, CEO ownership, and CEO tenure. All explanatory variables are lagged two years. The sample consists of annual observations on Investor Responsibility Research Center (IRRC) non-financial firms from 1994 to 2008. Refer to Table A1 in the Appendix for variable definitions. Robust $t$-statistics adjusted for firm-level clustering are in parentheses. $*, * *, * * *$ indicates significance at the $10 \%, 5 \%$, and $1 \%$ levels.

\begin{tabular}{|c|c|c|c|c|c|c|}
\hline & \multicolumn{2}{|c|}{ All violations } & \multicolumn{2}{|c|}{ First violations } & \multicolumn{2}{|c|}{ New violations } \\
\hline & $(1)$ & $(2)$ & $(3)$ & $(4)$ & $(5)$ & (6) \\
\hline \multirow[t]{2}{*}{ Covenant violation - SEC } & $0.04^{* *}$ & $0.04^{* *}$ & $0.04^{*}$ & $0.04^{*}$ & $0.03^{*}$ & $0.03^{*}$ \\
\hline & $(2.34)$ & $(2.53)$ & $(1.81)$ & $(1.93)$ & $(1.77)$ & $(1.77)$ \\
\hline Marginal effects (at mean) & 0.27 & 0.27 & 0.27 & 0.27 & 0.20 & 0.20 \\
\hline Polyn. and covenant quintile indicators & Yes & Yes & Yes & Yes & Yes & Yes \\
\hline Firm level controls & No & Yes & No & Yes & No & Yes \\
\hline Firm fixed effects & Yes & Yes & Yes & Yes & Yes & Yes \\
\hline Year fixed effects & Yes & Yes & Yes & Yes & Yes & Yes \\
\hline$R^{2}$ & 0.173 & 0.198 & 0.169 & 0.194 & 0.172 & 0.198 \\
\hline Number of observations & 8,514 & 8,514 & 7,741 & 7,741 & 8,337 & 8,337 \\
\hline Number of firms & 1,296 & 1,296 & 1,223 & 1,223 & 1,294 & 1,294 \\
\hline
\end{tabular}




\section{Table IA.12: Regression of Number of Independent Directors - Robustness}

This table presents estimates of firm fixed effects (columns (2)-(8)) panel regressions of the logarithm of the number of independent directors. Covenant violation is a dummy variable that takes a value of one if the firm violates at least one out of four covenants (current ratio, net worth, tangible net worth, and debt-to-EBITDA) during the year in at least one quarter. All explanatory variables are lagged two years. Column (1) presents estimates of a Poisson regression. Column (2) presents estimates of a regression excluding observations in the year in which the CEO is replaced as well as the two years after the CEO turnover. Column (3) presents estimates of a regression in which debt-to-EBITDA covenants are excluded from the definition of covenant violations. Column (4) presents estimates of a regression in which interest coverage covenants are included in the definition of covenant violations. In columns (5) and (6) the sample period is the pre-SOX period (1994-2002) and post-SOX period (2003-2008) respectively. In column (7) the sample period is extended to 1994-2014. Column (8) presents estimates of a regression in which the dependent variable is the logarithm of the ratio of the number of independent directors to board size. The sample consists of annual observations on Investor Responsibility Research Center (IRRC) non-financial firms from 1994 to 2008 for which syndicated loans data are available from DealScan. The sample includes only those observations in which the absolute value of the relative binding distance to the covenant threshold is less than the bandwidth $(h=0.4)$. Refer to Table A1 in the Appendix for variable definitions. Robust $t$-statistics adjusted for firm-level clustering are in parentheses. ${ }^{*}, * *, * *$ indicates significance at the $10 \%, 5 \%$, and $1 \%$ levels.

\begin{tabular}{|c|c|c|c|c|c|c|c|c|}
\hline & $\begin{array}{c}\text { Poisson } \\
\text { regression } \\
(1)\end{array}$ & $\begin{array}{c}\text { Excluding } \\
\text { CEO } \\
\text { turnover } \\
(2)\end{array}$ & $\begin{array}{c}\text { Excluding } \\
\text { Debt-to- } \\
\text { EBITDA } \\
(3)\end{array}$ & $\begin{array}{c}\text { Including } \\
\text { interest } \\
\text { coverage } \\
(4)\end{array}$ & $\begin{array}{c}\text { Pre-SOX } \\
(5)\end{array}$ & $\begin{array}{c}\text { Post-SOX } \\
(6)\end{array}$ & $\begin{array}{c}\text { Sample } \\
1994-2014 \\
(7)\end{array}$ & $\begin{array}{c}\text { Board inde- } \\
\text { pendence } \\
(8)\end{array}$ \\
\hline Covenant violation & $\begin{array}{c}0.19^{* * *} \\
(3.57)\end{array}$ & $\begin{array}{c}0.30^{* * *} \\
(2.62)\end{array}$ & $\begin{array}{l}0.18^{*} \\
(1.75)\end{array}$ & $\begin{array}{c}0.20^{* * *} \\
(2.92)\end{array}$ & $\begin{array}{l}0.20^{* *} \\
(2.25)\end{array}$ & $\begin{array}{l}0.21^{* *} \\
(2.17)\end{array}$ & $\begin{array}{c}0.17^{* * *} \\
(3.57)\end{array}$ & $\begin{array}{c}0.16^{* * *} \\
(2.97)\end{array}$ \\
\hline Marginal effects (at mean) & 1.21 & 1.92 & 1.15 & 1.30 & 1.28 & 1.34 & 1.15 & 0.11 \\
\hline 2nd order polynomial & Yes & Yes & Yes & Yes & Yes & Yes & Yes & Yes \\
\hline Firm fixed effects & Yes & Yes & Yes & Yes & Yes & Yes & Yes & Yes \\
\hline Year fixed effects & Yes & Yes & Yes & Yes & Yes & Yes & Yes & Yes \\
\hline$R^{2}$ & & 0.233 & 0.199 & 0.192 & 0.091 & 0.221 & 0.232 & 0.215 \\
\hline Number of observations & 665 & 360 & 402 & 655 & 294 & 291 & 1,008 & 665 \\
\hline Number of firms & 222 & 132 & 143 & 217 & 108 & 112 & 300 & 222 \\
\hline
\end{tabular}




\section{Table IA.13: Regression of Number of Independent Directors - Ex- cluding CEO Turnover}

This table presents estimates of firm fixed effects panel regressions of the logarithm of the number of independent directors. Covenant violation is a dummy variable that takes a value of one if the firm violates at least one out of four covenants (current ratio, net worth, tangible net worth, and debt-to-EBITDA) during the year in at least one quarter. The firm-level control variables are firm size (log), leverage, firm age (log), number of segments (log), market-to-book $(\log ), \mathrm{R} \& \mathrm{D}$, stock return volatility, free cash flow, return on assets, governance index, CEO ownership, and CEO tenure. All explanatory variables are lagged two years. Columns (1) and (2) present estimates of regressions excluding observations in the two years after the CEO is replaced. Columns (3) and (4) present estimates of regressions excluding observations in the year in which the CEO is replaced and a violation occurred as well as the two years after the CEO turnover. Columns (5) and (6) present estimates of regressions excluding observations in the two years after the CEO is replaced and a violation occurred. The sample consists of annual observations on Investor Responsibility Research Center (IRRC) non-financial firms from 1994 to 2008 for which syndicated loans data are available from DealScan. The sample includes only those observations in which the absolute value of the relative binding distance to the covenant threshold is less than the bandwidth $(h=0.4)$. Refer to Table A1 in the Appendix for variable definitions. Robust $t$-statistics adjusted for firm-level clustering are in parentheses. *, **, *** indicates significance at the $10 \%, 5 \%$, and $1 \%$ levels.

\begin{tabular}{lcccccc}
\hline & $(1)$ & $(2)$ & $(3)$ & $(4)$ & $(5)$ & $(6)$ \\
\hline Covenant violation & $0.28^{* *}$ & $0.30^{* * *}$ & $0.24^{* * *}$ & $0.25^{* * *}$ & $0.24^{* * *}$ & $0.26^{* * *}$ \\
& $(2.49)$ & $(2.80)$ & $(2.87)$ & $(3.27)$ & $(2.83)$ & $(3.08)$ \\
Marginal effects (at mean) & 1.60 & 1.92 & 1.53 & 1.60 & 1.53 & 1.66 \\
& & & & & & \\
2nd order polynomial & Yes & Yes & Yes & Yes & Yes & Yes \\
Firm level controls & No & Yes & No & Yes & No & Yes \\
Firm fixed effects & Yes & Yes & Yes & Yes & Yes & Yes \\
Industry fixed effects & No & No & No & No & No & No \\
Year fixed effects & Yes & Yes & Yes & Yes & Yes & Yes \\
$R^{2}$ & 0.248 & 0.346 & 0.216 & 0.292 & 0.199 & 0.270 \\
Number of observations & 411 & 411 & 541 & 541 & 576 & 576 \\
Number of firms & 150 & 150 & 185 & 185 & 195 & 195 \\
\hline
\end{tabular}




\section{Table IA.14: Regression of Number of Independent Directors - In- cluding Interest Coverage Covenant}

This table presents estimates of firm fixed effects, first differences and ordinary least squares (OLS) panel regressions of the logarithm of the number of independent directors. Covenant violation is a dummy variable that takes a value of one if the firm violates at least one out of five covenants (current ratio, net worth, tangible net worth, debt-to-EBITDA, interest coverage) during the year in at least one quarter. The firm-level control variables are firm size (log), leverage, firm age (log), number of segments (log), market-to-book $(\log ), \mathrm{R} \& \mathrm{D}$, stock return volatility, free cash flow, return on assets, governance index, CEO ownership, and CEO tenure. All explanatory variables are lagged two years. Panel A presents estimates using all covenant violations, and Panel B presents estimates using the first covenant violation or new violations for each firm. The sample consists of annual observations on Investor Responsibility Research Center (IRRC) non-financial firms from 1994 to 2008 for which syndicated loans data are available from DealScan. The sample includes only those observations in which the absolute value of the relative binding distance to the covenant threshold is less than the bandwidth $(h=0.4)$. Refer to Table A1 in the Appendix for variable definitions. Robust $t$-statistics adjusted for firm-level clustering are in parentheses. $*, * *, * * *$ indicates significance at the $10 \%, 5 \%$, and $1 \%$ levels.

\begin{tabular}{|c|c|c|c|c|c|c|}
\hline & \multicolumn{2}{|c|}{ Firm fixed effects } & \multicolumn{2}{|c|}{ First differences } & \multicolumn{2}{|c|}{ OLS } \\
\hline & (1) & $(2)$ & $(3)$ & $(4)$ & $(5)$ & $(6)$ \\
\hline Covenant violation & $\begin{array}{c}0.20^{* * *} \\
(2.92)\end{array}$ & $\begin{array}{c}0.21^{* * *} \\
(3.05)\end{array}$ & $\begin{array}{c}0.30^{* * * *} \\
(3.50)\end{array}$ & $\begin{array}{c}0.28^{* * *} \\
(3.53)\end{array}$ & $\begin{array}{c}0.24^{* *} \\
(2.53)\end{array}$ & $\begin{array}{c}0.18^{* *} \\
(2.06)\end{array}$ \\
\hline Marginal effects (at mean) & 1.30 & 1.36 & 1.95 & 1.82 & 1.56 & 1.17 \\
\hline 2nd order polynomial & Yes & Yes & Yes & Yes & Yes & Yes \\
\hline Firm level controls & No & Yes & No & Yes & No & Yes \\
\hline Firm fixed effects & Yes & Yes & No & No & No & No \\
\hline Industry fixed effects & No & No & Yes & Yes & Yes & Yes \\
\hline Year fixed effects & Yes & Yes & Yes & Yes & Yes & Yes \\
\hline$R^{2}$ & 0.192 & 0.253 & 0.146 & 0.181 & 0.303 & 0.503 \\
\hline Number of observations & 655 & 655 & 469 & 469 & 655 & 655 \\
\hline Number of firms & 217 & 217 & 217 & 217 & 211 & 211 \\
\hline
\end{tabular}

Panel B: First and New Violations

\begin{tabular}{lcccccccc}
\hline & \multicolumn{3}{c}{ First violations } & & \multicolumn{3}{c}{ New violations } \\
\cline { 2 - 3 } & Firm FE & First diff. & OLS & & Firm FE & First diff. & OLS \\
& $(1)$ & $(2)$ & $(3)$ & & $(4)$ & $(5)$ & $(6)$ \\
\hline Covenant violation & $0.30^{* * *}$ & $0.36^{* * *}$ & $0.26^{* *}$ & & $0.18^{* *}$ & $0.32^{* * *}$ & $0.31^{* *}$ \\
& $(3.18)$ & $(3.13)$ & $(2.26)$ & & $(2.15)$ & $(3.10)$ & $(2.46)$ \\
Marginal effects (at means) & 1.95 & 2.33 & 1.69 & & 1.17 & 2.08 & 2.01 \\
& & & & & & & \\
2nd order polynomial & Yes & Yes & Yes & & Yes & Yes & Yes \\
Firm level controls & No & No & No & & No & No & No \\
Firm fixed effects & Yes & No & No & & Yes & No & No \\
Industry fixed effects & No & Yes & Yes & & No & Yes & Yes \\
Year fixed effects & Yes & Yes & Yes & & Yes & Yes & Yes \\
$R^{2}$ & 0.158 & 0.175 & 0.386 & & 0.209 & 0.204 & 0.332 \\
Number of observations & 514 & 347 & 514 & & 482 & 349 & 482 \\
Number of firms & 188 & 181 & 188 & & 166 & 158 & 166 \\
\hline
\end{tabular}




\section{Table IA.15: Regression of Number of Independent Directors - Sam- ple Period 1994-2014}

This table presents estimates of firm fixed effects, first differences and ordinary least squares (OLS) panel regressions of the logarithm of the number of independent directors. Covenant violation is a dummy variable that takes a value of one if the firm violates at least one out of four covenants (current ratio, net worth, tangible net worth, and debt-to-EBITDA) during the year in at least one quarter. The firm-level control variables are firm size (log), leverage, firm age (log), number of segments (log), market-to-book (log), R\&D, stock return volatility, free cash flow, return on assets, governance index, CEO ownership, and CEO tenure. All explanatory variables are lagged two years. Panel A presents estimates using all covenant violations, and Panel B presents estimates using the first covenant violation or new violations for each firm. The sample consists of annual observations on Investor Responsibility Research Center (IRRC) non-financial firms from 1994 to 2014 for which syndicated loans data are available from DealScan. The sample includes only those observations in which the absolute value of the relative binding distance to the covenant threshold is less than the bandwidth $(h=0.4)$. Refer to Table A1 in the Appendix for variable definitions. Robust $t$-statistics adjusted for firm-level clustering are in parentheses. ${ }^{*}, * * * * *$ indicates significance at the $10 \%, 5 \%$, and $1 \%$ levels.

\begin{tabular}{|c|c|c|c|c|c|c|}
\hline & \multicolumn{2}{|c|}{ Firm fixed effects } & \multicolumn{2}{|c|}{ First differences } & \multicolumn{2}{|c|}{ OLS } \\
\hline & (1) & $(2)$ & $(3)$ & $(4)$ & $(5)$ & (6) \\
\hline Covenant violation & $\begin{array}{c}0.17^{* * *} \\
(3.57)\end{array}$ & $\begin{array}{c}0.16^{* * *} \\
(3.54)\end{array}$ & $\begin{array}{c}0.14^{* *} \\
(2.47)\end{array}$ & $\begin{array}{c}0.13^{* *} \\
(2.42)\end{array}$ & $\begin{array}{c}0.20^{* * *} \\
(2.95)\end{array}$ & $\begin{array}{c}0.14^{* *} \\
(2.46)\end{array}$ \\
\hline Marginal effects (at mean) & 1.15 & 1.08 & 0.95 & 0.88 & 1.36 & 0.95 \\
\hline 2nd order polynomial & Yes & Yes & Yes & Yes & Yes & Yes \\
\hline Firm level controls & No & Yes & No & Yes & No & Yes \\
\hline Firm fixed effects & Yes & Yes & No & No & No & No \\
\hline Industry fixed effects & No & No & Yes & Yes & Yes & Yes \\
\hline Year fixed effects & Yes & Yes & Yes & Yes & Yes & Yes \\
\hline$R^{2}$ & 0.232 & 0.275 & 0.110 & 0.138 & 0.290 & 0.483 \\
\hline Number of observations & 1,008 & 1,008 & 740 & 740 & 1,008 & 1,008 \\
\hline Number of firms & 300 & 300 & 286 & 286 & 300 & 300 \\
\hline
\end{tabular}

Panel B: First and New Violations

\begin{tabular}{lcccccccc}
\hline & \multicolumn{3}{c}{ First violations } & & \multicolumn{3}{c}{ New violations } \\
\cline { 2 - 3 } & Firm FE & First diff. & OLS & & Firm FE & First diff. & OLS \\
& $(1)$ & $(2)$ & $(3)$ & & $(4)$ & $(5)$ & $(6)$ \\
\hline Covenant violation & $0.25^{* * *}$ & $0.22^{* *}$ & $0.27^{* * *}$ & & $0.18^{* *}$ & $0.16^{*}$ & $0.25^{* * *}$ \\
& $(3.11)$ & $(2.23)$ & $(2.80)$ & & $(2.49)$ & $(1.92)$ & $(2.89)$ \\
Marginal effects (at means) & 1.69 & 1.49 & 1.83 & & 1.22 & 1.08 & 1.69 \\
& & & & & & & \\
2nd order polynomial & Yes & Yes & Yes & & Yes & Yes & Yes \\
Firm level controls & No & No & No & & No & No & No \\
Firm fixed effects & Yes & No & No & & Yes & No & No \\
Industry fixed effects & No & Yes & Yes & & No & Yes & Yes \\
Year fixed effects & Yes & Yes & Yes & & Yes & Yes & Yes \\
$R^{2}$ & 0.235 & 0.144 & 0.367 & & 0.268 & 0.141 & 0.304 \\
Number of observations & 720 & 498 & 720 & & 744 & 553 & 744 \\
Number of firms & 244 & 229 & 244 & & 235 & 223 & 235 \\
\hline
\end{tabular}




\section{Table IA.16: Regression of Fraction of Independent Directors}

This table presents estimates of firm fixed effects, first differences and ordinary least squares (OLS) panel regressions of the logarithm of the ratio of the number of independent directors to the number of non-independent directors (Panel A) and the ratio of the number of independent directors to board size (Panel B). Covenant violation is a dummy variable that takes a value of one if the firm violates at least one out of four covenants (current ratio, net worth, tangible net worth, and debt-to-EBITDA) during the year in at least one quarter. The firm-level control variables are firm size (log), leverage, firm age (log), number of segments (log), market-to-book $(\log ), \mathrm{R} \& \mathrm{D}$, stock return volatility, free cash flow, return on assets, governance index, CEO ownership, and CEO tenure. All explanatory variables are lagged two years. The sample consists of annual observations on Investor Responsibility Research Center (IRRC) non-financial firms from 1994 to 2008 for which syndicated loans data are available from DealScan. The sample includes only those observations in which the absolute value of the relative binding distance to the covenant threshold is less than the bandwidth $(h=0.4)$. Refer to Table A1 in the Appendix for variable definitions. Robust $t$-statistics adjusted for firm-level clustering are in parentheses. $*, * *, * * *$ indicates significance at the $10 \%, 5 \%$, and $1 \%$ levels.

Panel A: Ratio of Independent Directors to Non-Independent Directors

\begin{tabular}{|c|c|c|c|c|c|c|}
\hline & \multicolumn{2}{|c|}{ Firm fixed effects } & \multicolumn{2}{|c|}{ First differences } & \multicolumn{2}{|c|}{ OLS } \\
\hline & (1) & $(2)$ & $(3)$ & (4) & $(5)$ & (6) \\
\hline Covenant violation & $0.44^{* * *}$ & $0.46^{* * *}$ & $0.49^{* *}$ & $0.46^{* *}$ & $0.44^{* *}$ & $0.32^{*}$ \\
\hline & $(3.19)$ & $(3.30)$ & $(2.59)$ & $(2.52)$ & $(2.22)$ & $(1.78)$ \\
\hline Marginal effects (at mean) & 1.52 & 1.59 & 1.69 & 1.59 & 1.52 & 1.11 \\
\hline 2nd order polynomial & Yes & Yes & Yes & Yes & Yes & Yes \\
\hline Firm level controls & No & Yes & No & Yes & No & Yes \\
\hline Firm fixed effects & Yes & Yes & No & No & No & No \\
\hline Industry fixed effects & No & No & Yes & Yes & Yes & Yes \\
\hline Year fixed effects & Yes & Yes & Yes & Yes & Yes & Yes \\
\hline$R^{2}$ & 0.252 & 0.304 & 0.150 & 0.165 & 0.376 & 0.501 \\
\hline Number of observations & 665 & 665 & 472 & 472 & 665 & 665 \\
\hline Number of firms & 222 & 222 & 214 & 214 & 222 & 222 \\
\hline
\end{tabular}

Panel B: Ratio of Independent Directors to Board Size

\begin{tabular}{|c|c|c|c|c|c|c|}
\hline & \multicolumn{2}{|c|}{ Firm fixed effects } & \multicolumn{2}{|c|}{ First differences } & \multicolumn{2}{|c|}{$\overline{\text { OLS }}$} \\
\hline & (1) & $(2)$ & $(3)$ & (4) & $(5)$ & (6) \\
\hline Covenant violation & $0.16^{* * *}$ & $0.17^{* * *}$ & $0.16^{* *}$ & $0.15^{* *}$ & $0.18^{* *}$ & $0.13^{*}$ \\
\hline & $(2.97)$ & $(3.21)$ & $(2.24)$ & $(2.11)$ & $(2.39)$ & $(1.96)$ \\
\hline Marginal effects (at mean) & 0.11 & 0.12 & 0.11 & 0.10 & 0.13 & 0.09 \\
\hline 2nd order polynomial & Yes & Yes & Yes & Yes & Yes & Yes \\
\hline Firm level controls & No & Yes & No & Yes & No & Yes \\
\hline Firm fixed effects & Yes & Yes & No & No & No & No \\
\hline Industry fixed effects & No & No & Yes & Yes & Yes & Yes \\
\hline Year fixed effects & Yes & Yes & Yes & Yes & Yes & Yes \\
\hline$R^{2}$ & 0.215 & 0.294 & 0.151 & 0.171 & 0.344 & 0.483 \\
\hline Number of observations & 665 & 665 & 472 & 472 & 665 & 665 \\
\hline Number of firms & 222 & 222 & 214 & 214 & 222 & 222 \\
\hline
\end{tabular}




\section{Table IA.17: Regression of Number of Independent Directors - Al- ternative Lags}

This table presents estimates of firm fixed effects, first differences and ordinary least squares (OLS) panel regressions of the logarithm of the number of independent directors. Covenant violation is a dummy variable that takes a value of one if the firm violates at least one out of four covenants (current ratio, net worth, tangible net worth, and debt-to EBITDA) during the year in at least one quarter. All explanatory variables are lagged one year in columns (1)-(3) and three years in columns (4)-(6). The sample consists of annual observations on Investor Responsibility Research Center (IRRC) non-financial firms from 1994 to 2008 for which syndicated loans data are available from DealScan. The sample includes only those observations in which the absolute value of the relative binding distance to the covenant threshold is less than the bandwidth $(h=0.4)$. Refer to Table A1 in the Appendix for variable definitions. Robust $t$-statistics adjusted for firm-level clustering are in parentheses. $* * *, * * *$ indicates significance at the $10 \%, 5 \%$, and $1 \%$ levels.

\begin{tabular}{lcccccccc}
\hline & \multicolumn{3}{c}{ One year lag } & & \multicolumn{3}{c}{ Three years lag } \\
\cline { 2 - 3 } & Firm FE & First diff. & OLS & & Firm FE & First diff. & OLS \\
& $(1)$ & $(2)$ & & $(3)$ & & $(4)$ & $(5)$ & $(6)$ \\
\hline Covenant violation & 0.04 & $0.13^{* *}$ & & $0.17^{* *}$ & & $0.18^{* *}$ & 0.12 & $0.26^{* * *}$ \\
& $(0.67)$ & $(2.20)$ & $(2.07)$ & & $(2.52)$ & $(0.99)$ & $(2.81)$ \\
Marginal effects (at mean) & 0.26 & 0.83 & 1.09 & & 1.15 & 0.77 & 1.66 \\
& & & & & & & & \\
2nd order polynomial & Yes & Yes & Yes & & Yes & Yes & Yes \\
Firm fixed effects & Yes & No & No & & Yes & No & No \\
Industry fixed effects & No & Yes & Yes & & No & Yes & Yes \\
Year fixed effects & Yes & Yes & Yes & & Yes & Yes & Yes \\
$R^{2}$ & 0.252 & 0.100 & 0.315 & & 0.153 & 0.166 & 0.337 \\
Number of observations & 743 & 547 & 743 & & 535 & 373 & 535 \\
Number of firms & 246 & 235 & 246 & & 181 & 173 & 181 \\
\hline
\end{tabular}




\section{Table IA.18: Regression of Number of Independent Directors - Calendar Year}

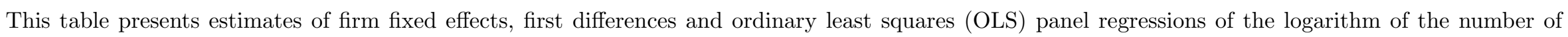

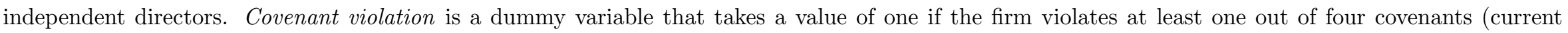

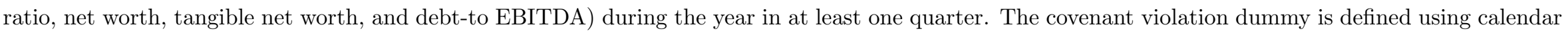

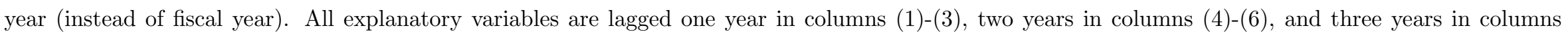

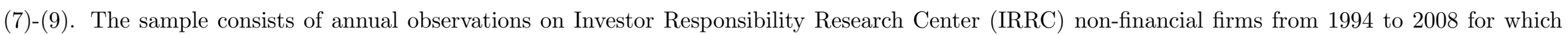

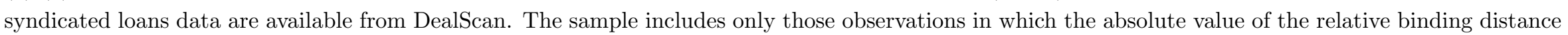

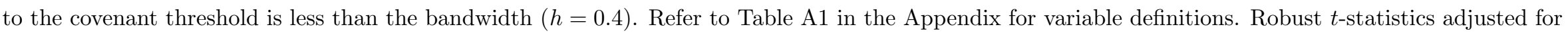
firm-level clustering are in parentheses. $*, * *, * * *$ indicates significance at the $10 \%, 5 \%$, and $1 \%$ levels.

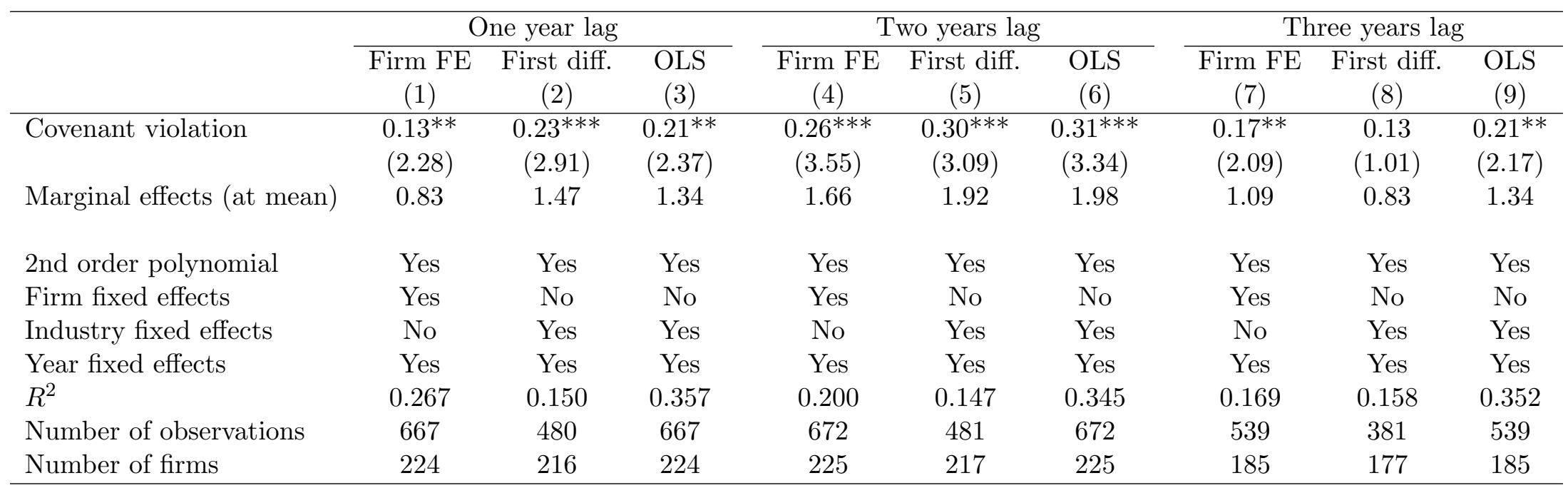




\section{Table IA.19: Regression of Number of Independent Directors - Con- trolling for Stock Return}

This table presents estimates of firm fixed effects, first differences and ordinary least squares (OLS) panel regressions of the logarithm of the ratio of the number of independent directors to the number of non-independent directors (Panel A) and the ratio of the number of independent directors to board size (Panel B). Covenant violation is a dummy variable that takes a value of one if the firm violates at least one out of four covenants (current ratio, net worth, tangible net worth, and debt-to-EBITDA) during the year in at least one quarter. The firm-level control variables are firm size (log), leverage, firm age (log), number of segments (log), market-tobook (log), stock return, R\&D, stock return volatility, free cash flow, return on assets, governance index, CEO ownership, and CEO tenure. All explanatory variables are lagged two years. The sample consists of annual observations on Investor Responsibility Research Center (IRRC) non-financial firms from 1994 to 2008 for which syndicated loans data are available from DealScan. The sample includes only those observations in which the absolute value of the relative binding distance to the covenant threshold is less than the bandwidth $(h=0.4)$. Refer to Table A1 in the Appendix for variable definitions. Robust $t$-statistics adjusted for firm-level clustering are in parentheses. ${ }^{*},{ }^{* *},{ }^{* * *}$ indicates significance at the $10 \%, 5 \%$, and $1 \%$ levels.

\begin{tabular}{|c|c|c|c|c|c|c|}
\hline & \multicolumn{2}{|c|}{ Firm fixed effects } & \multicolumn{2}{|c|}{ First differences } & \multicolumn{2}{|c|}{ OLS } \\
\hline & (1) & $(2)$ & $(3)$ & (4) & $(5)$ & (6) \\
\hline Covenant violation & $\begin{array}{c}0.24^{* * *} \\
(3.47)\end{array}$ & $\begin{array}{c}0.25^{* * *} \\
(3.66)\end{array}$ & $\begin{array}{c}0.31^{* * *} \\
(3.40)\end{array}$ & $\begin{array}{c}0.28^{* * *} \\
(3.23)\end{array}$ & $\begin{array}{c}0.32^{* * *} \\
(3.34)\end{array}$ & $\begin{array}{c}0.23^{* * *} \\
(2.67)\end{array}$ \\
\hline Marginal effects (at mean) & 1.53 & 1.60 & 1.98 & 1.79 & 2.04 & 1.47 \\
\hline 2nd order polynomial & Yes & Yes & Yes & Yes & Yes & Yes \\
\hline Firm level controls & No & Yes & No & Yes & No & Yes \\
\hline Firm fixed effects & Yes & Yes & No & No & No & No \\
\hline Industry fixed effects & No & No & Yes & Yes & Yes & Yes \\
\hline Year fixed effects & Yes & Yes & Yes & Yes & Yes & Yes \\
\hline$R^{2}$ & 0.177 & 0.251 & 0.138 & 0.169 & 0.302 & 0.499 \\
\hline Number of observations & 662 & 662 & 470 & 470 & 662 & 662 \\
\hline Number of firms & 221 & 221 & 213 & 213 & 221 & 221 \\
\hline
\end{tabular}




\section{Table IA.20: Regression of Number of Independent Directors - An- nual Binding Distance}

This table presents estimates of firm fixed effects, first differences and ordinary least squares (OLS) panel regressions of the logarithm of the number of independent directors. Covenant violation is a dummy variable that takes a value of one if the firm violates at least one out of four covenants (current ratio, net worth, tangible net worth, and debt-to-EBITDA) during the year in at least one quarter. The firm-level control variables are firm size (log), leverage, firm age (log), number of segments (log), market-to-book (log), R\&D, stock return volatility, free cash flow, return on assets, governance index, CEO ownership, and CEO tenure. All explanatory variables are lagged two years. The sample consists of annual observations on Investor Responsibility Research Center (IRRC) non-financial firms from 1994 to 2008 for which syndicated loans data are available from DealScan. Panel A includes only those observations in which the absolute value of the relative annual binding distance to the covenant threshold is less than the bandwidth $(h=0.3)$. Panel B includes only those observations in which the absolute value of the relative annual binding distance to the covenant threshold is less than the bandwidth $(h=0.2)$. Refer to Table A1 in the Appendix for variable definitions. Robust $t$-statistics adjusted for firm-level clustering are in parentheses. ${ }^{*},{ }^{* *}, * * *$ indicates significance at the $10 \%, 5 \%$, and $1 \%$ levels.

Panel A: Bandwidth $h=0.3$

\begin{tabular}{|c|c|c|c|c|c|c|}
\hline & \multicolumn{2}{|c|}{ Firm fixed effects } & \multicolumn{2}{|c|}{ First differences } & \multicolumn{2}{|c|}{ OLS } \\
\hline & $(1)$ & $(2)$ & $(3)$ & $(4)$ & $(5)$ & $(6)$ \\
\hline Covenant violation & $\begin{array}{c}0.19^{* * *} \\
(3.62)\end{array}$ & $\begin{array}{c}0.20^{* * *} \\
(3.93)\end{array}$ & $\begin{array}{c}0.22^{* * *} \\
(2.63)\end{array}$ & $\begin{array}{c}0.23^{* * *} \\
(2.85)\end{array}$ & $\begin{array}{c}0.18^{* *} \\
(2.19)\end{array}$ & $\begin{array}{c}0.14^{* *} \\
(2.06)\end{array}$ \\
\hline 2nd order polynomial & Yes & Yes & Yes & Yes & Yes & Yes \\
\hline Firm level controls & No & Yes & No & Yes & No & Yes \\
\hline Firm fixed effects & Yes & Yes & No & No & No & No \\
\hline Industry fixed effects & No & No & Yes & Yes & Yes & Yes \\
\hline Year fixed effects & Yes & Yes & Yes & Yes & Yes & Yes \\
\hline$R^{2}$ & 0.218 & 0.277 & 0.129 & 0.167 & 0.278 & 0.455 \\
\hline Number of observations & 872 & 872 & 637 & 637 & 872 & 872 \\
\hline Number of firms & 268 & 268 & 261 & 261 & 268 & 268 \\
\hline
\end{tabular}

Panel B: Bandwidth $h=0.2$

\begin{tabular}{|c|c|c|c|c|c|c|}
\hline & \multicolumn{2}{|c|}{ Firm fixed effects } & \multicolumn{2}{|c|}{ First differences } & \multicolumn{2}{|c|}{ OLS } \\
\hline & (1) & (2) & $(3)$ & (4) & $(5)$ & (6) \\
\hline Covenant violation & $\begin{array}{c}0.22^{* * *} \\
(3.13)\end{array}$ & $\begin{array}{c}0.26^{* * *} \\
(3.56)\end{array}$ & $\begin{array}{l}0.27^{* *} \\
(2.24)\end{array}$ & $\begin{array}{l}0.24^{* *} \\
(2.08)\end{array}$ & $\begin{array}{l}0.19^{* *} \\
(2.08)\end{array}$ & $\begin{array}{c}0.13 \\
(1.63)\end{array}$ \\
\hline 2nd order polynomial & Yes & Yes & Yes & Yes & Yes & Yes \\
\hline Firm level controls & No & Yes & No & Yes & No & Yes \\
\hline Firm fixed effects & Yes & Yes & No & No & No & No \\
\hline Industry fixed effects & No & No & Yes & Yes & Yes & Yes \\
\hline Year fixed effects & Yes & Yes & Yes & Yes & Yes & Yes \\
\hline$R^{2}$ & 0.176 & 0.243 & 0.160 & 0.194 & 0.348 & 0.533 \\
\hline Number of observations & 473 & 473 & 348 & 348 & 473 & 473 \\
\hline Number of firms & 166 & 166 & 164 & 164 & 166 & 166 \\
\hline
\end{tabular}




\section{Table IA.21: Regression of Number of Connected Directors - Lead Arrangers and Other Participants}

This table presents estimates of firm fixed effects, first differences and ordinary least squares (OLS) panel regressions of the logarithm of one plus the number of connected directors. Connected directors are those that have a board or non-board position in another firm with outstanding loans that have at least one bank in common with the firm's current banks. The sample of banks includes lead arrangers in columns (1)-(3) and other participants in the loan syndicate in columns (4)-(6). Covenant violation is a dummy variable that takes a value of one if the firm violates at least one out of four covenants (current ratio, net worth, tangible net worth, and debt-to EBITDA) during the year in at least one quarter. The sample consists of annual observations on Investor Responsibility Research Center (IRRC) non-financial firms from 1994 to 2008 for which syndicated loans data are available from DealScan. The sample includes only those observations in which the absolute value of the relative binding distance to the covenant threshold is less than the bandwidth $(h=0.4)$. Refer to Table A1 in the Appendix for variable definitions. Robust $t$-statistics adjusted for firm-level clustering are in parentheses. ${ }^{*}, * *, * * *$ indicates significance at the $10 \%, 5 \%$, and $1 \%$ levels.

\begin{tabular}{|c|c|c|c|c|c|c|}
\hline & \multicolumn{3}{|c|}{$\begin{array}{c}\text { Number of connected directors } \\
\text { lead arrangers }\end{array}$} & \multicolumn{3}{|c|}{$\begin{array}{l}\text { Number of connected directors } \\
\text { other participants }\end{array}$} \\
\hline & $\begin{array}{l}\text { Firm FE } \\
\text { (1) }\end{array}$ & $\begin{array}{l}\text { First diff. } \\
\quad(2)\end{array}$ & $\begin{array}{l}\text { OLS } \\
(3)\end{array}$ & $\begin{array}{l}\text { Firm FE } \\
\text { (4) }\end{array}$ & $\begin{array}{l}\text { First diff. } \\
\text { (5) }\end{array}$ & $\begin{array}{l}\text { OLS } \\
(6)\end{array}$ \\
\hline Covenant violation & $\begin{array}{c}0.10 \\
(1.01)\end{array}$ & $\begin{array}{l}0.25^{*} \\
(1.66)\end{array}$ & $\begin{array}{l}0.25^{*} \\
(1.70)\end{array}$ & $\begin{array}{l}0.15^{* *} \\
(1.99)\end{array}$ & $\begin{array}{l}0.24^{*} \\
(1.81)\end{array}$ & $\begin{array}{l}0.17^{* *} \\
(2.15)\end{array}$ \\
\hline Marginal effects (at mean) & 0.38 & 0.94 & 0.94 & 0.21 & 0.33 & 0.23 \\
\hline 2nd order polynomial & Yes & Yes & Yes & Yes & Yes & Yes \\
\hline Firm fixed effects & Yes & No & No & Yes & No & No \\
\hline Industry fixed effects & No & Yes & Yes & No & Yes & Yes \\
\hline Year fixed effects & Yes & Yes & Yes & Yes & Yes & Yes \\
\hline$R^{2}$ & 0.069 & 0.149 & 0.261 & 0.065 & 0.144 & 0.159 \\
\hline Number of observations & 623 & 439 & 623 & 623 & 439 & 623 \\
\hline Number of firms & 207 & 199 & 207 & 207 & 199 & 207 \\
\hline
\end{tabular}




\section{Table IA.22: Characteristics of Independent Directors Appointed af- ter Covenant Violations}

This table reports sample averages of the characteristics of new independent directors appointed in the two years after a firm first violates a covenant and a matched control group of independent directors. To construct the control group, a new director is matched to a randomly-chosen independent director in the same firm. In Panel A the control group includes independent directors retained by the firm for at least two years after the first violation. In Panel B the control group includes independent directors who are members of the board in the two years before the first violation and remained in the board for at least two years after the first violation. Director characteristics are from the BoardEx database. Refer to Table A1 in the Appendix for variable definitions.

Panel A: Control Group - Directors who remained in the board after violation

\begin{tabular}{lccccc}
\hline & $\begin{array}{c}\text { New } \\
\text { directors }\end{array}$ & $\begin{array}{c}\text { Control } \\
\text { group }\end{array}$ & Difference & $t$-statistic & $\begin{array}{c}\text { Number } \\
\text { of obs. }\end{array}$ \\
\hline Male & 0.92 & 0.88 & 0.04 & 1.41 & 223 \\
Age & 55.97 & 60.20 & -4.23 & -5.97 & 223 \\
MBA & 0.20 & 0.13 & 0.07 & 1.90 & 223 \\
Financial education & 0.26 & 0.14 & 0.12 & 3.18 & 223 \\
Audit or finance committee & 0.59 & 0.63 & -0.04 & -0.77 & 223 \\
Past audit or finance committee & 0.47 & 0.40 & 0.07 & 1.40 & 223 \\
Past financial role & 0.20 & 0.11 & 0.09 & 2.42 & 223 \\
Financial firm connection & 0.22 & 0.22 & 0.00 & -0.12 & 223 \\
Financial firm board member & 0.15 & 0.19 & -0.04 & -1.00 & 223 \\
Number of board positions & 1.96 & 2.20 & -0.24 & -1.18 & 223 \\
Number of past board positions & 1.23 & 1.57 & -0.34 & -1.96 & 223 \\
Bank connection & 0.71 & 0.50 & 0.21 & 4.58 & 171 \\
Bank connection - violation & 0.65 & 0.48 & 0.17 & 3.56 & 171 \\
\hline
\end{tabular}

Panel B: Control Group - Directors who joined the board before violation and remained in the board

\begin{tabular}{lccccc}
\hline & $\begin{array}{c}\text { New } \\
\text { directors }\end{array}$ & $\begin{array}{c}\text { Control } \\
\text { group }\end{array}$ & Difference & $t$-statistic & $\begin{array}{c}\text { Number } \\
\text { of obs. }\end{array}$ \\
\hline Male & 0.92 & 0.87 & 0.05 & 1.65 & 226 \\
Age & 55.75 & 59.27 & -3.52 & -5.01 & 226 \\
MBA & 0.20 & 0.12 & 0.08 & 2.46 & 226 \\
Financial education & 0.27 & 0.17 & 0.11 & 2.83 & 226 \\
Audit or finance committee & 0.59 & 0.59 & 0.00 & 0.00 & 226 \\
Past audit or finance committee & 0.46 & 0.32 & 0.14 & 2.94 & 226 \\
Past financial role & 0.21 & 0.12 & 0.09 & 2.45 & 226 \\
Financial firm connection & 0.23 & 0.22 & 0.01 & 0.24 & 226 \\
Financial firm board member & 0.16 & 0.19 & -0.03 & -0.75 & 226 \\
Number of board positions & 2.00 & 2.46 & -0.46 & -1.60 & 226 \\
Number of past board positions & 1.27 & 1.35 & -0.08 & -0.48 & 226 \\
Bank connection & 0.72 & 0.40 & 0.32 & 6.31 & 174 \\
Bank connection - violation & 0.65 & 0.33 & 0.32 & 6.31 & 174 \\
\hline
\end{tabular}




\section{Table IA.23: Regression of Firm Policies - Collapsed Observations}

This table presents estimates of regressions of investment, financing, payout, volatility and CEO compensation around the time of covenant violations. A covenant violation occurs if the firm violates at least one out of four covenants (current ratio, net worth, tangible net worth, and debt-to-EBITDA) during the year in at least one quarter. The firm-level control variable is firm size (log). New appointment is a (treatment group) dummy variable that takes a value of one if there is an increase in the number of independent directors between year 0 and year 2. After is a dummy variable that takes a value of one in the post-violation period. Panel A presents estimates in which the dependent variable is capital expenditures (scaled by lagged property, plant and equipment), net debt issues, net equity issues, SEO proceeds, changes in dividends (all scaled by lagged total assets), and changes in the standard deviation (annualized) of return on assets (ROA) over the last eight quarters. Panel B presents estimates in which the dependent variable is the logarithm of CEO total pay, salary, bonus, value of option grants (grant-date Black-Scholes value) or value of restricted stock grants (grant-date fair value). The sample consists of annual observations on Investor Responsibility Research Center (IRRC) non-financial firms from 1994 to 2008 for which syndicated loans data are available from DealScan. The data is collapsed into two periods: before violation (years -3, -2, and -1) and after violation (years 2, 3, and 4). Refer to Table A1 in the Appendix for variable definitions. Robust $t$-statistics adjusted for firm-level clustering are in parentheses. $* * *, * * *$ indicates significance at the $10 \%, 5 \%$, and $1 \%$ levels.

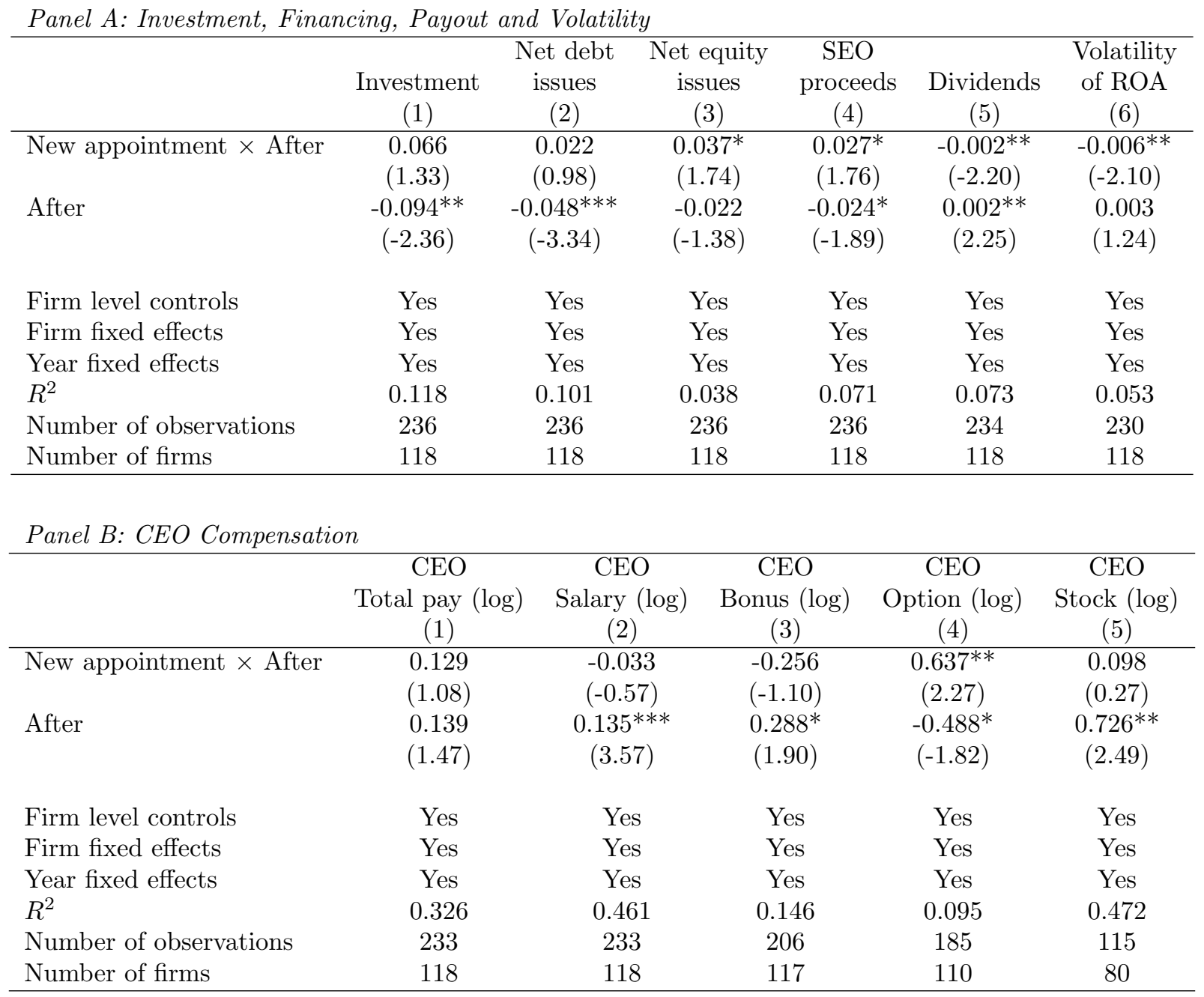




\section{Table IA.24: Regression of Number of Independent Directors - Cross-Sectional Variation}

This table presents estimates of firm fixed effects panel regressions of the logarithm of the number of independent directors. Covenant violation is a dummy variable that takes a value of one if the firm violates at least one out of four covenants (current ratio, net worth, tangible net worth, and debt-to-EBITDA) during the year in at least one quarter. The specification interacts an indicator for a group of firms with the covenant violation dummy and control variables (firm size, leverage, firm age, number of segments, market-to-book, R\&D, stock return volatility, free cash flow, return on assets, governance index, CEO ownership, and CEO tenure). Panel A reports the estimates for the lending relationship proxies. The past loans $\geq 2$ group includes firms that had at least two historical lending relationships (only term loans) with the lead arranger in the current loan syndicate and the past loans $<2$ group includes all other cases. The past loans $\geq 5$ group includes firms that had at least five historical lending relationships (all loans) with the lead arranger in current loan syndicate and the past loans $<5$ group includes all other cases. The rated firm group consists of firms with a $\mathrm{S} \& \mathrm{P}$ credit rating and the unrated firm group includes all other cases. Panel B reports the estimates for the loan repayment and covenant slack proxies. The large loan and small loan groups include firms with ratio of loan amount (at origination) to assets above and below the median. The short maturity and long maturity loan groups include firms with residual loan maturity below and above the median. The high binding distance and low binding distance groups include firms with binding distance at origination above and below the median. The high tightness and low tightness groups include firms with tightness at origination above and below the median. All explanatory variables are lagged two years. The sample consists of annual observations on Investor Responsibility Research Center (IRRC) non-financial firms from 1994 to 2008 for which syndicated loans data are available from DealScan. The sample includes only those observations in which the absolute value of the relative binding distance to the covenant threshold is less than the bandwidth $(h=0.4)$. Refer to Table A1 in the Appendix for variable definitions. Robust $t$-statistics adjusted for firm-level clustering are in parentheses. $*, * *, * * *$ indicates significance at the $10 \%, 5 \%$, and $1 \%$ levels.

\begin{tabular}{|c|c|c|c|c|c|c|}
\hline & (1) & $(2)$ & (3) & (4) & (5) & (6) \\
\hline Past loans $\geq 2$ & $\begin{array}{c}0.32^{* * *} \\
(4.41)\end{array}$ & $\begin{array}{c}0.30^{* * *} \\
(3.43)\end{array}$ & & & & \\
\hline Past loans $<2$ & $\begin{array}{c}0.13 \\
(1.40)\end{array}$ & $\begin{array}{c}0.17 \\
(1.49)\end{array}$ & & & & \\
\hline Past loans $\geq 5$ & & & $\begin{array}{c}0.30^{* * *} \\
(3.15)\end{array}$ & $\begin{array}{c}0.25^{* * *} \\
(2.87)\end{array}$ & & \\
\hline Past loans $<5$ & & & $\begin{array}{c}0.18^{* *} \\
(2.25)\end{array}$ & $\begin{array}{c}0.22^{* *} \\
(2.23)\end{array}$ & & \\
\hline Unrated firm & & & & & $\begin{array}{c}0.26^{* *} \\
(2.27)\end{array}$ & $\begin{array}{c}0.39^{* * *} \\
(2.61)\end{array}$ \\
\hline Rated firm & & & & & $\begin{array}{c}0.23^{* * *} \\
(2.95)\end{array}$ & $\begin{array}{c}0.16^{* *} \\
(2.19)\end{array}$ \\
\hline 2nd order polynomial & Yes & Yes & Yes & Yes & Yes & Yes \\
\hline Firm level controls & No & Yes & No & Yes & No & Yes \\
\hline Firm fixed effects & Yes & Yes & Yes & Yes & Yes & Yes \\
\hline Year fixed effects & Yes & Yes & Yes & Yes & Yes & Yes \\
\hline$R^{2}$ & 0.204 & 0.305 & 0.199 & 0.308 & 0.188 & 0.289 \\
\hline Number of observations & 665 & 665 & 665 & 665 & 665 & 665 \\
\hline Number of firms & 222 & 222 & 222 & 222 & 222 & 222 \\
\hline
\end{tabular}


Panel B: Loan Repayment and Covenant Slack

\begin{tabular}{|c|c|c|c|c|c|c|c|c|}
\hline & $(1)$ & $(2)$ & $(3)$ & $(4)$ & $(5)$ & $(6)$ & $(7)$ & $(8)$ \\
\hline Large loan & $\begin{array}{c}0.27^{* * *} \\
(3.49)\end{array}$ & $\begin{array}{c}0.26^{* * *} \\
(2.83)\end{array}$ & & & & & & \\
\hline Small loan & $\begin{array}{c}0.10 \\
(1.07)\end{array}$ & $\begin{array}{c}0.16 \\
(1.52)\end{array}$ & & & & & & \\
\hline Short maturity & & & $\begin{array}{c}0.32^{* * *} \\
(2.98)\end{array}$ & $\begin{array}{c}0.40^{* * *} \\
(3.27)\end{array}$ & & & & \\
\hline Long maturity & & & $\begin{array}{c}0.21^{* * *} \\
(2.94)\end{array}$ & $\begin{array}{c}0.18^{* *} \\
(2.56)\end{array}$ & & & & \\
\hline High binding distance & & & & & $\begin{array}{c}0.35^{* *} \\
(2.15)\end{array}$ & $\begin{array}{c}0.38^{* *} \\
(2.21)\end{array}$ & & \\
\hline Low binding distance & & & & & $\begin{array}{c}0.23^{* * *} \\
(3.24)\end{array}$ & $\begin{array}{c}0.22^{* * *} \\
(3.09)\end{array}$ & & \\
\hline High tightness & & & & & & & $\begin{array}{c}0.23^{* *} \\
(2.13)\end{array}$ & $\begin{array}{c}0.33^{* *} \\
(2.44)\end{array}$ \\
\hline Low tightness & & & & & & & $\begin{array}{c}0.19^{* * *} \\
(2.63)\end{array}$ & $\begin{array}{c}0.13^{* *} \\
(2.07)\end{array}$ \\
\hline 2nd order polynomial & Yes & Yes & Yes & Yes & Yes & Yes & Yes & Yes \\
\hline Firm level controls & No & Yes & No & Yes & No & Yes & No & Yes \\
\hline Firm fixed effects & Yes & Yes & Yes & Yes & Yes & Yes & Yes & Yes \\
\hline Year fixed effects & Yes & Yes & Yes & Yes & Yes & Yes & Yes & Yes \\
\hline$R^{2}$ & 0.179 & 0.275 & 0.199 & 0.286 & 0.185 & 0.285 & 0.207 & 0.338 \\
\hline Number of observations & 658 & 658 & 665 & 665 & 665 & 665 & 665 & 665 \\
\hline Number of firms & 222 & 222 & 222 & 222 & 222 & 222 & 222 & 222 \\
\hline
\end{tabular}




\section{Figure IA.1: Number of Non-Independent Directors and Binding Distance to Covenant Threshold}

This figure shows nonparametric regression estimates of number of non-independent directors (two years after violation) on the relative binding distance to the covenant threshold. A covenant violation occurs if the firm violates at least one out of four covenants (current ratio, net worth, tangible net worth, and debt-to-EBITDA) during the year in at least one quarter. Panel A presents estimates using all covenant violations, and Panel B presents estimates using only the first covenant violation for each firm. The sample consists of annual observations on Investor Responsibility Research Center (IRRC) non-financial firms from 1994 to 2008 for which syndicated loans data are available from DealScan.

Panel A: All Violations

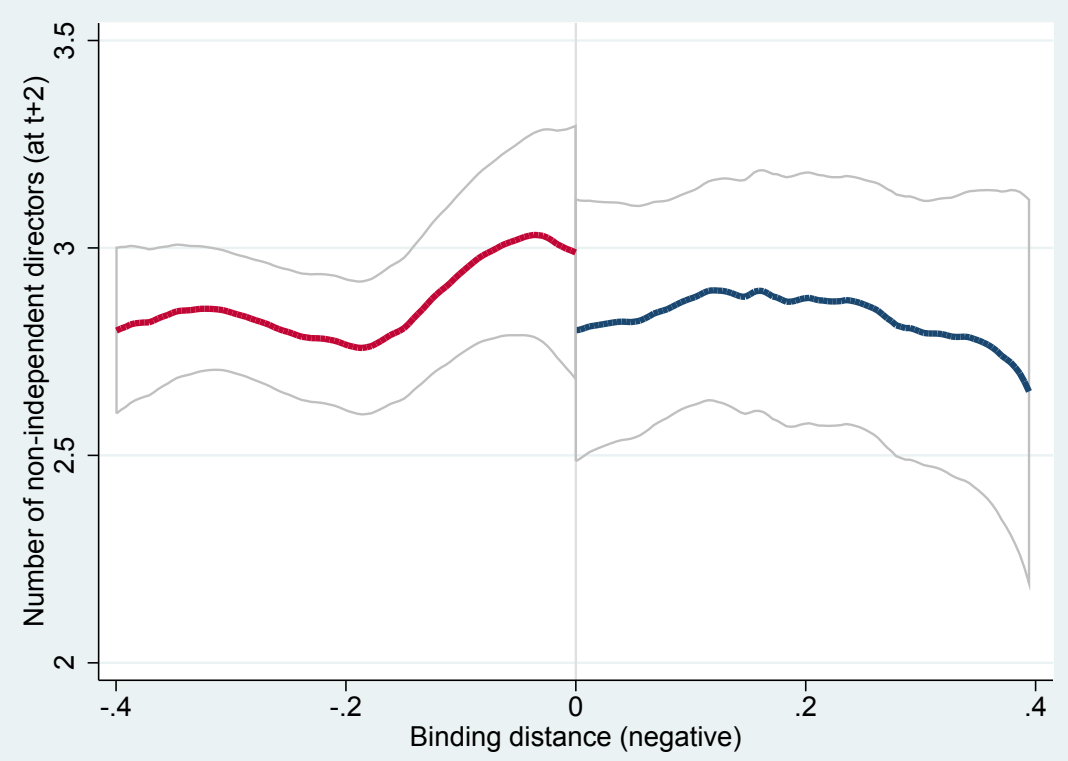

Panel B: First Violations

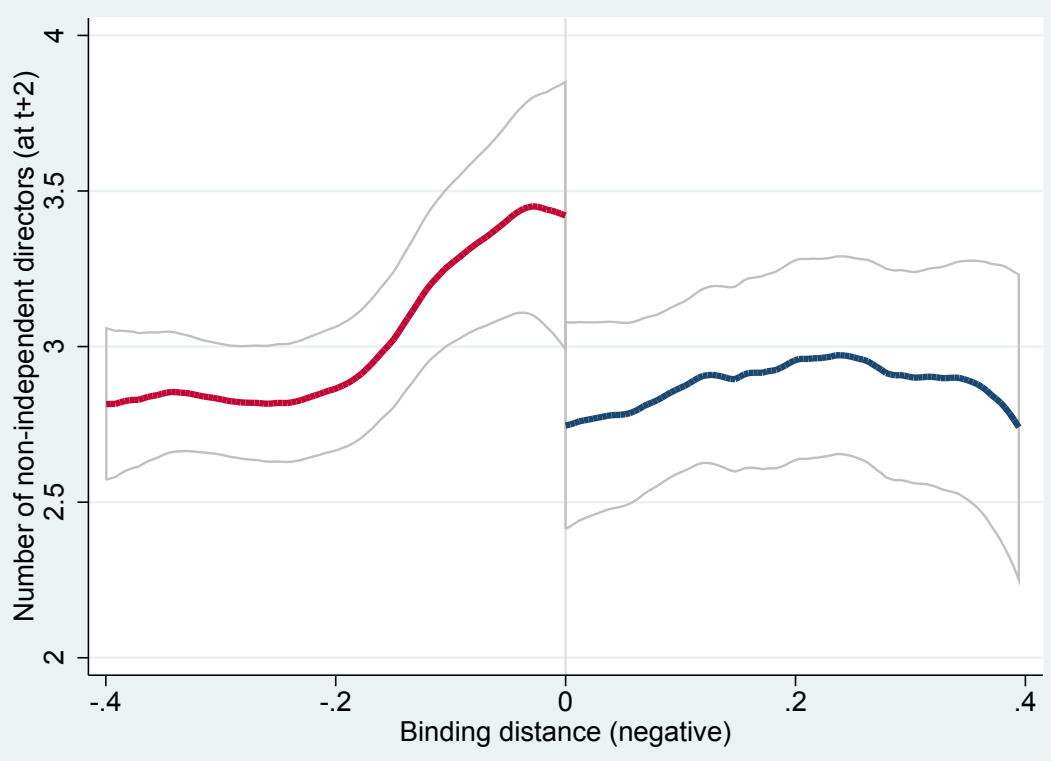




\section{Figure IA.2: Ratio of Independent to Non-Independent Directors - SEC Sample}

This figure shows the cross-sectional average and $95 \%$ confidence interval of the ratio of independent to nonindependent directors in the four years before and after a covenant violation. A covenant violation occurs if the firm reports a financial covenant violation in SEC's 10-Q or 10-K filings. The sample consists of annual observations on Investor Responsibility Research Center (IRRC) non-financial firms from 1994 to 2008.

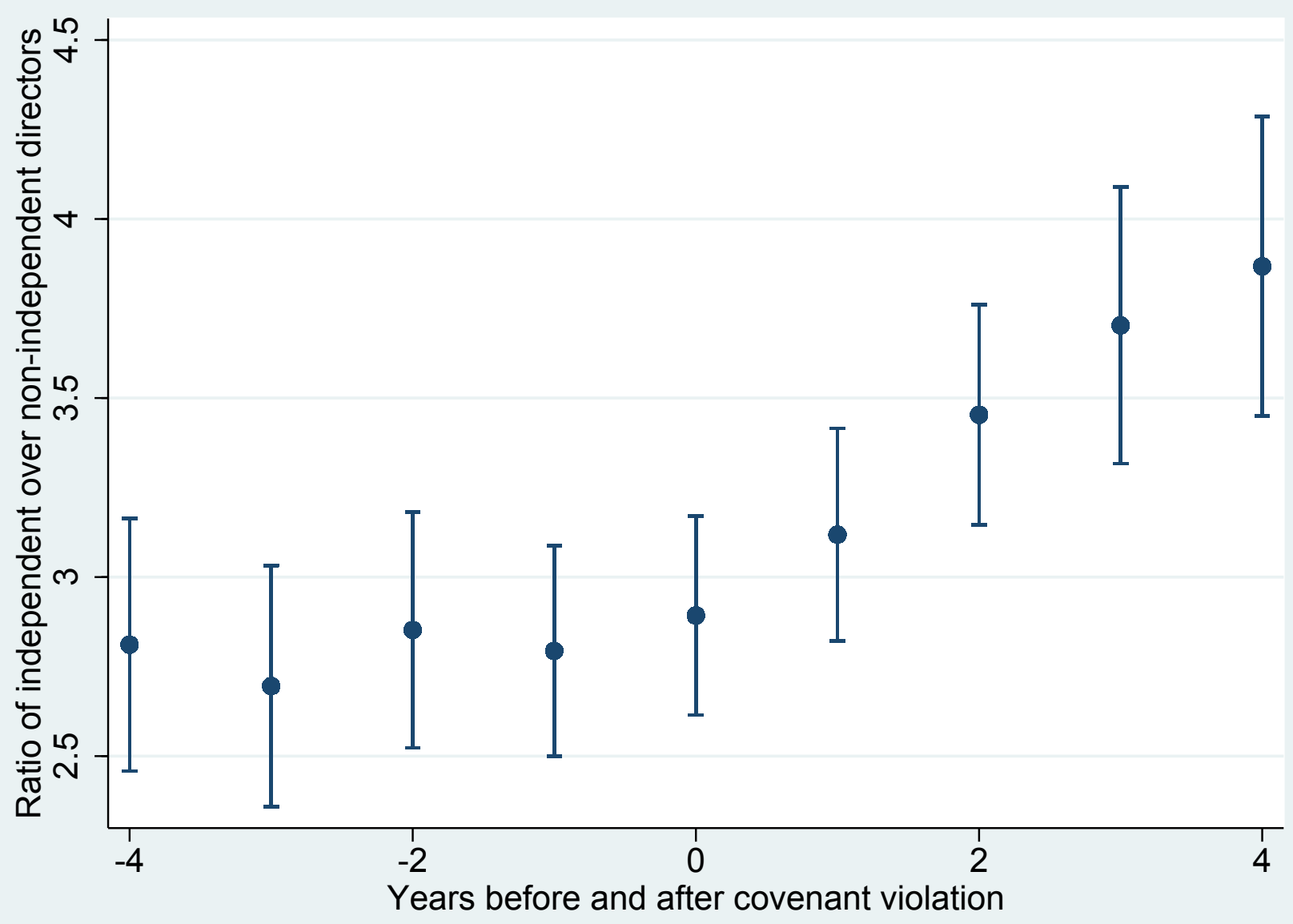




\section{References}

Demiroglu, Cem, and Christopher James, 2010, The information content of bank loan covenants, Review of Financial Studies 23, 3700-3737.

Nini, Greg, David Smith, and Amir Sufi, 2012, Creditor control rights, corporate governance, and firm value, Review of Financial Studies 25, 1713-1761. 


\section{about ECGI}

The European Corporate Governance Institute has been established to improve corporate governance through fostering independent scientific research and related activities.

The ECGI will produce and disseminate high quality research while remaining close to the concerns and interests of corporate, financial and public policy makers. It will draw on the expertise of scholars from numerous countries and bring together a critical mass of expertise and interest to bear on this important subject.

The views expressed in this working paper are those of the authors, not those of the ECGI or its members. 


\section{ECGI Working Paper Series in Finance}

\section{Editorial Board}

Editor

Consulting Editors

Editorial Assistants : Tamas Barko, University of Mannheim

Ulrich Keesen, University of Mannheim

Mengqiao Du, University of Mannheim 


\section{Electronic Access to the Working Paper Series}

The full set of ECGI working papers can be accessed through the Institute's Web-site (www.ecgi.org/wp) or SSRN:

Finance Paper Series http://www.ssrn.com/link/ECGI-Finance.html

Law Paper Series http://www.ssrn.com/link/ECGI-Law.html 